\title{
Articles
}

\section{A Property Right in Self-Expression: Equality and Individualism in the Natural Law of Intellectual Property*}

\author{
Wendy J. Gordon ${ }^{\dagger}$
}

\author{
CONTENTS
}

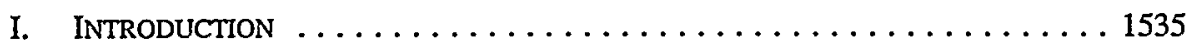

II. A NATURAL-Rights APPROACH To INTELLECTUAL PROPERTY $\ldots \ldots \ldots \ldots 1540$

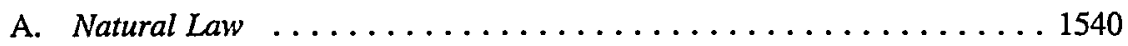

* Copyright $\odot 1993$ by Wendy J. Gordon.

$\dagger$ Professor of Law, Rutgers University School of Law-Newark.

This Article began several years ago as a rebuttal to a stimulating but recalcitrant audience at the University of Michigan. In its early stages, the piece (then called something like "Owning the Fruits of Creative Labor") benefited significantly from being presented at the N.Y.U. Law and Philosophy colloquium and the Rutgers Faculty Colloquium. I wish to thank Allan Axelrod, Richard Brandt, David Haber, Alan Hyde, Howard Latin and Patricia White, who were particularly helpful during this early revision period. After the piece achieved more or less its current form and title, useful comments were provided by participants in faculty workshops at the law schools of Boston University, Cardozo, Emory, Northwestern, and the University of Chicago. I would also like to thank the following for their valuable suggestions: Tim Brennan, Ralph Brown, Pat Croskery, Paul Garcia, Kent Greenawalt, Marci Hamilton, Heidi Hurd (and the members of her political theory class), Jim Lindgren, Jessica Litman, Henry Perritt, Geoffrey Miller, Sam Postbrief, Bob Rotstein, Pam Samuelson, Liz Stotland, Jeremy Waldron and Joan Williams. In addition I would like to express appreciation to Dean Peter Simmons for his encouragement, and to the S.I. Newhouse Faculty Research Fund of the Rutgers University School of Law-Newark, for its financial assistance. 
B. The Laborer's Claims . . . . . . . . . . . . . . . . . . . . . . 1544

1. The Harm-based Structure of Locke's Argument for Property . . . 1544

2. The Nature of Lockean Property Entitlements ... . . . . . . 1549

a. Liberty Right to Use One's Property ............. 1550

b. Power of Transfer ................... 1551

c. The Claim Right to Exclude ................. 1552

3. From Natural Property Rights to Property in Civil Society . . . . . 1554

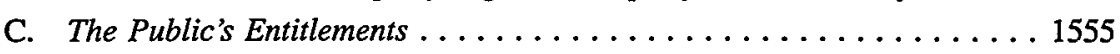

1. Importance of a Common Heritage in Maintaining

Expressive Capacity . . . . . . . . . . . . . . 1556

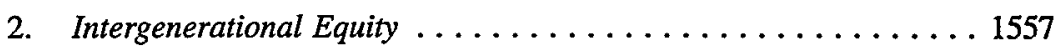

3. The Intangible Common ................. 1558

4. The Common as Property .................... 1559

D. Conflicts Between the Laborer's Claims and the Public's Entitlement in the Common: The Proviso . . . . . . . . . . . . . . . . . . 1560

1. Defining the Proviso . ................... 1562

2. The Role of the Proviso in Justifying and Limiting Property . . . 1565

3. Individualized and Nonfungible Nature of the Proviso's

Protection ............................ 1570

E. Natural-Right Rewards Other than Property: The Proviso

in an Ideal World . . . . . . . . . . . . . . . . . . . . 1572

1. Liability rule protections . . . . . . . . . . . . . 1573

2. Stowaways: Instead of a Trespass or Strict Liability Right,

Owners Might be Given a Right Actionable Only upon Proof of

Specific Intent by Defendants . . . . . . . . . . . . . . 1576

F. Congruence with Contemporary Legal Structures . . . . . . . . 1578

1. General Parallels ..................... 1578

2. Congruence with Contemporary Intellectual Property Law ..... 1581

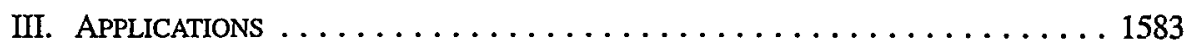

A. The "Gay Olympics" Case .................. 1583

B. Suits Against the Biographers of L. Ron Hubbard, J.D. Salinger,

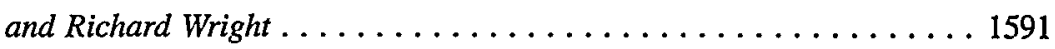

C. West Publishing Company v. Mead Data Central, Inc. . . . . . . . . 1595

D. Walt Disney v. Air Pirates and the "Pretty Woman" Case ........ 1601

E. The Pillsbury Dough Boy .................... 1605

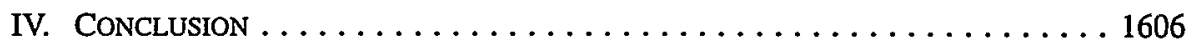




\section{INTRODUCTION}

This Article argues that a properly conceived natural-rights theory of intellectual property would provide significant protection for free speech interests. This is more than just an academic exercise. Judges have failed to use the First Amendment to provide extensive protection for free expression in intellectual property cases, in part because they mistakenly find a warrant for strong "authors' rights" in a philosophy of natural law. Natural rights theory, however, is necessarily concerned with the rights of the public as well as with the rights of those whose labors create intellectual products. When the limitations in natural law's premises are taken seriously, natural rights not only cease to be a weapon against free expression; they also become a source of affirmative protection for free speech interests.

The First Amendment stakes are high in intellectual property cases; inability to use the work of others can stifle free thought and vital interchange. For example, the licensee of the Church of Scientology brought copyright infringement suits to restrain the publication of books critical of Scientology or its founder, L. Ron Hubbard.' West Publishing enjoined Mead Data from providing LEXIS customers with jump-cites to legal opinions published in West reporters, including those West reporters containing a state's sole official case report. ${ }^{2}$ The holder of copyright in a pro-choice book sued when an antiabortion book quoted from her volume. ${ }^{3}$ One faction of Christian Scientists asserted copyright in an attempt to hinder another faction's spread of an unorthodox version of Mary Baker Eddy's writings. ${ }^{4} \mathrm{~A}$ trademark owner prevented the "Gay Olympics" from so describing itself while allowing "Special Olympics" to go its socially uncontroversial way. ${ }^{5}$ The administratrix of the estate of Martin Luther King, Jr. sued with others under the right of publicity to bar the distribution of statues of Dr. King of which they disapproved. ${ }^{6}$ And the Walt Disney Corporation, whose work has influenced

1. New Era Publications Int'l, ApS v. Henry Holt \& Co., 695 F. Supp. 1493 (S.D.N.Y. 1988), aff'd on other grounds, 873 F.2d 576 (2d Cir.), cert. denied, 110 S. Ct. 1168 (1990) (action based on passages quoted from Hubbard's published and unpublished writings); see also New Era Publications Int'l, ApS v. Carol Publishing Group, 904 F.2d 152 (2d Cir.), cert. denied, 111 S. Ct. 297 (1990) (action based on quotations from Hubbard's published writings).

2. West Publishing Co. v. Mead Data Central, 799 F.2d 1219 (8th Cir.) (preliminary injunction), cert. denied, 479 U.S. 1070 (1987).

3. Maxtone-Graham v. Burtchaell, 803 F.2d 1253 (2d Cir.), cert. denied, 481 U.S. 1059 (1987).

4. Instances discussed in United Christian Scientists v. Christian Science Bd. of Directors, 829 F.2d 1152,1156 n. 18 (D.C. Cir. 1987) (declaratory judgment holding unconstitutional a private law extending special copyright privileges to certain writings by Mary Baker Eddy).

5. San Francisco Arts \& Athletics v. United States Olympic Comm., 483 U.S. 522 (1987) (rejecting First Amendment challenge and holding property right of U.S. Olympic Committee to include power to forbid use of the word by petitioner). Ordinarily, communicative uses of trademarks are permitted by the law. See e.g., New Kids on the Block v. News America Publishing Inc., 971 F.2d 302, 306-07 (9th Cir. 1992).

6. Martin Luther King, Jr., Center for Social Change v. American Heritage Prods., 694 F.2d 674 (11th Cir. 1983). 
generations of children, employed copyright to prevent those children-now adults-from using bawdy parodies of Disney images to ridicule its viewpoints. $^{7}$

As Salman Rushdie has observed, "those who do not have power over the story that dominates their lives, power to retell it, rethink it, deconstruct it, joke about it, and change it as times change, truly are powerless, because they cannot think new thoughts." ${ }^{8}$ Yet in the foregoing and other situations," claimants tried to enforce their intellectual property rights in ways that would impermissibly inhibit others from turning the original works to their own aesthetic, cultural, and political advantage. ${ }^{10}$ In such cases, the First Amendment and doctrines such as the "fair use" privilege in copyright" provide some protection for free speech, but it is surprisingly weak. Because copyright falls under the rubric of "property," courts seem willing to overlook the most basic canons of the law of free expression. ${ }^{12}$ For example, one of the most troublesome things a judge can do under classic First Amendment

7. Walt Disney Prods. v. Air Pirates, 581 F.2d 751 (9th Cir. 1978) (Disney suit against "counter-culture" comic books portraying Mickey Mouse in compromising positions), cert. denied, 439 U.S. 1132 (1979).

8. Salman Rushdie, Excerpts from Rushdie's Address: 1,000 Days 'Trapped Inside a Metaphor,' N.Y. TIMES, Dec. 12, 1991, at B8 (excerpts from speech delivered at Columbia University).

9. See, e.g., Salinger v. Random House Inc., 811 F.2d 90 (2nd Cir.), cert. denied, 484 U.S. 890 (1987) (enjoining publication of biography that quoted from J.D. Salinger's letters without permission).

10. I do not include commercial advantage as a goal capable of outweighing creators' property rights. While authors have a valid distributional claim to some commercial reward, the public's claims examined here are premised on noncommercial interests. See Wendy J. Gordon, An Inquiry into the Merits of Copyright: The Challenges of Consistency, Consent, and Encouragement Theory, 41 STAN. L. REV. 1343, 1435-65 (1989) [hereinafter Gordon, Merits of Copyright] (arguing that, in some cases, authors' entitlement to payment should prevail against public's claim that it is entitled to the quantity and price that would have been available in a world without intellectual property rights); see also Wendy J. Gordon, On Owning Information: Intellectual Property and the Restitutionary Impulse, 78 VA. L. REv. 149 (1992) [hereinafter Gordon, On Owning Information] (corrective justice approach justifies giving authors a right-albeit conditional and defeasible - to a reward for their efforts); Wendy J. Gordon, Toward a Jurisprudence of Benefits: The Norms of Copyright and the Problem of Private Censorship, 57 U. CHI. L. REv. 1009, 103249 (1990) [hereinafter Gordon, Jurisprudence of Benefits] (reconciling Lockean and economic approaches as applied to certain entitlements of owners and the public). When the common law declines to impose liability on persons who benefit commercially from others' efforts, the reasons primarily have to do with the courts' concerns with autonomy, systemic economic costs, and harm avoidance, rather than with any disapproval of the norm that benefit-creation deserves reward. See generally Wendy J. Gordon, Of Harms and Benefits: Torts, Restitution and Intellectual Property, 21 J. LEGAL STUD. 449 (1992) [hereinafter Gordon, Of Harms and Benefits]; see also Saul Levmore, Explaining Restitution. 71 VA. L. REV. 65 (1985).

11. The fair use doctrine makes otherwise actionable copying noninfringing. The doctrine operates essentially to equip defendants with the opportunity to make general claims of justification.

Congress listed a set of nonexclusive factors that courts should consider when assessing fair use claims, including the purpose and character of the defendant's use, the proportion of the plaintiff's work that was copied, and the economic impact that the copying is likely to have on the plaintiff. 17 U.S.C. $\S 107$ (1988). The doctrine remains, however, a judicially governed rule of reason designed to relieve a defendant of liability and allow her to copy when consistent with the overall purposes of the copyright act. See generally Wendy J. Gordon, Fair Use as Market Failure: A Structural and Economic Analysis of the Betamax Case and its Predecessors, 82 CoLuM. L. REV. 1600 (1982) [hereinafter Fair Use] (using an economic model to unify fair use cases and give some precision to the notoriously open-ended doctrine).

12. For a particularly eloquent treatment of this theme see Diane L. Zimmerman, Information as Speech, Information as Goods: Some Thoughts on Marketplaces and the Bill of Rights, 33 WM. \& MARY L. REV. 665 (1992). 
jurisprudence is to enforce a "prior restraint" on speech. ${ }^{13}$ Yet in copyright cases judges routinely enjoin books prior to publication without even appearing to notice the anomaly. Similarly, in libel and related areas of tort law the Supreme Court has held that the First Amendment requires giving the defendant special privileges, ${ }^{14}$ yet no constitutional privileges are provided when suits are brought under copyright or trademark. It is supposed that as long as ideas are free for all to use, no harm to free speech can result from forbidding the copying of expression. ${ }^{15}$

Legions of commentators have deplored these developments. Lawyers, law professors, and even judges are on record pleading for the law to subject intellectual property to the same free speech principles that limit other assertions of governmental power. Some argue for recognizing an independent First Amendment defense to copyright, right of publicity, and trademark actions, while others marshal free speech principles to argue for strengthening the doctrines within intellectual property, such as fair use in copyright, which exhibit some recognition of free speech interests. ${ }^{16}$ But the courts have too often turned a deaf ear to these arguments. The incantation "property" seems sufficient to render free speech issues invisible. ${ }^{17}$

13. See Vincent Blasi, Toward a Theory of Prior Restraint: The Central Linkage, 66 MiNN. L. REV. 11, 11-12 (1981); Thomas I. Emerson, The Doctrine of Prior Restraint, 20 LAW \& CONTEMP. PROBS. 648, 670-71 (1955). But see Martin H. Redish, The Proper Role of the Prior Restraint Doctrine in First Amendment Theory, 70 VA. L. REv. 53, 53-54, $79-86$ (1984) (noting cases where Supreme Court has been more accepting of prior restraint).

14. See New York Times v. Sullivan, 376 U.S. 254 (1964) (First Amendment applies, via the Fourteenth Amendment, to state defamation claims); see also Hustler Magazine v. Falwell, 485 U.S. 46 (1988) (First Amendment creates substantial privilege as against tort claim for intentional infliction of emotional distress).

15. See William F. Patry, The Fair Use Privilege in Copyright LaW 466 (1985) (discussing judicial use of the idea/expression dichotomy).

16. See, e.g., Robert C. Denicola, Copyright and Free Speech: Constitutional Limitations on the Protection of Expression, 67 CAL. L. REV. 283 (1979); Rochelle C. Dreyfuss, Expressive Genericity: Trademarks as Language in the Pepsi Generation, 65 NOTRE DAME L. REV. 397 (1990); Paul Goldstein, Copyright and the First Amendment, 70 CoLUM. L. REv. 983, 988-90 (1970); Pierre N. Leval, Toward $a$ Fair Use Standard, 103 HARV. L. REV. 1105, 1130-35 (1990) [hereinafter Leval, Fair Use Standard]; Pierre N. Leval, Fair Use or Foul? The Nineteenth Donald C. Brace Memorial Lecture, $36 \mathrm{~J}$. COPYRIGHT Soc'Y USA 167, 171 (1989) [hereinafter Leval, Memorial Lecture]; L. Ray Patterson, Free Speech, Copyright, and Fair Use, 40 VAND. L. REV. 1 (1987); Pamela Samuelson, Reviving Zacchini: Analyzing First Amendment Defenses in Right of Publicity and Copyright Cases, 57 TUL. L. REv. 836 (1983); Alfred C. Yen, A First Amendment Perspective on the Idea/Expression Dichotomy and Copyright in a Work's “Total Concept and Feel," 38 EMORY L.J. 393 (1989); Zimmerman, supra note 12; see also Melville B. Nimmer, Does Copyright Abridge the First Amendment Guarantees of Free Speech and Press?, 17 U.C.L.A. L. REv. 1180 (1970).

17. In First Amendment doctrine dealing with physical property, the Supreme Court shows a similar deference to owners. While at one point the Supreme Court seemed willing to recognize as a general matter that trespass laws could impermissibly erode free speech, the Court has limited that recognition to the extreme case of "company towns" whose authorities try to prohibit debate on their streets. In the shopping center cases, for example, the Court has upheld owners' rights to exclude people bearing petitions. The Court, however, has shown at least some tolerance for state efforts to keep property owners from silencing speech. See Pruneyard Shopping Ctr. v. Robins, 447 U.S. 74 (1980) (no compensation owed to owner of shopping mall who was required by state law to allow persons bearing petitions to enter his property). 
Natural-rights theory can yield significant protection for free speech interests. ${ }^{18}$ This Article argues that natural-rights principles of "desert" would, if treated as guides for practice, require courts to engage in particularized inquiries sensitive to certain speech-related interests before even reaching the constitutional question.

The Article begins by setting out the basic tenets of Lockean natural law, most fundamental among which is a duty, imposed on all, not to inflict harm on others. ${ }^{19}$ The types of claims on the part of the laborer that can give rise to property, ${ }^{20}$ and the sorts of claims that may entitle members of the public to a share in the common culture, are discussed. ${ }^{21}$ The Article then assesses how conflicts that arise between these claims should be resolved. ${ }^{22}$

The Article shows why when the public's claims conflict with a laborer's, the public's claims should prevail. ${ }^{23}$ The priority of the public's over the laborer's claims is reflected in the requirement of the Lockean proviso that "enough, and as good" must be left in common for others when a laborer wishes to appropriate a portion of the common through her labor. ${ }^{24}$ It is because it limits the reach of the concept of property that the proviso serves as a central source of significant free speech protections.

The Article then argues that the proviso can yield outcomes other than the elimination of all claims by the laborer-that there are some situations in which the laborer has a claim to reward that does not rise to the level of a property right. As a result, the primary import of the instant analysis is antiinjunctive; the Article suggests that a monetary remedy may be justifiably imposed in many instances notwithstanding the presence of free speech interests. ${ }^{25}$ Then, as a last step, before applying the natural right analysis to current controversies, the Article examines whether the Lockean theory is consistent with general patterns in the positive law, ${ }^{26}$ and with intellectual property in particular. ${ }^{27}$

The foregoing analysis is then applied to several recent controversies where intellectual property rights have largely prevailed over free speech

18. This approach would not constitute a full substitute for First Amendment protection, however. Under the natural-rights theory explored here, certain free speech concerns are part of the preconditions that must be satisfied for a creator of intangibles to deserve property rights in them. Other free expression interests of course exist, and dangers to free speech can arise in forms quite unrelated to property; such cases are outside the scope of the argument advanced here.

19. Infra Part II(A).

20. Infra Part II(B).

21. Infra Part II(C).

22. Infra Part II(D).

23. Id.

24. See John Locke, Two Treatises of Government 287-88 (Peter Laslett ed., 2d ed. 1967) (3d ed. 1698, corrected by Locke) (bk. II, § 27). The proviso is discussed in Part II(D) infra.

25. Infra Part II(E).

26. Infra Part $\mathrm{H}(\mathrm{F})(1)$.

27. Infra Part II(F)(2). 
rights. ${ }^{28}$ The Article argues that the plaintiffs in most of these cases had no justifiable property interest warranting injunctive relief, precisely because the owners sought a mode of control over how others used their creation that would impose an unjustified net harm prohibited by natural law. If so, the defendants in these cases should have been able to copy.

Finally, the Article explores the implications of a natural-rights analysis for free speech doctrine, ${ }^{29}$ as well as for policy debates steeped in consequential forms of analysis (such as economics or utilitarianism). While the Article focuses for the most part on those natural rights that protect unique, and hence noncompensable, interests, the Conclusion also takes up rights that are capable of being satisfied through trade-offs. That is, it suggests that the general population is entitled to demand that the intellectual property law make them whole when it makes incursions into those of the public's "compensable" interests that are protected by natural rights. In its entirety, the Article suggests that although natural rights give some support to what proponents of expansive intellectual property call "authors' rights," they also give support to the general population and to the population of creative users who need to employ others' work.

In sum, rather than depending on the constitutional free speech doctrine to which intellectual property courts have been too often insensitive, this Article turns instead to the very arguments that proponents of intellectual property use to defend more extensive owner control. I attempt to show how, fairly understood, these arguments lead instead to limited property rights for individual proprietors-and to significant property rights for the public. The thesis of this Article, therefore, does not rest on the First Amendment. Rather, it attempts to show that a properly conceived property theory can sometimes make recourse to the First Amendment unnecessary. One might say that the Article abandons the First Amendment ${ }^{30}$ in order to save it.

28. Infra Part III.

29. Infra Part IV.

30. Although I am working from a different tradition, my argument has parallels in First Amendment scholarship. See, e.g., C. Edwin Baker, Scope of the First Amendment Freedom of Speech, 25 U.C.L.A. 964, 966 (1978) (arguing that speech is not protected "as a means to a collective good but because of the value of speech conduct to the individual"); Sheldon H. Nahmod, Artistic Expression and Aesthetic Theory: The Beautiful, the Sublime, and the First Amendment, 1987 WIS. L. REV. 221, 226 n.19 (arguing that "artistic expression deserves full First Amendment protection"); Martin H. Redish \& Gary Lippman, Freedom of Expression and the Civic Republican Revival in Constitutional Theory: The Ominous Implications, 79 CAL. L. REV. 267 (1991) (arguing that civic republicanism reduces the value of free speech by making it a tool for the achievement of public discourse); Martin H. Redish, The Value of Free Speech, 130 U. PA. L. REV. 591, 593 (1982) (arguing that "the constitutional guarantee of free speech ultimately serves only one true value, which I have labeled 'individual self-realization"'); David A.J. Richards, Free Speech and Obscenity Law: Toward a Moral Theory of the First Amendment, 123 U. PA. L. REv. 45, 62 (1974) ("The value of free expression ... rests on its deep relation to self-respect arising from autonomous self-determination without which the life of the spirit is meager and slavish."). 


\section{A NATURAL-RIGHTS APPROACH TO INTELLECTUAL PROPERTY}

\section{A. Natural Law}

This Article takes as its organizing principle John Locke's theory of natural law, ${ }^{31}$ and, in particular, his argument that labor provides a foundation for property. ${ }^{32}$ Locke's work influenced the framers of our Constitution ${ }^{33}$ and continues to influence contemporary courts. In 1984 the Supreme Court cited Locke when it held that intangible "products of an individual's 'labour and invention"" can be "property" subject to the protection of the Takings Clause. ${ }^{34}$ Similarly, other courts have extended common law protection to intangibles on the Locke-like ground that no entity should "reap where it has not sown." 35 Locke's labor theory of property and allied approaches ${ }^{36}$ have been used so frequently as a justification for creators' ownership rights ${ }^{37}$ that Locke's Two Treatises have been erroneously credited with having developed an explicit defense of intellectual property. ${ }^{38}$ Given that versions of labor theory are so often touted as support for giving creators strong intellectual property rights, Lockean theory deserves closer examination than the intellectual property courts have given it so far. Such an examination will show that Locke's theory has much to reveal about when property in intangibles should not be granted.

31. See LOCKE, supra note 24 , at $269-78$ (bk. II, $\$ \S 4-15$ ) (describing state of nature); see also id. at 275-76 (bk. II, § 13) (comparing state of nature with civil government).

32. Id. at 285-302 (bk. II, \$§ 25-51).

33. See generally MORTON WHITE, THE PHILOSOPHY OF THE AMERICAN REVOLUTION (1978).

34. Ruckelshaus v. Monsanto Co., 467 U.S. 986, 1002-03 (1984) (citing Locke's Second Treatise, among other sources, in holding that trade-secret rights can be "property" under Fifth Amendment).

35. See, e.g., the classic case of International News Serv. v. Associated Press, 248 U.S. 215, 239 (1918); see also Board of Trade v. Dow Jones \& Co., 456 N.E.2d 84, 88-90 (Ill. 1983).

36. The motivation for many of these developments may be less Lockean labor theory per se than related notions of unjust enrichment. See Gordon, On Owning Information, supra note 10, at 167.

37. See, e.g., Harper \& Row, Publishers v. Nation Enterprises, 471 U.S. 539, 546 (1985) (suggesting that authors deserve "fair return" for labor); Ruckelshaus v. Monsanto Co., 467 U.S. 986, 1002-03 (1984) (noting that treating trade secrets as "property" is consistent with labor theories of property); Whelan Assocs. v. Jaslow Dental Lab., 797 F.2d 1222, 1235 n.27 (3d Cir. 1986) (noting copyright's longstanding concern for "just merits" as well as for public benefit); see also Robert C. Denicola, Copyright in Collections of Facts: A Theory for the Protection of Nonfiction Literary Works, 81 CoLuM L. REV. 516, 519-20, 528, 530 (1981) (suggesting that "the act of aggregating isolated pieces of information" should be grounds for copyright protection, in part because of considerations of "natural right to the fruits of one's labor" and unjust enrichment); Gordon, On Owning Information, supra note 10, at 166-67, 266-273, and sources cited therein; Gordon, Merits of Copyright, supra note 10, at 1447-48; David Ladd, The Harm of the Concept of Harm in Copyright, 30 J. COPYRIGHT SOC'Y 421, 426 (1983).

For many years courts addressing the copyrightability of compilations stretched the constitutional and statutory schemes in order to provide reward and incentives for labor. See, e.g., Nat'l Bus. Lists v. Dun \& Bradstreet, Inc., 552 F. Supp. 89, 92 (N.D. Ill. 1982). This line of precedent was discussed and repudiated by the Supreme Court in Feist Publications v. Rural Tel. Serv. Co., 111 S. Ct. 1282, 1287-89 (1991) (denying copyright in telephone book white pages on the ground that such an uncreative compilation, no matter how laboriously generated, contained no authorship).

38. See EdWARd W. Ploman \& L. Clark Hamilton, COPYRIGHT: INTELlECTUAL Property in the INFORMATION AGE 13 (1980). 
Locke tells us that in the state of nature there is no positive law parceling out ownership or giving any particular person the right to command anyone else. ${ }^{39}$ There are, however, moral duties that constrain persons' behavior toward each other. ${ }^{40}$

Locke argues that these duties are imposed by God and are discernable by reason. ${ }^{41}$ The state of nature differs from civil society primarily because the former lacks judges who can give binding interpretations of the law of nature to resolve individuals' conflicting claims. ${ }^{42}$ People form civil society precisely because its authorities ${ }^{43}$ will provide a security for natural rights which is unavailable in the state of nature. ${ }^{44}$

Since all humanity is equal in the state of nature, the duties we owe others are also the duties they owe us, and the rights I have against others they have against me. ${ }^{45}$ One can discern in Locke's theory two general classes of rights: liberty rights (areas free of duty) ${ }^{46}$ and claim rights (areas where the right-

39. The state of nature is "[a] State also of Equality, wherein all the Power and Jurisdiction is reciprocal, no one having more than another: there being nothing more evident, than that Creatures of the same species and rank promiscuously born to all the same advantages of Nature, and the use of the same faculties, should also be equal one amongst another. . . " LOCKE, supra note 24, at 269 (bk. II, § 4) (emphases omitted). "[N]o body has originally a private Dominion, exclusive of the rest of Mankind. ..." Id. at 286 (bk. II, $\$ 26$ ). See generally Locke's First Treatise, whose main point is to prove that no one person or set of persons has a claim to inherit all that was given to Adam.

40. Id. at $270-71$ (bk. II, § 6).

41. "The State of Nature has a Law of Nature to govern it, which obliges every one: And Reason, which is that Law, teaches all Mankind, who will but consult it ...." Id. at 271 (bk. II, § 6) (emphasis omitted).

I agree with John Yolton that, despite this language, the ultimate source of natural law for Locke was not reason but God. "Locke was seeking to justify a system of morality by grounding the moral law in something objective. The law of nature is a decree of God, not of man's reason. It is part of God's will." John W. Yolton, Locke on the Law of Nature, 67 PHIL. REV. 477, 483 (1958). Though the laws of nature do not originate with mankind, human reason can determine what the laws of nature are. See id. at 487-89.

42. LOCKE, supra note 24 , at $280-81$ (bk. II, § 19); Robert A. Goldwin, Locke's State of Nature in Political Society, 29 W. POL. Q. 126, 126-28 (1976).

43. The source of such judges' authority is, of course, the consent upon which Locke argues civil society is founded. See Yolton, supra note 41 , at 496.

44. LOCKE, supra note 24 , at $275-77,280-82$ (bk. II, \$\$ 13-14, 19-21). The lack of such judges is dangerous, for "where Men may be Judges in their own Case," id. at 276 (bk. II, § 13), they will likely be biased and fail to see the law clearly, leading to contention and strife. Locke thus theorizes that government begins when people seeking "the preservation of their Property ... . willingly give up every one his single power of punishing to be exercised by such alone as shall be appointed to it amongst them; and by such Rules as the Community, or those authorized by them to that purpose, shall agree on." Id. at 352 (bk. II, \$ 127). From such a process, Locke argues that society, government and laws can emerge. "II]n this we have the original right and rise of both the Legislative and Executive Power, as well as of the Governments and Societies themselves." Id. The contractarian or consensual bases of Locke's theory need not be taken literally. See Hanna Pitkin, Obligation and Consent-I, 59 AM. POL. SCt. REV. 990 (1965); Hanna Pitkin, Obligation and Consent-II, 60 AM. POL. SCI. REv. 39 (1966) [hereinafter Pitkin, Obligation \& Consent I \& II] (suggesting that the ultimate intent of consent-based political theory is to demonstrate that only governments that deserve the consent of the populace are legitimate).

45. Our equality in the state of nature means, Locke says, that "all the Power and Jurisdiction is reciprocal," LOCKE, supra note 24, at 269 (bk. II, § 4).

46. I use the phrase "liberty right" to denote the moral entitlement to do or not do something, free of duties owed to others or to God. A "liberty right" is a privilege to which one has a vested entitlement.

Translated into Hohfeld's positivist terminology, my concept of a liberty right has two components: a Hohfeldian "privilege" (a sphere of freedom from duty), backed by a Hohfeldian "right" (a sphere where one can enforce duties against others). Hohfeld used the word "privilege" to denote relations within which 
holder is owed a duty by others). ${ }^{47}$ Using these two classes, one can identify four general sets of natural rights and duties particularly relevant to our discussion. ${ }^{48}$

First and foremost, all persons have a duty not to harm others, ${ }^{49}$ except in some cases of extreme need. ${ }^{50}$ This right not to be harmed is lexically prior to the other natural rights; thus, except in cases of extreme need, the noharm duty would prevail in any conflict arising between the no-harm duty and the other natural laws mentioned below. Second, there are two key liberty rights: 1) all persons have a liberty right to dispose of their efforts as they see $\mathrm{fit}^{51}$ and 2) all persons have a liberty right to use the common ${ }^{52}$ - "the earth and all its fruits"-which God gave to humankind. ${ }^{53}$ These two liberty rights mean that, at least in the absence of extreme need, the law of nature gives no one a claim right over any other person's nonharmful use of her own efforts, or her nonharmful use of the common. Third, all persons have two central

persons had no rights and no duties in regard to each other. See Wesley Newcomb Hohfeld, Some Fundamental Legal Conceptions as Applied in Judicial Reasoning, 23 YALE L.J. 16 (1913). Hohfeld used "right" to denote an ability to call upon the government for assistance. Id. at 30-32.

The back-up "right" in a liberty right expresses the fact that the liberty is secure, and that no duties inconsistent with the liberty can be imposed. In the state of nature, the "right" component of a given liberty right reflects that fact that the prevailing system of morality-the natural law-would not permit a duty to arise that could impair the liberty. Analogously, in civil society, the "right" component of a given liberty right reflects the fact that the government has a duty not to pass laws that would impair the liberty. In our system, liberty rights are, by and large, what the Constitution's Bill of Rights gives the public.

47. A "claim right" is the correlative of a duty. The "claim right" embodies the right-holder's ability to require compliance (or compensation) from the person owing the duty. For every claim right there is a correlative duty, and vice versa. Thus, one need only know what duties exist to know what claim rights exist.

If one has a legal claim right in civil society, that means one can call upon the government to require the duty-holder to act according to her duty or to pay recompense. If one has a claim right in the state of nature, that means one can call upon the duty-holder to recognize her moral duty and one can use physical force to extract "[r]eparation" should the duty-holder in fact breach the duty. See LOCKE, supra note 24, at 272 (bk. II, $\$ 8$ ).

48. At no point does Locke spell these out so programmatically. My list is drawn from an integrated reading of the Two Treatises as a whole. I state the laws of nature in terms of liberty rights and duties, and then derive from the duties the most important of the corresponding claim rights.

49. In the Second Treatise, Locke presents the no-harm obligation as the first element of the law of nature: "[N]o one ought to harm another in his Life, Health, Liberty, or Possessions." LoCKE, supra note 24 , at 271 (bk. II, $\$ 6$ ). There is also a duty of self-preservation. Id.

50. See the discussion of charity, infra note 54 .

51. "The Labour of [one's] Body, and the Work of his Hands, we may say, are properly his." LockE, supra note 24, at 287-88 (bk. II, $\$ 27$ ) (all emphases are in the original, unless otherwise indicated). This right over one's own effort is of course subject-as are all the listed rights-to the primary duty to avoid harming others.

Locke may have meant that this liberty right over one's own effort would apply only in times of nonemergency.

52. The Article uses the word "common" rather than "commons" because the latter has connotations of a particular English institution.

53. The obligation to preserve the common extends even to that part of the common absorbed into one's property. If a laborer's possession of a bit of common stock would uselessly destroy it, the prospect of waste destroys the laborer's title to it. LOCKE, supra note 24, at 294-96 (bk. II, § 37-38); see also infra note 55 . Thus Locke notes that property can be validly held so long as the property-holder does not waste that bit of the common he has appropriated: "[H]e wasted not the common stock; destroyed no part of the portion of the Goods that belonged to others, so long as nothing perished uselessly in his hands." Id. at 299-300 (bk. II, \$ 46) (emphasis added). 
duties in regard to their resources. Each person has a duty to let others share in her resources (other than her body) in times of great need, so long as the sharer's own survival is not imperiled by such charity, ${ }^{54}$ and each has a duty to share any of her nonbodily resources which would otherwise spoil or go to waste. ${ }^{55}$ Fourth, all persons have a duty not to interfere with the resources others have appropriated or produced by laboring on the common. ${ }^{56}$ This duty is conditional, and is a keystone in the moral justification for property rights. ${ }^{57}$

Taken together, these duties and liberties generate moral claims ${ }^{58}$ and entitlements. Of these, some we possess by virtue of what we do, and some we possess by virtue of our humanity. ${ }^{59}$ Of the humanity-based entitlements, three are most important: our claim right to be free from harm, ${ }^{60}$ our claim right to have a share of others' plenty in times of our great need ${ }^{61}$ and our liberty right to use the common. ${ }^{62}$ We might call these three unearned rights "fundamental human entitlements."

54. In the First Treatise, Locke writes:

But we know God hath not left one Man so to the Mercy of another, that he may starve him if he please .... he has given his needy Brother a Right to the Surplusage of his Goods ... so Charity gives every Man a Title to so much out of another's Plenty, as will keep him from extreme want, where he has no means to subsist otherwise.

LoCKE, supra note 24, at 170 (bk. I, § 42); see also id. at 270-71 (bk. II, § 6).

55. Thus Locke writes that one can "acquire[] a Propriety" in wild fruits or beasts,

But if they perished, in his Possession, without their due use; if the Fruits rotted, or the Venison putrified, before he could spend it, he offended against the common law of Nature, and was liable to be punished; he invaded his Neighbour's share, for he had no Right, farther than his Use....

LOCKE, supra note 24, at 295 (bk. II, § 37); see also id. at 295 (bk. II, § 38) ("The same measures governed the Possession of Land too ... if . . . the Fruit of his planting perished without gathering ... this part of the Earth . . . might be the Possession of any other."). Locke's use of the word "propriety" in the material quoted here, as distinguished from his sometime use of "property" elsewhere, is insignificant. See Laslett, Introduction, in LOCKE, supra note 24, at 102-03; Karl Olivecrona, Appropriation in the State of Nature: Locke on the Origin of Property, 35 J. HIST. IDEAS 211, 218 (1974).

56. All persons have a duty not to harm others' "Possessions," see supra note 49, and labor is how one obtains possessions in the state of nature. Thus Locke writes:

Before the Appropriation of Land, he who gathered as much of the wild Fruit, killed, caught, or tamed, as many of the Beasts as he could; he that so employed his Pains about any of the spontaneous Products of Nature, as any way to alter them, from the state which Nature put them in, by placing any of his Labour on them, did thereby acquire a Propriety in them.

LOCKE, supra note 24 , at 294-95 (bk. II, § 37).

For land, too, "Whatsoever he tilled and reaped, laid up and made use of, before it spoiled, that was his peculiar Right." Id. at 295-96 (bk. II, § 38).

57. See supra note 56, and discussion at Part II(B)(1), infra.

58. I use the term "claim" or "moral claim" to indicate anything that puts weight on the moral scale. Therefore a "claim" includes conditional as well as fully effective entitlements. A "claim" is not the same as a "claim right." A "claim right" is always the correlative of a duty, and is a mature and fully effective entitlement.

59. Cf. Jeremy WALdRon, The RIGHT to Private Property 109-24 (1988) (distinguishing "special rights" and "general rights").

60. See supra note 49 and accompanying text.

61. See supra note 54 and accompanying text; see also infra note 130 and accompanying text.

62. See supra note 52 and accompanying text.

63. See Allen Buchanan, Justice as Reciprocity Versus Subject-Centered Justice, 19 PHIL. \& PUB. AFF. $227,244-45$ (1990) (suggesting that persons unable to contribute to the social surplus may nevertheless 
As individuals we can take actions that cause us to deserve more or less than these fundamental human entitlements would dictate. Most notably, if we work productively, our labor may entitle us to own more goods than less industrious people are entitled to have.$^{64}$ But by our own actions we cannot give ourselves a right to impair others' fundamental human entitlements. We cannot "earn" a right to harm others, ${ }^{65}$ or a right to impair their access to the common. ${ }^{66}$

This Article seeks to answer a basic question at the heart of Lockean natural law: what happens when a conflict arises between fundamental entitlements of the public, and the moral claims that a creative laborer possesses by virtue of having created an intellectual product? The next two Sections, B and C, will describe respectively the laborer's claims and the public's entitlements. Section D will present the correct method for resolving conflicts between the two types of claims.

\section{B. The Laborer's Claims}

The law of nature summarized earlier suggested that property could arise in the state of nature when someone labors on the common, either by appropriating from it directly-drawing water from a stream, picking apples from a wild tree- or by making something from it. This Section suggests that the ethical structure of Locke's argument has persuasive power even for a secular ethicist who does not share Locke's theological premises. The Section then defines the various entitlements that constitute conventional property and investigates the extent to which the creator of intangible products in the Lockean system might have a natural-rights claim to possess these entitlements in regard to her creations.

\section{The Harm-based Structure of Locke's Argument for Property}

Locke's property theory has many strands, some of which are overtly utilitarian and others of which draw on varying notions of desert. ${ }^{67}$ To the extent that his theory purports to state a nonconsequentialist natural right in property, it is most firmly based on the most fundamental law of nature, the "no-harm principle." The essential logic is simple: Labor is mine and when I

have "basic rights to resources," $i d$. at 231).

64. See supra note 56 and accompanying text.

65. A person loses his claim right against harm only by his own action. Thus Locke notes that if someone breaks the law of nature, everyone is entitled to punish the transgressor to a degree suitable to "serve for Reparation and Restraint. For these two are the only reasons, why one Man may lawfully do harm to another. ..." LoCKE, supra note 24, at 271-72 (bk. II, § 8) (emphasis added).

66. This may be derived from the general no-harm condition, $i d$. at $270-71$ (bk. II, $\S 6$ ), and from the general structure of Locke's argument in the Second Treatise, as discussed infra in Part II(C)(1).

67. See, e.g., LAWRence BeCKer, Property Rights: Philosophic Foundations 32-48 (1977). 
appropriate objects from the common I join my labor to them. If you take the objects I have gathered you have also taken my labor, since I have attached my labor to the objects in question. This harms me, and you should not harm me. You therefore have a duty to leave these objects alone. Therefore I have property in the objects. ${ }^{68}$

Similarly, if I use the public domain to create a new intangible work of authorship or invention, you should not harm me by copying it and interfering with my plans for it. I therefore have property in the intangible as well.

To analyze whether this conception can serve as a tenable guide for modern decisions about the ethics of property, three issues must be addressed. First, a strict no-harm rule merely enshrines a status quo, so that Locke's natural right against harm is unpersuasively overbroad. What needs to be established is not simply whether harm is done, but rather whether there is an unjustified or wrongful harm. Second, labor is not itself property. Therefore, even if persons are entitled to be free of some kinds of harm, it remains to be shown that the same right pertains to their labor. Third, it is possible that a harm-based argument for property cannot validate intellectual property, for the "public goods" characteristics of intangible creations make them infinitely capable of being shared without depriving the initial creator of their use. ${ }^{69} \mathrm{I}$ will address each of these in turn.

As to wrongful harm, Locke argued that the only justifiable harm was punishment properly meted out to someone who violated the law of nature. ${ }^{70}$ Even if there are a host of potentially justifiable intentional harms-in other words, even if Locke were wrong-his argument for property would not be undermined, since it rests on a particular kind of harm that virtually all would agree is wrongful. The stranger whom Locke rebukes for taking a laborer's property is one who "desired the benefit of another's Pains, which he had no right to." 71

Imagine that there is a forest of wild apple trees in full fruit, and that someone has collected a few apples from each tree and piled the apples neatly

68. See generally LOCKE, supra note $24,285-302$ (bk. II, $\S \S 25-51$ ). Karl Olivecrona's interpretation of Locke thus comes closest to the interpretation I am offering. Olivecrona argues that Locke perceived the fruits of labor to be an extension of the laborer's personality and, since it was therefore part of the laborer's sphere of personality or "suum," it should be protected from harm. See Olivecrona, supra note 55, at 21920, 221-26. For Locke, "when the object [appropriated] has been included within [the] sphere [of the personality], it will be an injury to the possessor to deprive him of it." Id. at 211, 223; see also Karl Olivecrona, The Term "Property" in Locke's Two Treatises of Government, 61 ARCHIV FUR RECHTS-UND SOZIALPHILOSOPHIE 109, 112-14 (1975) [hereinafter Olivecrona, Term "Property"] (discussion of "suum" in natural rights theory). Olivecrona, however, does not try to justify the Lockean approach in deontologic terms; further, I disagree with Olivecrona's perception that Locke evaded the key issue in justifying property rights, namely, that property imposes duties. See Olivecrona, supra note 55, at 223 (discussion of ownership or dominium as a facultas moralis), examined infra at note 106 and accompanying text.

69. On the "public goods" nature of intellectual products, see Gordon, Fair Use, supra note 11, at $1610-14$, and sources cited therein.

70. See supra note 65 and accompanying text.

71. LoCKE, supra note 24, at 291 (bk. II, § 34). 
on some moss with the expectation of taking them home to eat. Imagine further that the gatherer has left more than enough fruit on easily-reached boughs to satisfy anyone who might come along, that she has posted a notice on the apples declaring the nature of her investment and interest in them, and that the apples in her pile are no better than any of the apples remaining on the trees. If a stranger came along-someone whose characteristics are no different from what the laborer's were when she began work that morning-and he took her apples, it would be clear he was taking them only to save his labor. After all, in the absence of a desire to save labor, he would have picked apples of his own.

The apple-taking stranger can offer no justification for his act except that he prefers his own welfare over the gatherer's. This will not justify his action, since he commits a fundamental wrong when he uses another solely as a means toward his own welfare. The stranger is treating the laborer not only "as if [s] he existed for purposes [s] doe does not share," ${ }^{, 2}$ but also as if she were less worthy than he. Thus, even a narrowly drawn prohibition on unjustified harm would condemn the stranger's actions and so create against such strangers a property right in the gatherer. Similarly, someone who creates an intangible has moral rights against noncreative copyists who copy purely from commercial motivation if, like the stranger who takes the apples, their sole aim is to substitute another's efforts for their own.

But none of this tells us why the laborer has a right to the fruits of her labors, be they apples or intangibles, in the first place. It may be clear that others have a prima facie duty not to take what is yours for their own benefit, but it is still necessary to decide what is yours and what is theirs. That brings us to the discussion of the second issue, namely that labor is not property.

Property has at least two meanings in the law. We can say that "property" is any vested entitlement, or alternatively "property" can mean that particular complex of entitlements-such as the right to exclude and the power of transfer-usually associated with ownership. It is a mistake to think that only property in the latter sense is protected against harm. The positive law protects a wide variety of nonowned interests from malicious harm, even to the extent of invalidating a malicious property owner's ordinary entitlements. ${ }^{73}$ The interests that courts have protected range widely beyond property: examples

72. Warren S. Quinn, Actions, Intention, and Consequences: The Doctrine of Double Effect, in ETHICs: PROBlEMS AND PRINCIPLES 178, 190 n.25 (John Martin Fisher \& Mark Ravizza, eds., 1991) (examining a Kantian perspective on the controversial "doctrine of double effect"). Even for an economist the stranger's behavior is unjustified: the stranger has done nothing productive, $c f$. ROBERT NOZICK, ANARCHY, STATE AND UTOPIA 84-86 (1974) (discussing notion of "unproductive exchange"), and may cause disincentives to the gatherer. The stranger's taking may also trigger future transaction costs (fence-building and the like) that serve no allocative end. See, e.g., Ronald Coase, Blackmail: The 1987 McCorkle Lecture, 74 VA. L. REV. 655 (1988) (nonallocative blackmail transactions impose wasteful transaction costs).

73. For example, a homeowner's interest in a clear view is not something the law ordinarily recognizes or protects. But if a homeowner's neighbor erects a "spite fence," a court may take action against it. 
range from mental tranquility ${ }^{74}$ to prospective advantages ${ }^{75}$ such as wild ducks not yet caught ${ }^{76}$ or barbers' customers. ${ }^{77}$ One need not approve these particular cases or doctrines to recognize that an interest is not disqualified from all protection simply because it is not ownable in the usual sense. These cases and doctrines seek to protect something from harm in which the claimant has an interest or stake. ${ }^{78}$ Does Lockean labor invested in a tangible or intangible item constitute such a stake?

Locke himself offered no precise definition of the kind of appropriative labor that could give rise to a property claim, ${ }^{79}$ and his notion of labor has been much debated. The ambiguities of his text are multiplied when one tries to extrapolate from its physical examples, such as picking up acorns, drawing water from the river, or putting land under cultivation, to the intangible realm. Some things, however, are fairly clear. Aimless effort is not labor. Appropriative labor involves altering what was in the common in a way that makes it usable and thus more valuable to humanity. ${ }^{80}$ It may also involve a kind of psychological identification, an "infusion of personality." important from the perspective of the laborer's claim, however, is the laborer's purposiveness. ${ }^{82} \mathrm{~A}$ stranger's taking of another's labored-on objects is likely to merit legal intervention only if the taking interferes with a goal or project to which the laborer has purposely directed her effort. ${ }^{83}$ If the taking does

74. See, e.g., RESTATEMENT (SECOND) OF TORTS $§ 46$ (1965) (intentional or reckless infliction of emotional distress).

75. On the general tort known as "interference with prospective advantage," see W. PAGE KEETON ET al., PROSSER AND KEATON ON TORTS $\$ 130,1005-30$ (5th ed. 1984).

76. Keeble v. Hickeringill, 90 Eng. Rep. 1127 (K.B. 1809) (nonproperty interest in wild ducks attracted by decoy sufficient to give plaintiff right of action against defendant who intentionally scared ducks away).

77. Tuttle v. Buck, 119 N.W. 946 (Minn. 1909) (barber had cause of action when another barber was allegedly set up in a competing shop solely to harm plaintiff's business).

78. See 1 Joel Feinberg, Moral Limits of the CRiminal Law: HARM to Others, 33-34 (1984) (harm as setback to interests). "The test ... of whether ... an invasion has in fact set back an interest is whether that interest is in a worse condition than it would otherwise have been in had the invasion not occurred at all." Id. at 34 .

79. See Olivecrona, supra note 55 , at 225 .

80. See LOCKE, supra note 24, at 286-91 (bk. II, $\$ \S 26-33$ ); see also BECKER, supra note 67, at 50; cf. NozicK supra note 72 , at 175.

81. Olivecrona sees this as a common theme in seventeenth-century natural law writing. See Olivecrona, supra note 55, at 215-16 (discussing Pufendorf), 224 (discussing Locke); see also BECKER, supra note 67 , at $48-49$.

82. Locke's examples generally involve deliberate appropriation for the purpose of use or enjoyment. For example, Locke wrote: "As much Land as a Man Tills, Plants, Improves, Cultivates and can use the Product of, so much is his Property. He by his Labour does, as it were, inclose it from the Common." LOCKE, supra note 24, 290-91 (bk. II, \$32) (emphases omitted); see also BECKER, supra note 67, at 33-34 (accidental additions of value do not count); JAMES TULLY, A DisCOURSE ON PROPERTY: JOHN LOCKE AND HIS ADVERSARIES 121-24 (1980).

83. See generally the discussion of unjustified harm in Wendy J. Gordon, Truth and Consequences: The Force of Blackmail's Central Case, 141 U. PENN. L. REv. (forthcoming May 1993); Gordon, On Owning Information, supra note 10, at 190-93, 238-48 (defining scope of protectable interests under corrective justice principles). 
interfere, the actor needs some special justification for doing it. ${ }^{84}$ The scope of the laborer's purpose will help to define the scope of the rights she can assert. ${ }^{85}$

Turning to the third issue, the idea that copying intellectual products cannot be harmful because intellectual products are physically inexhaustible "public goods," it would appear to lack merit. Copying can harm important interests even if the copying does not deprive the creator of physical use of her creation. For example, if someone creates music not only for the sake of listening to it herself, but also for the purpose of feeding herself by selling the royalties to it, she can be harmed by a bootleg copyist as severely as if he took the physical sheet music out of her den or stole the food she had bought. The intellectual laborer requires some kind of anti-copying protection if her property in her creations is to be meaningful.

There are, however, some differences between tangible and intangible property that may be relevant from a normative standpoint. When a stranger takes the apples another has labored to pick, he steps into the laborer's shoes; by the terms of the hypothesized situation, the laborer and the stranger are the same except insofar as one has labored and one has not, so the stranger is no better situated than the laborer was to eat, sell, or make pies from the fruit. From an economic perspective, therefore, the transfer of apples to the stranger's possession has no predictable allocative significance except insofar as it may alter laborers' future incentives in negative ways-discouraging labor and encouraging laborers to make wasteful expenditures on defensive measures to protect their harvests. By contrast, if a stranger copies an intangible product, he is not stepping into the laborer's shoes. Since the copyist does not divest the laborer of possession, the copying adds another source of the intellectual product to the world. If the copyist distributes many copies to the public, it will decrease the "deadweight loss" ${ }^{\text {"6 }}$ to which an author's right against

84. Commentators generally agree that purpose is relevant to any conception of Lockean labor or “appropriation." See, e.g., Becker, PROPERTY RIGHTS, supra note 67, at 52-53.

85. See Gordon, On Owning Information, supra note 10, at 188-96, 238-48, and sources cited therein. The common law's patterns of liability and reward in tort and restitution similarly limit claims to what could have been foreseen. Id. at 188-96, 204-05. Cf., DAVID GAUTHIER, MORALS BY AGREEMENT 293 (1988) ("[T]he rights acquired in an act of appropriation are determined by the context of the act and the uses made of what is appropriated ....").

86. As a result of intellectual property rights, the price charged can be greater than the marginal cost of copying. For example, when a competitor copies a computer program written by someone else, the marginal cost per copy will likely be low: the costs of a new floppy disk and of using a computer or other copy device for a few minutes. Yet the person who invested a great deal in initially creating that intangible will need to charge more than the marginal cost of copying in order to recoup her investment. Copyright excludes the competitor from putting identical floppies on the market, making it possible for the owner of the program's copyright to charge a price that more than covers marginal cost, but at the expense of the deadweight loss. "Deadweight loss" represents the economic costs of granting anti-copying rights in existing works:

[C]onsumers who value the work at more than its marginal cost but less than its monopoly price will not buy it. ... [This] results in a "deadweight loss," measured by the total of the consumer surplus that would have been reaped by the excluded consumers and the producer surplus that would have been reaped by the copyright owner had he sold the work to them. 
copying almost always gives rise. Unlike physical takings, then, copying produces a positive short-term allocative effect which could outweigh its longterm negative incentive effects on future creators. ${ }^{87}$ Does this difference in potential economic effect justify the harm caused by the copyist stranger in a way that the harm caused by apple-taking stranger cannot be justified? From a Lockean perspective, it does not.

For the public's needs to justify harming the laborer they must have some particular moral weight, such as claims based on exigency ("charity"), or the public's own right to have unharmed access to the common. Nothing in a natural-rights framework gives the public the per se entitlement to cheap access. to what the laborer has produced. As I have argued elsewhere, the public has no prima facie right to the price and quantity of intellectual products that would be available in a world devoid of intellectual property law. ${ }^{88}$ The public has no more right to the "benefit of another's pains"89 than the appletaking stranger had.

"Deadweight loss" merely measures the difference between what society gains from an intellectual product distributed subject to anticopying restraints, and what society would gain from a freely-copied intellectual product. Avoiding "deadweight loss" is a natural right only if the public has a right to free copying. As just discussed, it has no such right. Granting laborers anticopying rights that may make some works more expensive or less accessible thus does not deny the public anything to which it is entitled, with the result that the unconsented copyist who harms the laborer is not justified by the benefit his act may give the public. The claims of the laborer who produces intangibles and the claims of the laborer who works with physical objects are therefore of equal strength.

\section{The Nature of Lockean Property Entitlements}

For years, scholars have disputed what Locke had in mind when he used the word "property." all of one's entitlements, including "Lives, Liberties, and Estates." Subsection restricts its attention to the circumstances under which Locke's

William W. Fisher, III, Reconstructing the Fair Use Doctrine, 101 HARV L. REV. 1659, 1702 (1988).

87. It has of course been much debated whether or not (in particular industries or on the whole) the reduction in deadweight loss is likely to be greater than the loss resulting from the impairment of incentives. See, e.g., Stephen Breyer, The Uneasy Case for Copyright: A Study of Copyright in Books, Photocopies, and Computer Programs, 84 HARv. L. REv. 281, 350 (1970) (arguing that, for at least certain classes of works, a strong economic case for copyright protection cannot be made).

88. See Gordon, Merits of Copyright, supra note 10 at 1435-65.

89. Locke, supra note 24 , at 291 (bk. II, $\$ 34$ ); see also supra note 51 and accompanying text.

90. See generally, TULLY, supra note 82, at 131; Laslett, Introduction, in LOCKE, supra note 24 , at 102-03 (sources cited therein).

91. LOCKE, supra note 24 , at 350 (bk. II, § 123). 
moral law envisaged conventional property rights in tangible things and intellectual products.

Conventional property in the Anglo-American system usually includes at least three entitlements. First, a property owner has a liberty to consume the property and use it harmlessly. Second, an owner has a power to transfer the property. ${ }^{92}$ Third, an owner has a claim right to exclude anyone whose entrance or interfering use she wishes to oppose. ${ }^{93}$ The discussion below explores these three crucial entitlements in Locke. ${ }^{94}$

\section{a. Liberty Right to Use One's Property}

Locke argues in favor of appropriation, consumption, and use. ${ }^{95}$ The owner possesses a broad privilege or liberty to use her property in any way she sees fit, as long as it causes others no harm. ${ }^{96}$ Locke's argument concerning the necessity of property rights rests heavily upon the liberty rights to appropriate, consume, and use harmlessly. He writes:

[The earth's fruits and beasts] being given for the use of Men, there must of necessity be a means to appropriate them some way or other before they can be of any use, or at all beneficial to any particular Man. The Fruit, or Venison, which nourishes the wild Indian . . . must be his, and so his, i.e. a part of him, that another can no longer have any right to it, before it can do him any good for the support of his Life. ${ }^{97}$

If others have no right to the nourishment someone has gathered, the gatherer violates no duty in eating it. She has a rightful liberty to consume.

As noted above, however, the natural law imposes restraints on one's liberties to use one's property, such as the duty to refrain from harm. ${ }^{98}$

92. I use the word "power" as Hohfeld did, namely to indicate a person's ability to change his own and others' legal relations. WESLEY N. HOHFELD, FUNDAMENTAL LEGAL CONCEPTIONS 50-64 (Walter W. Cook, ed., 1923).

93. See Ruckelshaus v. Monsanto Co., 467 U.S. 986, 1003 (1984) (forced sharing of trade secrets held to constitute a "taking" of "property"; Takings Clause applicable not to things per se but to "right to possess, use and dispose" of them).

94. There is some support in the literature for the claim that Locke had "conventional" property in mind. Chemo, for example, suggests that in the chapter on property, "we may take Locke to mean 'property' as we ordinarily use the term." Melvin Chemo, Locke on Property: A Reappraisal, 68 ETHICS 51 (1957); cf. Laslett, Introduction, in LOCKE, supra note 24, at 102 ("[I]n the chapter on property . . . it is clear that material possessions are meant.").

95. LOCKE, supra note 24 , at $286-88$ (bk. II, §§ 26-27).

96. The American system also contains a presumptive privilege for harmless use. See Gordon, Merits of Copyright, supra note 10, at 1362-65. The reader might challenge the privilege of consumption on the ground that one person's using up a bit of the common thereby deprives others of its use. As will be discussed later, however, property in the state of nature does not arise if the appropriator leaves others less able to use the common than they otherwise would be. See infra Parts II(D)-(E).

97. LOCKE, supra note 24 , at 286-87 (bk. II, \$\$ 26-27).

98. See supra note 49 and accompanying text. 
Moreover, even if a laborer is ordinarily at liberty to keep the benefits she can draw from her product, the natural law imposes on her an obligation to share her plenty with those in extreme need. ${ }^{99}$ As a result of this duty, in combination with the "waste" limitation that requires that one not allow one's property to perish uselessly, ${ }^{100}$ the laborer's freedom not to use the product may be limited.

Most of these liberties (and their limitations) are applicable to the realm of intangibles. The "waste" limitation, for example, might restrict a misanthropic inventor of a cure for cancer from destroying her notes. Similarly, a liberty of harmless use does not pose particular analytic complexities regarding intangibles, and appears applicable to intellectual products. Someone who creates an intangible should be at liberty to use it.

\section{b. Power of Transfer}

Locke assumes contracts can be made in the state of nature. ${ }^{101} \mathrm{He}$ clearly envisages the barter or sale of objects. ${ }^{102}$ Some things, however, namely those that are inalienable under the law of nature, cannot be sold. ${ }^{103}$ Because persons are stewards of their lives, responsible to God, ${ }^{104}$ they cannot choose to enslave their bodies. ${ }^{105}$ Mental liberties essential to the rational life of a servant of God would also presumably not be alienable. People thus may not sell those things that are essential to their lives, but they may otherwise sell or trade what they appropriate or make from the common.

Because of the intangible nature of intellectual products, it may be impossible for the creator of an intellectual product to divest herself of it fully. For example, a composer is unlikely to forget her music when she sells the copyright to it. The entitlements in intellectual products can nevertheless be transferred: the creator can impose on herself by contract a duty to cease using what she has made, and transfer all her rights and powers over the use of the intangible to someone else. Therefore intellectual products, like other products of labor, are capable of being subject to a power of transfer.

99. See supra note 54 and accompanying text.

100. See supra note 53 and accompanying text.

101. See, e.g., LoCKE, supra note 24, at 276-77 (bk. II, § 14); id. at 330-31 (bk. II, § 95) (persons can form governments by the power of consent).

102. LOCKE, supra note 24, at 294-95, 299-301 (bk. II, $\S \S 37,46-48$ ) (assuming the trading or buying of property). Whether under natural law the power of transfer would have to be conditioned by limits similar to those pertaining to the original acquisition of property this Article does not address.

103. See Yolton, supra note 41 , at 494 . Note that Morton White makes a distinction between not being a proprietor of what one possesses, and being unable to alienate what one owns. See WHITE, supra note 33, at 210-11 (" $[\mathrm{A}]$ man does not have the 'power of his own life' and therefore does not have it to alienate ...."; by contrast, a man does have "the power to preserve his life .... This second right Locke would have called 'unalienable' had he used that term in this context ....").

104. See Locke, supra note 24 , at $270-71$ (bk.II, $\S 6$ ).

105. LOCKE, supra note 24, at 284 (bk. II, § 23): "[A] Man . . cannot, by Compact, or his own Consent, enslave himself to any one, nor put himself under the Absolute, Arbitrary Power of another." 


\section{c. The Claim Right to Exclude}

A property owner ordinarily has a claim right to have others refrain from entering or otherwise interfering with the property. She also has a power to waive the right and give others permission to make use of the property. The claim right to exclude is usually "good against the world," which means that all persons in the world have a correlative, prima facie duty to respect it. In positive law, it is when someone breaches this correlative duty that the right to exclude is most obvious, for then the owner brings a trespass suit (for land) or an infringement suit (for an intellectual product) to enforce the right. The correlation between rights and duties forms a part of natural law theory as well. If one held a moral right or ius over another, that other was "in a state of subjection" to the right-holder. The "moral power" of the right-holder was termed a facultas moralis, and this power to prohibit others from using our possessions is " $[t]$ he force of the right of property."

It is often argued that the "essence" of property is "the right to exclude others." 107 The claim right to exclude protects the owner's ability to say "no" until the other party pays consideration the owner thinks suitable. This right, then, is the condition for the existence of self-executing markets. For intangibles, the parallel entitlement to the right to exclude physically is the right to forbid others' use of one's product. ${ }^{108}$ This species of entitlement is as vital in the intellectual property context as it is in the context of tangibles.

Since Locke argues that people form governments precisely to make their property more secure, ${ }^{109}$ and since the claim right to exclude is such a valuable part of property, one would expect this right to play a role in the state of nature. ${ }^{110}$ And Locke does indicate that one who harms another in his "Life, Health, Liberty or Possessions"111 has violated a duty under the law

106. Olivecrona, supra note 55 , at 214 . Olivecrona writes:

Dominium, as every other right, was a facultas moralis. It was a moral power in the owner over the minds of all other men to request them to abstain from the object and restore it if they had gained possession of it without the consent of the owner. Id. at 222 .

107. Morris Cohen, Property and Sovereignty, 13 CORNELL L.Q. 8, 12 (1928). Whether such rights to exclude are indeed more important than other property entitlements does not matter. Caselaw and commentators agree that the right to exclude is an essential element in what we know as "property." See, e.g., Nollan v. California Coastal Comm'n, 107 S. Ct. 3141, 3145 (1987).

108. See Gordon, Merits of Copyright, supra note 10, at 1365-73 (exclusive rights in copyright). An important issue is, of course, how broadly to define the scope of a laborer's rights over the "use" of a creation. See, e.g., infra text accompanying note 238 (concerning rights over independent recreation). For a fuller discussion, see Wendy J. Gordon, The Shape of Intellectual Property Rights Under Natural Law (unpublished manuscript; on file with the author) [hereinafter Gordon, Shape of Intellectual Property Rights].

109. LOCKE, supra note 24 , at $350-51$ (bk. II, § 124).

110. Even when not backed by positive law, there can be a claim right to exclude: a moral right that others have a moral duty to respect. See supra note 47.

111. LOCKE, supra note 24 , at $271,280-81$ (bk. II, $\S 6$ ). 
of nature. ${ }^{112}$ This indicates that the owners of possessions have at least a claim right good against the most important intrusions, namely, those that are harmful.

To be sure, Locke's treatment of the right to exclude is somewhat unclear. $\mathrm{He}$ was more concerned with arguing that individuals in the state of nature would have had a rightful liberty to use the earth's plenty ${ }^{113}$ than with the idea that productive individuals have claim rights over others. The obscurity of his treatment of the latter issue is such that even a thoughtful commentator such as Karl Olivecrona seems to think that Locke ignored the concept of a claim right over property-worse, that the concept "is never mentioned or presupposed" in either of the Two Treatises. ${ }^{114}$

To suggest that Locke was merely concerned with justifying liberty rights of consumption, however, is too restrictive of his intent. The defining characteristic of liberty rights is an absence of restraint, whether legal (in civil society) or moral (in the state of nature). ${ }^{115}$ Therefore struggles between the holders of liberty rights are indeterminate as far as moral or legal result is concerned. ${ }^{116}$ Notwithstanding Locke's sometimes bucolic image of the state of nature- $a$ land of abundant space where each holder of liberty rights could work her plot of earth without need to struggle with her neighbor-Locke was concerned with the possibility of conflict. ${ }^{177} \mathrm{He}$ could hardly have thought the competitive realm of liberty rights capable of generating the security he imagined the enforcement of natural law would bring. ${ }^{118}$

We will return later to the question of the scope of an owner's claim right to exclude. For now, it is enough to note that the laborer who achieves property in what she takes from or makes from the common, has a claim right in it that all others have a prima facie duty to respect.

112. See LOCKE, supra note 24 , at 272 (bk. II, $\S \S 8,19$ ) (thieves may be punished).

113. See infra note 172 (Locke wanted to show that mankind could make beneficial use of the earth while conforming to natural law and without the need for monarchs.).

114. See Olivecrona, supra note 55, at 223. It was the crucial concept of facultus moralis - of claimright-that Olivecrona claims Locke ignored, despite its importance to previous writers whose works Locke had utilized. $I d$. at $211,214,222-23$. Olivecrona argues that by ignoring the duties that property imposes on other men, Locke's task was made "easier." Id. at 223.

115. Persons holding liberty rights have no natural law superiority one over the other. Where liberty prevails, there are no rights and duties. See supra notes $46-47$ (defining claim rights and liberty rights.)

116. A sphere of liberty or privilege merely excludes others' claim-rights-it does not exclude others from exercising their own liberties. For example, should two people each become entitled to a "privilege of self-defense" against the other (perhaps because they both are laboring under reasonable mistake as to the threat posed by the other), each is free to attack the other. As privilege-holders they are free from the imposition of duty, but the privilege does not give any special immunity from risk or harm. See generally Joseph William Singer, The Legal Rights Debate in Analytical Jurisprudence from Bentham to Hohfeld, 1982 WIS. L. REv. 975 (discussing Hohfeld's influence in helping the legal profession understand the inevitable costs of entitlements).

117. LOCKE, supra note 24 , at $275-76,281-82$ (bk. II, $\S \S 13,20-21$ ).

118. LOCKE, supra note 24, at 281-82 (bk. II, $\$ \S 20-21$ ) ("[I]n the State of Nature, for want of positive Laws, and Judges with Authority to appeal to, the State of War once begun, continues. . .") (emphasis omitted). 


\section{From Natural Property Rights to Property in Civil Society}

Are natural property rights enforceable in civil society? It appears so.

Locke argues that people enter civil society in order to obtain security in the enjoyment of their natural rights. ${ }^{119}$ In the state of nature, everyone was at liberty to punish violations of the law of nature themselves, ${ }^{120}$ and this led to discord. ${ }^{121}$ When people enter civil society, however, they bind themselves to refrain from exercising this liberty, ${ }^{122}$ and delegate it to the commonwealth. ${ }^{123}$ Once the commonwealth has the liberty (and perhaps the duty) ${ }^{124}$ to punish violations of the law of nature, natural claim rights come closer to something a positivist would recognize as legal rights: violation of them induces governmental action.

Locke's argument suggests that government exists only to enforce natural law, and that it is constrained by its precepts. ${ }^{125}$ Other than the relinquished

119. Thus Locke writes:

If Man in the State of Nature ... be absolute Lord of his own Person and Possessions, equal to the greatest, and subject to no Body, why will he part with his Freedom? Why will he give up this Empire ... ? To which 'tis obvious to Answer, that though in the state of Nature he hath such a right, yet the Enjoyment of it is very uncertain. .."

Locke, supra note 24, at 350 (bk. II, § 123).

120. Id., at 270-73 (bk. II, §§ 6-9); see also id., at 357-58 (bk. II, § 135); id., at 353 (bk. II, § 130). Prior to civil society, the community has the privilege of pursuing and punishing the offender, and returning the property to its owner, id., at 270-73 (bk. II, §§ 6-9), but has no duty to do so. Id. (by implication). This unwillingness to give victims a right to community assistance against wrongdoers is not surprising, given the primacy Locke places on liberty. He would be reluctant to impose a moral obligation on community members to bend their wills to someone else's purposes, even when the purpose is redressing and punishing an offense against the law of nature. And if the community has no duty, then the owner has no "right" in the familiar legal sense.

121. Id., at 350-52 (bk. II, \$§ 123-27).

122. Id. at $352-53$ (bk. II, $\$ \$ 127-31$ ).

123. Id. at 352-53 (bk. II, $\S \S 127,130-31$ ); see also supra note 44 .

Locke does not discuss how the costs of enforcement are to be borne. For the sake of simplicity, the Article will assume that the governmental costs of enforcing property rights should be bome by the person seeking the enforcement-or otherwise in a manner that will give a covetous and contentious stranger no ground for complaint. To the extent that this assumption does not match reality, of course, the system of rights so generated would be vulnerable to criticism based on the argument that persons in a Lockean system have a right not to be "harmed" absent exigent need.

124. Presumably when persons enter civil society and delegate their liberty of action to the government (so that the government can imprison and otherwise harm offenders), they condition that delegation on the government's accepting a duty to enforce natural law. Otherwise, there would be little sense in the bargain made. (This is not to say that American courts accept the notion that individuals can sue the government for failures of enforcement.)

125. Locke writes,

The Obligations of the Law of Nature, cease not in Society, but only in many Cases are drawn closer, and have by Humane Laws known Penalties annexed to them, to enforce their observation. . . . The Rules [Legislators] make for other Mens Actions, must . . . be conformable to the Law of Nature. ...

LOCKE, supra note 24 at 357-58 (bk. II, $\S 135$ ) (original spelling preserved).

Locke's position on this issue is, typically, less than crystal clear. Thus James Tully argues that Locke believed all rights would be conventional after the formation of civil society, taking their form from the will of the consensually-formed government unconstrained by the law of nature. See TULLY, supra note 82 , at $84,164-65$. There is some evidence for Tully's view. Thus Locke notes that the legislature may "dispose[] of" the "Equality, Liberty, and Executive Power [men] had in the State of Nature" "as the good of the Society shall require." LOCKE, supra note 24 at 353 (bk. II, § 131). Yet in this latter passage Locke 
liberty right of pursuing and punishing offenders, the individual retains virtually all the other rights and duties of the law of nature in civil society. In civil society they become legal rights and duties. After all, if the purpose of government is "the preservation of their Property,"126 part of which is the "estate" one possesses, ${ }^{127}$ it is logical to expect one's natural property rights to be guaranteed by law in civil society. Thus, even though we are no longer in a state of nature, Lockean theory remains available as an appropriate source of guidance for positive law.

\section{The Public's Entitlements}

The public has entitlements in order to ensure equality between persons and to give human beings what they need to flourish. ${ }^{128}$ Let us begin with the latter. In order to flourish, all people need a degree of security. Lockean natural law therefore seeks to provide people with a right against harm. ${ }^{129}$ People also need minimal sustenance. Thus, Lockean natural law gives all persons, whether or not in distress, a liberty to take from the earth a portion of that which all own in common. ${ }^{130}$ Yet the need for sustenance is not simply physical: it comprises our intellectual, expressive, and artistic needs as well. ${ }^{131}$ People must have access not only to the physical common of which Locke explicitly writes, but also to a common of intangibles. Our common encompasses not only our physical country but our culture as well. ${ }^{132}$

may have had in mind regulation that "will not involve the wholesale abrogation of natural property rights, but rather merely their subjection to the conditions necessary for their effective and positive protection." Jeremy Waldron, Locke, Tully, and the Regulation of Property, 32 POL. STUD. 98, at 105 (1984) (construing other sections in the Second Treatise). This seems likely, for in the very same section Locke goes on to note that

though Men when they enter into an Society, give up the Equality, Liberty, and Executive Power they had in the State of Nature ... yet it being only with an intention in every one the better to preserve himself his Liberty and Property; (For no rational Creature can be supposed to change his condition with an intention to be worse) ...

LOCKE, supra note 24, at 353 (bk. II, $\S 131$ ). I agree with Jeremy Waldron and others that, for Locke, government existed to enforce the laws of nature and could not exceed or abridge them. See Waldron, supra, at 103-04.

126. LOCKE, supra note 24 , at 350-52 (bk. II, $\$ 1124,127$ ) (emphasis omitted).

127. Persons create civil commonwealths to preserve "their Lives, Liberties and Estates, which [Locke] call[s] by the general Name, Property." Id. at 350 (bk. II, $\$ 123$ ).

128. Cf. Margaret Jane Radin, Market-Inalienability, 100 HARV. L. REv. 1849, 1903-07 (1987) (discussing relationship between property and human flourishing).

129. Of course the kinds of harms protected against claim rights need to be specified to avoid indeterminacy. On indeterminacy in property orderings, see Gordon, Merits of Copyright, supra note 10, at $1422-25$.

130. Lockean natural law also gives all persons in distress a right to minimal sustenance as against persons who have a surplus ("charity"). See LOCKE, supra note 24, at 170 (bk. I, \$ 42). The controversy surrounding charity, however, makes it better to focus on the right against unjustified harm, and its relation to Locke's common.

131. See sources cited supra note 16

132. David Lange has placed at the top of the intellectual property agenda the question of how best to define and defend the public domain, and Locke's theory provides an interesting place to begin. See David Lange, Recognizing the Public Domain, 44 LAW \& CONTEMP. PROBS. 147-48, 171-78 (1981); see 


\section{Importance of a Common Heritage in Maintaining Expressive Capacity}

In a civilized society, human beings create the reality around them. Our direct surroundings are buildings and landscape architecture rather than woods and natural water. To be a creative maker of new meanings, ${ }^{133}$ a rational being needs access to her heritage. Just as land is necessary for farmers to bring forth fruit (in Locke's imagery), a common of previously-created intangibles is necessary for creators to bring forth new works of the imagination. Too broad a set of intellectual property rights gives one set of persons potential control over how that "created" reality can be interpreted. In other words, it can give them control over what the world means. Such control would deny others the understanding, or "naming," that is one crucial way humans interact with the world.

New creators inevitably ${ }^{134}$ and usefully build on predecessors. In her invention of techniques, discoveries, ideas, or themes, the new creator speaks out of a history, and the very value of her contribution will depend upon her advancing upon what has come before. The inventor of the automobile builds on one predecessor's invention of metal-smelting processes, another predecessor's invention of gears, another predecessor's invention of the wheel, and ultimately on the efforts of some Promethean cave-dweller who, in discovering how to make fire, laid the groundwork for the internal combustion engine. The pattern is not limited to the technological culture. Artists learn from predecessors the laws of perspective, the uses of oils, acrylics, and watercolors, and the very traditions that give meaning to their productions. As for music, it is often argued that there is a limited vocabulary available for musical composition, ${ }^{135}$ and that composers will inevitably and necessarily work in a received tradition, as well as re-use prior themes. Communication depends on a common language and common experience. Labor itself is guided and organized by anterior ideas. ${ }^{136}$

One cannot assume that early creators or their heirs would consent to the use of property by others to create new intellectual products if the first creators

also Jessica Litman, The Public Domain, 39 EMORY L.J. 965 (1990) (making several arguments that reinforce those made in this Article).

133. Adam's act of "naming" the animals, Genesis 2:19-20, is often used as a metaphor to suggest that the human ability to comprehend and give meaning to reality is a primary basis for mankind's rule over the animals. For suggestions that Locke shared this view of the importance of human rationality and creativity, see TULLY, supra note 82.

134. Some commentators (including a former Register of Copyrights) speak as if they think creators need use nothing at all out of the common stock. Ladd, supra note 37, at 426. But "Progress, if it is not entirely an illusion, depends on generous indulgence of copying." BENJAMIN KAPLAN, AN UNHURRIED VIEW OF COPYRIGHT 2 (1967). 82-86.

135. 1 Paul Goldstein, Copyright: Principles, LaW AND Practice 133, 224-25 ( 1989); 2 id. at

136. I am indebted to Allan Axelrod for this point. 
had control of these necessary prior resources. Some owners might consent to others' use without demanding compensation. ${ }^{137}$ Some might agree to compensated use. But others might refuse to sell altogether ${ }^{138}$ or charge more than the new creators can afford. More significantly, the cost of tracing ownership and effecting transactions could itself be prohibitive, ${ }^{139}$ particularly for fundamental ideas of fairly ancient origin, such as the discovery of perspective. For example, basic story ideas are fundamental building blocks in this way. From Romeo and Juliet to West Side Story and beyond, the plot in which children from warring factions fall in love has provided fruitful ground for a host of authors. Yet it took a twentieth-century decision of the Second Circuit Court of Appeals to make clear this story idea could not be owned. ${ }^{140}$ Had the decision been otherwise, who knows how many potential claimants could demand a toll from the next film producer to come along.

Thus, if perpetual property existed in all intangibles, many creators would have to choose between using someone else's property without permission, or forgoing creation of their own. Because of transaction costs, the possibility of transferring rights through the market would not help substantially. For new creators to flourish, they must be able to draw on an array of prior creations that are not privately owned.

\section{Intergenerational Equity}

Considerations of equity between generations mandate the same result. Later creators should be as free to use their faculties as their predecessors were, a liberty only possible if each generation is allowed some use of prior creations. An unencumbered freedom to attempt to describe and give meaning to reality-including that reality created by predecessor artists-must be granted to every potential artist lest she be "checkmated"141 by her predecessors. A painter in the state of nature who wants to depict her reality

137. For example, even if the inventor of the motion picture camera had a right to control any movies produced with his device, he might be willing to waive such claims in order to sell more cameras.

138. See Gordon, Jurisprudence of Benefits, supra note 10, at 1042-43 (using income effects to describe certain refusals to sell which are not value-maximizing in any meaningful sense).

139. Where the transaction costs of obtaining consent are high relative to anticipated gains, consent may be too expensive to obtain. See Gordon, Fair Use, supra note 11, at 1607-22, 1655-56 (discussing transaction costs as a cause of the market's failure to maximize value in the copyright context).

140. See Nichols v. Universal Pictures Corp., 45 F.2d 119 (2d Cir. 1930), cert denied, 282 U.S. 902 (1930) (movie Cohens and the Kellys held not to infringe the play Abie's Irish Rose, even if the former copied from the latter the idea of Irish and Jewish young people secretly marrying against their parents' wishes). Copying the detailed pattern of a story-as perhaps West Side Story copies the details of Romeo and Juliet-would be a different case. See 3 Melville B. NIMMER \& DAVID NIMMER, NIMMER ON

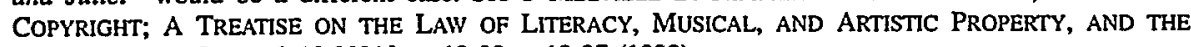
PROTECTION OF IDEAS $§ 13.03$ [A], at 13-32 to 13-37 (1992).

141. Courts are somewhat sensitive to the need to avoid giving a copyright that might later checkmate a subsequent creator from making full use of public domain ideas. See, e.g., Morrissey v. Proctor \& Gamble Co., 379 F.2d 675 (1st Cir. 1967). 
paints trees and caves. A painter in Renaissance Venice who wishes to depict reality will not only paint trees, but also the gondolas and buildings that others have created. When the age of modern copyright first arrived, a painter was free to depict what came before; her exercising that liberty should not close it off from others who come after her. A painter in the modern city should be as able as the cave painter to depict and interpret her surroundings, even if in the modern world many of the things she sees are artifacts created by others. That a first creator has labored is not sufficient ground to justify giving her a right to keep others from achieving their proper goals. ${ }^{142}$

The argument is of course not exhausted by the visual arts. A writer must be free to write about the effect of earlier writers upon her. ${ }^{143}$ Harold Bloom goes so far as to argue that all poetry involves a creative misreading of one's predecessors, ${ }^{144}$ so that, in a "sense, all poems can be read as rewritings of other poems." 145 Without some freedom to copy, later artists will lack the ability to describe their world that was enjoyed by their predecessors. ${ }^{146}$

\section{The Intangible Common}

Could Locke have foreseen a common of intangibles? A concern with human expressive capacities was central to his thinking. Locke built his theory largely around religious notions which highlighted human rationality and creativity as the source of man's claim of dominion over the earth's bounty. ${ }^{147}$ James Tully suggests that one of the "crucial point[s]" for Locke is that "everyone is able to labour in, and enjoy the fruits of, his calling in a manner appropriate to man, and analogous to God's activity as a maker."148

Thus, although the common explicitly discussed in the two Treatises was the physical realm - both that which existed already (land, seas, mountains) or that which was continually in the process of coming into existence without the assistance of humankind (deer, fish, acorns)-applying Locke's analysis to the

142. Wendy J. Gordon, Reality as Artifact: From Feist to Fair Use, 55 LAW \& CONTEMP. PROB. 93, 103 (1992). This point is further discussed infra Part II(D) (discussion of the proviso).

143. See Gordon, Jurisprudence of Benefits, supra note 10, at 1030-32 (arguing that past is at the center of many artists' work).

144. HAROLd BloOM, THE ANXIETy OF INFLUENCE: A THEORY OF POETRY 5 (1973).

145. TERRY EAGLETON, LITERARY THEORY: AN INTRODUCTION 183 (1983).

146. For an examination of how the human need to describe reality can translate into an expansion of the common, see Part II(D), infra.

147. See, e.g., LOCKE, supra note 24, at 291 (bk. II, § 34) ("God gave the World . . to the use of the Industrious and Rational ....").

148. See TULLY, supra note 82, at 169; see also id. at 6-7, 22, 38, 40-44, 65, 109, 116-22 (further developing this picture of mankind as maker). Note how Tully's view differs from the usual one which places Hegel and Locke at opposing ends of a spectrum, Hegel concerned with work as intrinsically valuable and Locke concerned solely with monetary outcomes. See, e.g., C.B. MACPHERSON, THE POLITICAL THEORY OF POSSESSIVE INDIVIDUALISM: HOBBES TO LOCKE 197-211 (1962) (suggesting Locke sought to justify class-based capital accumulation). 
intangible realm would not do violence to his thought. Admittedly, for the intangible reality of intellectual property, the common must be defined differently. The central criteria are the same, however: equality and need. Everyone has an equal right to use the common, and everyone needs to use the common for sustenance.

The most obvious component of the intangible common is equivalent to what our law now identifies as the "public domain": those intellectual creations already in existence but not privately owned. In American law, the public domain is largely filled with creations whose period of protection has expired, works which have been abandoned, or works for which no protection existed $a b$ initio. Similarly, if there are works which, under Lockean principles, would have only limited duration or would not be capable of being owned, ${ }^{149}$ they would be part of the common.

\section{The Common as Property}

For Locke, the word "property" embraces virtually any liberty or claim to which one was entitled under the law of nature. ${ }^{150}$ The public's liberty to use the common is a species of property in even a stronger sense, for as a "liberty right" ${ }^{\prime 151}$ it is a stable and guaranteed entitlement. Admittedly, this Lockean entitlement does not entitle us to force others to assist us in using the common resource. Rather it defines an area in which one is entitled to be free from the restraint that others' property rights impose. ${ }^{152}$

It is conceptually untenable to treat "property" and "liberty" as if they were fully separate categories. Every conventional private property right contains a "liberty to use,"153 and some liberties are public property strong

149. General ideas are not capable of being owned in a Lockean system. See infra Part II(F)(2). Many other new creations cannot be fully owned, and those parts that remain unowned fall into the common. See infra Part II(D). As for duration, Robert Nozick suggests that a less-than-perpetual property right in inventions is mandated by Lockean theory. He argues that the right to the common would be violated if an inventor were given a perpetual property interest in an invention which, over time, another inventor would have come upon. See NozICK, supra note 72 , at 181-82.

150. See, e.g. White, supra note 33, at 285 (At one point in his writings, "Locke identifies the idea of property simply with the idea of a right," and his other usages may simply be illustrations of that basic conception.). Admittedly, it is customary to distinguish Locke's usage of the term "property" in this extended mode from his usage of the term "property" meaning "material possessions." See, e.g., Laslett, Introduction to Locke, supra note 24 , at 3, 102. But as Laslett admits, "property" for Locke "seems to symbolize rights in their concrete form." Id. at 103.

151. See supra note 46 (defining "liberty right").

152. For constitutional purposes the United States Supreme Court also sometimes treats liberties as property when they are not merely interfered with by some private party, but abrogated and transformed into duties by governmental act. Thus, completely eliminating a property owner's economically valuable liberties to use her land would be a "taking" under the Fifth Amendment. See Lucas v. South Carolina Coastal Council, 112 S. Ct. 2886, 2892-94 (1992). Cf. Wisconsin v. Constantineau, 400 U.S. 433, 436 (1971), as interpreted by Paul v. Davis, 424 U.S. 693, 707-09 (1976) (state action depriving person of liberty to purchase liquor was an alteration of legal status that, when coupled with injury from state's defamatory statement, must meet Due Process Clause requirements).

153. See, e.g., 17 U.S.C. $\$ 106$ (1988) (copyright includes right to "do" enumerated acts as well as 
enough to keep conventional private property from forming. Illustrating the latter category is a recent pre-emption case, in which the Supreme Court decided that the patent law not only created private rights in patentees, but also created certain liberties of use in the public. ${ }^{154}$ These liberties were entitlements that no state could undo-and to preserve them the court struck down state laws imposing duties not to copy certain intellectual products. ${ }^{155}$ Similarly, the common would be an enforceable "right to use" inhering in the public, and thus property.

Regarding the nature of this property in the common, Locke says that Adam's many descendants individually had a right to possess and use as much as was needed to "provide for their Subsistence,"156 with certain duties attaching. His text suggests that he had in mind a property entitlement of the following sort: each of us (1) has a justified liberty to use the common, (2) subject to no duty (absent charity or waste) to account to our co-owners for any profit or product we make out of the common, (3) coupled with a duty not to deplete our co-owners' ability to use the common. ${ }^{157}$ What Locke posits is a sort of compromise, an entitlement midway between nonownership and tenancy-in-common: freedom to keep one's gains, subject to a duty not to impair others' abilities to draw their own gains from the resource.

The preservation of this public property right raises a critical problem. All persons in the state of nature have a liberty right in the common. But private property also exists in the state of nature, and such property involves a claim right over third parties. Thus, the public will sometimes have duties that conflict with its entitlement to the common.

\section{Conflicts Between the Laborer's Claims and the Public's Entitlement in the Common: The Proviso}

Which entitlement takes priority in cases of conflict? In circumstances where the laborer's claim to deserve property would, if honored, impose duties on others restricting their use of the common, should those duties nevertheless be imposed, or should the laborer's claim to exclusive property be invalid?

\footnotetext{
right to exclude others from doing them). Privileges of use constitute part of most standard definitions of property rights. See, e.g., BRUCE ACKERMAN, PRIVATE PROPERTY AND THE CONSTITUTION 99-199 (1977); Gordon, Merits of Copyright, supra note 10, at 1354-77 and sources cited therein (defining property in tangible and intangible contexts).

154. Bonito Boats, Inc. v. Thunder Craft Boats, Inc., 489 U.S. 141, 165 (1989) (stressing that "the federal patent laws do create a federal right to "copy and to use"').

155. Id. (state law prohibiting use of direct molding process to duplicate unpatented boat hulls held preempted).

156. LOCKE, supra note 24, at 206 (bk. I, § 87).

157. The last-mentioned duty is discussed at Part II(D), infra.
} 
Locke is not willing to favor the laborer's claim automatically under these conditions, ${ }^{158}$ and his hesitation is well founded. When the common is threatened by a laborer's claim to property, it seems right that the laborer cannot use the moral law to restrain the common's use. Yet because the products are only partially drawn from the common, and are partially drawn from the laborer's own effort as well, it seems right that the public cannot use the moral law to force the laborer to share. The two claims are in apparent stalemate.

To understand how Locke resolves the stalemate, recall how the laborer's claim to deserve property is itself justified. ${ }^{159}$ That claim is premised on two primary elements: an assumption that to take the product of the laborer's effort is to cause harm to the laborer, ${ }^{160}$ and the law of nature that all persons have a duty to refrain from causing harm. ${ }^{161}$ But the same no-harm principle dictates that the laborer should not do harm to other peoples' claim to the common. ${ }^{162}$ When the two conflict, the common must prevail. Were the result otherwise, the natural law would grant laborers a claim right to do harm, reversing Locke's first law of nature that no harm be done.

It is bad enough when a private party does harm and violates the law of nature. But it would be worse for the law of nature itself to grant a claim right to do harm (and to impose the correlative duty, to accept harm or impose harm on oneself). Further, the logic of the property owner's initial claim gives priority to a no-harm principle. If the property claim itself would do harm, it cannot be enforced without raising additional problems of justification-problems which are not solved by Locke's account. ${ }^{163}$

158. See LoCKE, supra note 24 , at 288 (bk. II, § 27) ("For this Labour being the unquestionable Property of the Labourer, no Man but he can have a right to what that is once joyned to, at least where there is enough, and as good left in common for others.") (second emphasis added).

159. See supra Part II(B)(1). It is common to interpret Locke's property theory as a theory of desert, e.g., David Miller, Justice as Property, RATIO 22 (1980); BECKER, PROPERTY RIGHTS, supra note 67, at 43-45, and I take a similar interpretive view here. However, that judgment is not unanimously shared. See WALDRON, supra note 59, at 201-07 (arguing that Locke's theory is not a theory of desert). Waldron also has a different perspective on the proviso than that advanced here. See id. at 207-18.

160. Thus Olivecrona argues that for Locke, "when the object [appropriated] has been included within [the] sphere [of the personality], it will be an injury to the possessor to deprive him of it." Olivecrona, supra note 55 at 223; see also id. at 211,219-20, 221-26 (fruits of labor perceived by Locke as an extension of laborer's personality and, as part of this sphere of personality or "suum," to be protected from harm); see also Olivecrona, Term "Property", supra note 68 at 112-14 (1975) (discussion of the "suum" in natural rights theory).

161. See supra note 49 and accompanying text.

162. For an elegant development of the argument that positive desert claims must also take note of negative desert, see, e.g., BECKER, PROPERTY RIGHTS, supra note 67, at 42-43, 51; see also LAWRENCE BECKER, RECIPROCITY, 74, 101-30 (1986) (not only should "good received . . be returned with good," but "evil done should be made good" via restitution).

Note however that unlike Becker, I do not broaden the proviso to embrace a protection against any kind of harm.

163. For similar arguments in the restitution context, see Gordon, On Owning Information, supra note 10 , at $207-10$. 
Thus no natural right to property could exist where a laborer's claims would conflict with the public's claim in the common. ${ }^{164}$ One could argue for a different result. Perhaps at the point of conflict in the structure of natural entitlements, natural law could give way to other, prudential considerations, like economics. For example, prudential considerations might justify a particular right to property where natural law would not. Whether in cases of conflict natural right would forbid the creation of entitlements premised on bases other than the natural law itself is an issue Locke did not reach and this Article will not address. Locke's own resolution is to declare the conditions under which a natural right to property is justified: if there is "enough, and as good left in common for others" after the appropriator has taken up his share, ${ }^{165}$ then no one has grounds for complaint. ${ }^{166}$

This is Locke's famous proviso, and it plays a crucial role both in the Lockean justification for property, and in resolving the conflicts that can arise between a laborer's property claims and the public's entitlements. Applying it to conflicts between the laborer's and the public's rights establishes that no duties (and thus no claim rights) arise where conflict exists: neither party can use the natural law to restrain the other, and both parties have liberties of use. Consequently, in cases of conflict, the public's liberty right in the common prevails.

\section{Defining the Proviso}

Locke states the proviso thus: "Labour being the unquestionable Property of the Labourer, no Man but he can have a right to what that is once joyned to, at least where there is enough and as good left in common for others." 167

With the proviso, Locke argues that one person's joining of her labor with resources that God gave mankind ("appropriation") should not give that individual a right to exclude others from the resulting product, unless the exclusion will leave these other people with as much opportunity to use the common as they otherwise would have had. A person who wants access is entitled to complain only if he is worse off (in regard to the common) when

164. But see WALDRON, supra note 59, at 207-18 (rejecting the "traditional interpretation," id. at 210.

165. Locke, supra note 24 , at 288 (bk. II, § 27).

166. Id. at 291 (bk. II, § 34); see also id. at 291 (bk. II, § 33) "Nor was this appropriation . . . any prejudice to any other Man, since there was still enough, and as good left ... For he that leaves as much as another can make use of, does as good as take nothing at all."

For a far-ranging discussion of the impact of the proviso on property, see A. JOHN SIMMONS, THE LOCKEAN THEORY OF RIGHTS (1992), particularly at $\$ 5.4$. (Unfortunately this book was published too recently for me to consider Simmon's arguments here.).

167. Id. at 288 (bk. II, § 27) (second emphasis added). It is not clear from Locke's text whether he meant "enough, and as good" to function as a precondition to the formation of property, or whether he meant simply to reserve for later study whether property could evolve where "enough and as good" was not available. I take the former, stronger view and argue in this Article that property's exclusion rights are not a reward justified under the natural rights approach, except where the proviso is satisfied. 
he is denied access than he would have been if the item had never come into existence. If the proviso is satisfied, others are no worse off if they are excluded from the resource the laborer has marked off as her own. ${ }^{168}$

Natural law writers before Locke had long struggled with the problem of how to justify individual property rights and still give due deference to the rights of the rest of mankind. ${ }^{169}$ Pufendorf's solution was to suggest that all persons consented to others' property rights. ${ }^{170}$ This argument, however, was ridiculed by Sir Robert Filmer, a strong advocate of the divine right of kings. In Filmer's view the very impossibility of obtaining such consent helped to show that mankind as a whole did not have common rights in the earth, and that the earth had instead been given to Adam and Adam's proper heirs-the monarchy. ${ }^{171}$ In turn, Filmer's alternative was anathema to Locke. Indeed, refuting Filmer, and defending the common ownership of the earth's bounty, was the primary point of Locke's First Treatise. Yet Locke did not deign to use Pufendorf's argument that all mankind consented to each act of appropriation. ${ }^{172}$ Locke's own solution is more elegant. He specifies a ground for justifiably dispensing with consent: if there is "enough, and as good left in common for others" after the appropriator has taken up his share, ${ }^{173}$ then the appropriation "does as good as take nothing at all."174

The proviso that "enough and as good [be] left" lies at the center of this Article's thesis: that creators should have property in their original works, only provided that such grant of property does no harm to other persons' equal abilities to create or to draw upon the preexisting cultural matrix and scientific

168. LockE, supra note 24, at 291 (bk. II, § 34). By "worse off," then, I am following Locke's choice of baseline: making a comparison between the nonowner's level of welfare in a world where the putative owner had not labored, and the nonowner's welfare in a world where the owner has labored and has a right to exclude others from what he has produced. See Gordon, Merits of Copyright, supra note 10, at 1446-65 (baselines in intellectual property).

169. See Olivecrona, supra note 55, at 215-17 ("Since men were equal it was impossible to understand how the mere physical act of occupation could have the effect of excluding others from an object.").

170. Id.

171. See generally SIR Robert FILMER, PATRIARCha AND OTHER POLITICAL WORKs (Peter Laslett ed., 1949).

172. Locke, supra note 24 , at $285-86$ (bk. II, $\S 25$ ). "If such a consent as that was necessary, Man had starved, notwithstanding the Plenty God had given him." Id. at 288 (bk. II, $\S 28$ ). Locke does, of course, use consent in other contexts-most notably, as the basis for the foundation of civil government. But the crux of the consent to civil government is not whether people actually consented, but rather whether the government deserves consent in terms of serving the interests of the governed. See Pitkin, Obligation \& Consent I \& II, supra note 44. This argument-that all an institution needs for legitimacy is to serve the self-interest of the persons it affects-could not as easily be used to justify private property; one person's property does not necessarily serve the interests of all others.

173. Locke, supra note 24 , at 288 (bk. II, § 27).

174. Id. at 291 (bk. II, § 33). 
heritage. All persons are equal ${ }^{175}$ and have an equal right to the common. ${ }^{176}$

It is important to understand several things about the proviso. First, the proviso does not allow property to form merely because it is "efficient" or otherwise serves the social good. Even if a grant of property might be desirable from these various points of view, natural law forbids it if recognizing a property right would significantly reduce third parties' ability to use the common. ${ }^{177}$ Conversely, if the proviso is satisfied, the theory allows property to form regardless of whether a nonproperty status would better serve social goals such as efficiency.

Second, the proviso only offers limited protection for members of the public. Persons whose rights in the common are not adversely affected by the creator's property right would have no ground of complaint, and the creator could assert property rights against them unimpeded. Further, even as to the individuals whose freedom from property-based restraints may be guaranteed by the proviso, the proviso gives such individuals no entitlement to affirmative societal intervention on their behalf.

Third, the proviso treats only one kind of harm as relevant for propertyformation purposes: it protects the propertyless from depletion of the common. While Locke posits that persons should in general refrain from doing harm to one another, the proviso is not written this broadly, nor should it be interpreted in this way. Harms to interests outside the common would not invalidate property under the proviso. ${ }^{178}$

175. One might try to argue that the laborer's very efforts distinguish him from other persons. Note, however, the identity of the third parties with whose welfare Locke is concerned: neighbors or strangers who themselves wish to apply their effort to the common. As between equally industrious persons, the facts that one may be born first and thus have earlier access to the common is not a morally relevant ground for distinction.

176. Compare the argument of Judge Benjamin Kaplan: "[I]f man has any "natural" rights, not the least must be a right to imitate his fellows, and thus to reap where he has not sown. Education, after all, proceeds from a kind of mimicry ...." KAPLAN, supra note 134, at 2. Cf. Justin Hughes, The Philosophy of Intellectual Property, 77 GEO. L.J. 287 (1988) (critiquing and applying both labor and personality justifications for intellectual property).

177. There may be an exception for extreme situations. Under Locke's "charity," a private property owner's nonessential resources (her "surplusage") must be given to someone who is starving to keep him from death. Analogously, if in an instance allowing private property to arise would save lives, perhaps that property could properly arise even if it required the sacrifice of a nonessential part of the common.

178. It has been much debated whether the proviso embraces competitive harm. Thus, Nozick argues that the proviso "does not include how I 'worsen' a seller's position if I appropriate materials to make some of what he is selling, and then enter into competition with him." NozICK, supra note 72, at 178. But see BECKER, PROPERTY RIGHTS, supra note 67 , at $42-43$, who argues that the proviso would protect against all harm, including competitive harm.

In my view, little hangs on this argument. Even if competitive harm is not implicated by the proviso, it may come within the broader protection of Locke's no-harm rule. But either outcome would not significantly change the analysis, for commercial interests are largely fungible and capable of being fully compensated by monetary benefit. It is highly likely that when the positive law fails to protect businesses against ordinary losses resulting from competition, we are all more than repaid by the extra product that flows from the operation of a competitive economic system. If so, allowing a privilege of competition would be consistent with natural law, regardless of whether there is a prima facie natural right against competitive harm. 


\section{The Role of the Proviso in Justifying and Limiting Property}

Criticism of a theory of property is likely to come from two quarters: from property owners who feel the theory is too narrow in its grants of title, or from those among the propertyless who object to finding themselves barred from resources and goods which they desire. In Locke's theory, the proviso serves as Locke's bedrock response to the complaints of the nonpropertied. ${ }^{179}$ As Judith Jarvis Thomson has asked, if "enough and as good" is truly left, how could the proviso "fail to be" a sufficient condition for property acquisition? ${ }^{180}$ If the proviso is satisfied, creating property gives the laborer a reward (and creates socially useful incentives, to boot) at no cost to the fundamental human entitlements of the nonpropertied in the common.

It is the proviso therefore that gives Locke's theory much of its moral force. ${ }^{181}$ Locke here takes a step that helps to justify an exclusion right, for, with the proviso satisfied, the public's fundamental entitlements will not be impaired if the owner excludes it from the owned resource.

The proviso has additional functions within Locke's argument. For example, the proviso usefully limits the amount of property that can be claimed by an individual. A principle that property results from mixing labor with the common could be absurdly overbroad. Thus Robert Nozick has asked "if I own a can of tomato juice and spill it into the sea ... do I thereby come to own the sea, or have I foolishly dissipated my tomato juice?'”22 Once the proviso is added, Nozick's hypothetical is no longer problematic: oceans may not be owned without violating the proviso, but smaller claims may be justifiable. Thus, today there are artists whose work consists of stringing fences or wrapping areas of landscape. Suppose such an artist stirs some tomatocolored dye into a bay and changes its color to complement the sunset. The artist would seem entitled to keep everyone else out of the colored area to preserve his handiwork from being marred by eddies and diluents, provided that the world offers the other ocean users-boaters, swimmers, aestheticians-equally good and convenient areas of ocean for their use.

The desert basis for such "property" may be trivial, depending on one's view of this sort of art, but if the proviso were satisfied, the claims of those who would want to disrupt this particular patch of ocean would seem even

179. Locke also responds to the claims of the nonpropertied by the encumbrance against waste, and the obligation of charity. The proviso, however, serves as the most important response.

180. Judith J. Thomson, Property Acquisition, 73 J. PHIL. 664, 666 (1976). The rhetorical question could be less than persuasive to, for example, someone who treated individual abilities as a pool in which we all have ownership. From the individualistic premises of Locke, however, Thomson's question yields only one likely answer.

181. See GAUTHIER, supra note 85 , at 193 ("[A]dherence to the proviso introduces a structure of rights into a previously non-moral state of nature . .."); see also NozICK, supra note 72 , at 178.

182. NoZICK, supra note 72 , at 175 . 
more trivial. ${ }^{183}$ If there were equally direct and scenic routes available elsewhere, one would probably disapprove of a prankster's deliberately driving his motorboat through the artwork, and think it appropriate for the artist to receive a permit and the aid of a park official in a governmental motor boat to help head off intruders.

Ordinarily we imagine that it is the property claimant who has to justify why the law should aid him in excluding other people from his domain. But if no one's baseline position is worsened by a grant of property, then it is the would-be entrant or user who bears the burden of explanation; he should be required to show why a laborer's property claim should not bar him.

Locke suggests the following test for determining whether the proviso is satisfied: a covetous and contentious stranger has no justification to complain of another's taking possession and ownership of land if, after the owner's appropriation, "there was as good left, as that already possessed, and more than he [the envious complainer] knew what to do with, or his Industry could reach to." 184 Since the number of potential intellectual products is not limited by physical constraints-the globe may be entirely taken up, but new intellectual products can continue to be made-it might be argued that intangible creations easily pass Locke's test. Even if the creative laborer receives exclusive property in them, there will always be more possibilities open to strangers than they "kn[ow] what to do with."185 At the outset, then, the creation of virtually all intellectual products seems to meet Locke's test, and the proviso might appear to impose no constraints on intellectual property formation whatsoever.

Many commentators have indeed suggested that intellectual property rights cost no one anything. For example, Steven N.S. Cheung recently traced the "something-for-nothing" thesis from Jeremy Bentham, through J.B. Say and John Stuart Mill, to J.B. Clark, and applied it to patents: "If the patented article is something which society without a patent system would not have secured at all - the inventor's monopoly hurts nobody ... his gains consist in something which no one loses, even while he enjoys them." ${ }^{186}$ That is, if $A$

183. Note that the proviso does not fully solve the problem that a little bit of effort, well placed, may still earn a creator a disproportionate amount in revenues. Nevertheless, though a creator has no clear moral claim to a windfall profit, a stranger who has done no creating at all hasseven less claim to reward. If in addition the creator's having a right to the profit makes the stranger no worse off in any relevant way, the stranger would be hard put to state a claim to share in the revenues. Thus, Lawrence Becker says that "[i]t is not so much that the producers deserve the produce of their labors. It is rather that no one else does ...," BECKER, PROPERTY RIGHTS, supra note 67, at 41; see also Robert C. Denicola, Institutional Publicity Rights: An Analysis of the Merchandising of Famous Trade Symbols, 62 N.C. L. REV. 603, 640-41 (1984) (arguing no one has better claim to trademark's commercial value than its producer).

184. Locke, supra note 24 at 291 (bk II § 34).

185. Id; see Hughes, supra note 176, at $300,315-23$ (suggesting that ownership of most intellectual products will easily satisfy the proviso though "extraordinary ideas" like generic trademarks, $i d$. at 321-22, should remain open for all to use.)

186. Steven N.S. Cheung, Property Rights and Invention, in 8 RESEARCH IN LAW AND ECONOMICS: The ECONOMICS OF PATENTS ANd Copyrights 5, 6 (John Palmer \& Richard O. Zerbe, Jr. eds., 1986). 
makes something that did not exist before, excluding $B$ from using it will arguably leave $B$ unharmed. In Lockean terms, the claim is that because $B$ still has free access to the same public domain elements that $A$ had, her ability to use the common is unimpaired.

If indeed a creative person creates something, and denying others access to it imposes no costs on the latter, then giving the creator rights of exclusivity would seem justified. But there is no reason to suppose that rights to intangibles invariably conform to this pattern. Mill was wrong to suggest that no one ever "loses" by being prohibited from "sharing in what otherwise would not have existed at all."187 That an intellectual product is new, would not have otherwise existed, and may initially bring benefit to the public, does not guarantee that later exclusions from it will be harmless.

Tort law has long recognized that once action has begun, inaction can result in harm, not merely in the failure to confer a benefit. ${ }^{188}$ Analogously, once a creator exposes her intellectual product to the public, and that product influences the stream of culture and events, excluding the public from access to it can harm. For example, assume that $A$ takes substances from the common from which, with great ingenuity, she manufactures an enzyme that greatly improves one's health. Because of its salutary properties, a decision is made to include the enzyme in the drinking water. The benefits, however, come at the cost of a particular form of addiction: some people who drink the enzyme become unable to metabolize carbohydrates without continued intake of this elixir. To people so affected, ordinary food becomes valueless for nourishment-it is useless unless eaten along with the enzyme. In such a case, the fact that the common continues to have an ample supply of both food and the elements from which the enzyme can be made is not sufficient to protect the public from harm. The addicted public also needs $A$ 's knowledge of how the enzyme is manufactured, for without it, they will starve in the midst of plenty. If, after the enzyme is put into the water supply, the inventor is given a right to prohibit others from using her manufacturing technique, addicted members of the community are worse off in their ability to use the common than they were before.

Thus, the mere presence of abundant raw materials would not suffice to give $A$ a right to exclude $B$ and other strangers from the enzyme or from learning how it can be made. Giving $A$ ownership of the enzyme or a patent

Cheung goes on to note that contemporary economic scholarship recognizes that the patent system imposes significant social costs. Id.

187. John StUART Mill, PRinciples of POlTtCal ECONOMY 142 (1872).

188. See Nallan v. Helmseley-Spear, Inc., 407 N.E.2d 451, 460 (1980) (quoting H. R. Moch Co. v. Rensellaer Water Co., 159 N.E. 896, 898 (1928) (Cardozo, C.J.) (dicta)). Similarly, if someone leads others to rely on her, she may have a duty not to absent herself. See Farwell v. Keaton. 240 N.W.2d 217 (1976) (if two parties embark on an adventure with an understanding of mutual aid, one may not be at liberty to abandon the other). A similar reliance argument underlines the doctrine of promissory estoppel. See infra Part II(F)(1) (congruence with contemporary legal structures) for further discussion. 
over its method of manufacture would leave the proviso unsatisfied, for even if $A$ 's appropriation leaves "as much" for others, it does not leave "enough, and as good." Mere quantitative identity is not enough. This is essentially a reliance argument: having changed people's position, the inventor cannot then refuse them the tools they need for surviving under their new condition.

Consider for example the position of an early mathematician. Once Arabic numerals are introduced into her culture, it will be virtually impossible for her to make significant contributions to mathematics if she is limited to the public domain of Roman numerals. For the later mathematician to be able to use her knowledge and her faculties as well as she could have prior to the invention of the new numbering system, she would need access to the new system that someone else has developed. Or suppose a politician gives a speech that made promises upon which the public relies; if the promises turn out unfulfilled, it may be necessary to quote the promises in order to mobilize the appropriate political reaction. If quotation is forbidden, the speech-however consensually listened to in the first instance-may do the public irremediable harm. More generally, if someone tells lies, it may be necessary to quote those lies to rebut them more effectively and to protect oneself and one's friends. Or consider a landscape photographer. As each bit of the natural landscape is replaced by buildings, statues, and other human artifacts, the only way her interest in the common can remain "as good" is if she is given the freedom to photograph her new surroundings.

Finally, suppose a preacher instructs his flock to follow precepts that he claims are based on divinely inspired writings, and his audience does in fact follow these rules. Perhaps the precepts contain a ban on birth control, or perhaps a general ban on seeking the help of doctors. If some of the congregation begin to doubt these guidelines, they need to be able to resort to the original text on which the preacher relied to judge for themselves whether the restrictions are justified. If the doubters in the congregation cannot quote, print, and distribute to like-minded persons the portions of the writings that suggest the preacher's interpretation is not the only or best one, the doubters and those whose interests they serve are harmed. That is, if the preacher is empowered to forbid any unauthorized translations or unauthorized set of excerpts from these scriptures, it may happen that the congregation may be worse off having been exposed to the "authorized" version than if they had initially been left to their own resources to find a source of moral guidance in the common.

Texts much less important than scriptures can also have a grip on the mind that only use of the original can shake. Perhaps an advertiser saturates the airwaves with a cute little symbol (the Eveready bunny or the Pillsbury dough boy) which come to have a deep impact on children viewers. Should those children, once adult, want to free themselves and people like them from the consumer culture that surrounded their growing years, they may wish to use 
those images satirically, out of context, to try to break the chain of "charming" associations that would otherwise determine the symbols' psychological effects. Should these former audience members and those they serve not be able to play with the symbols that formed their mental vocabulary, they may be worse off than if they had initially not been exposed to them.

Moreover, a prohibition on copying can cause harm even when the audience has no complaints whatever about the artifact to which they have been exposed: it is possible to become addicted even to beneficial mental substances, and all addictions carry with them the possibility of harm. Some poems, some ideas, some works of art, become "part of me"189 in such a way that if I cannot use them, I feel I am cut off from part of myself. I would prefer never to have been exposed to them rather than to experience that sort of alienation.

Consent does not eliminate the problem. In a pervasive media culture there will always be "seepage"190_ some ideas and some images will impinge on one's consciousness whether or not one has sought them out. Even in cases of express consent, as when someone pays money to enter a movie theater, there is no guarantee that a prohibition on copying will do no later harm. When someone agrees to expose herself to a new cultural artifact, she cannot know how it will affect her in advance. An audience may be told that it will be forbidden to copy what it is about to see, and the members of the audience may nevertheless agree to see it and even pay to see it. But it may live to regret the bargain as ultimately ill-informed.

Being forbidden to copy thus may require one to choose between silence and deception. An early twentieth-century psychologist may read Freud and be convinced that the ego-id-superego structure well describes the organization of the human psyche. If such a researcher were forbidden to use those concepts in her books, however, she might be left with no way to describe honestly her beliefs about human nature. She can use evasion (and injure her scholarship), not publish (and nullify her scholarship), or violate the prohibition. At that point she might well wish to exchange her post-Freud expanded understanding for intellectual freedom - but she cannot; she cannot unlearn what she now believes to be true.

This example may seem far-fetched, for in our country ideas like Freud's cannot be owned and are therefore in the public domain for all to use. But part of the reason general ideas are not ownable under current law is precisely because there is a Lockean concern with protecting the public from harm. ${ }^{191}$ For visual artists, the public domain of current law is not as accommodating as the Lockean spirit would imply. Images that capture artists' attention and

189. J.S.G. Boggs, Who Owns This?, 68 CHICAGO-KENT L. REv. (forthcoming 1993).

190. The phrase is Jessica Litman's; see Litman, supra note 132.

191. See infra Part II(F)(2). 
become "part of them" are often owned by others. And when an image or poem captures the artist, he or she may be unable to create except on the agenda it sets. As artist J.S.G. Boggs has observed:

Creative people are prisoners. That is to say that they get "captivated", and the only way out is to beat a path away from the point of captivity. If my attention is "captured," it is impossible to simply get away. The bars are not physical. They are produced by the intellectual, the emotional, or, more usually, a combination of the two. But, they are as functional as any jail cell you will ever construct in the material world. . . ${ }^{192}$

In sum, if there is only one culture (and whether technological or literary culture is at issue, the point is the same), a person who wishes to contribute to it usually is required to use the tools of that culture. Giving first creators ownership over any aspect of the culture, even if that aspect is newly created, may make a later creator less well off than he or she would have been without the new creation. Intellectual products, once they are made public in an interdependent world, change that world. To deal with those changes, users may have need of a freedom inconsistent with first creators' property rights. If they are forbidden to use the creation that was the agent of the change, all they will have to work from will be the now devalued common. The proviso eliminates this danger. It guarantees an equality between earlier and later creators. The proviso would thus ensure later comers a right to the broad freedom of expression, interpretation, and reaction which earlier creators had, a right which cannot be outweighed by other sorts of benefits.

\section{Individualized and Nonfungible Nature of the Proviso's Protection}

This Article will treat the proviso as establishing an "individualized" criterion. In other words, the Article argues that a later arrival on the cultural scene should be at liberty to use an existing creation if prohibiting his own use would make him worse off individually than he would have been if the predecessor creator had not created the intangible at issue. This is a somewhat controversial interpretive step to take. Many commentators have interpreted Locke's proviso as imposing only an "aggregate" condition, as if Locke had written something like "a laborer's appropriation results in property as long as the institution of property, on the whole, leaves nonappropriators better off than they would have been in a world without property rights." From this premise, it seems to follow readily that the proviso is permanently satisfied by the extensive benefits generated by a market economy. ${ }^{193}$ C.B. MacPherson,

192. Boggs, supra note 189.

193. Some proponents of the view that economic benefits can compensate for erosion of the common 
for example, views the proviso roughly along these lines, and he uses his interpretation to argue that Locke was not concerned with the welfare of the nonpropertied. ${ }^{194}$ Clearly a proviso this easily satisfied is tantamount to no proviso at all. But this should provide evidence that the aggregate interpretation is wrong.

There are two possible tacks an aggregative approach can take. First, one might think that Locke would accept erosion of the common so long as the net social welfare increased. This interpretation, however, ignores Locke's concern with individuals. Consider, for example, his focus on what "each" of us inherits. Locke's First Treatise was written primarily as an attack on Sir Robert Filmer, an advocate of the divine right of kings. ${ }^{195}$ Locke's reasoning involved an attack on primogeniture, and a defense of all individuals' rights to survive and inherit. ${ }^{196}$ Further, the individualistic foundations of Locke's starting assumptions would not seem to allow for routine trade-offs between persons. ${ }^{197}$

As a second possibility, an aggregative exponent might assume that all resources are fungible, so that giving economic benefit to an individual would always compensate her for her loss of the common. But Locke distinguishes between ordinary resources which are bought and sold, and goods like freedom that are essential to human nature. The latter are inalienable ${ }^{198}$ they cannot be transferred no matter how much their possessor desires to do so, and no matter what benefit is offered in exchange for them. A fortiori, in property formation, where nonowners do not even consent, things essential to life cannot be fenced off from any individual who needs them, even if some other kind of benefit is given in exchange.

The second version of the aggregation argument ignores the problem of exchanging inalienable benefits because it assumes that the benefits the proviso

nevertheless take an individualized approach to such compensation. See Geoffrey P. Miller, Economic Efficiency and the Lockean Proviso, I0 HARV. J.L. \& PUB. PoL'y 401 (1987).

194. See MACPHERSON, supra note 148, at 211-20. James Tully makes a convincing case that, in attributing to Locke a justification for "unlimited individual appropriation" and an indifference to "social obligations," MacPherson misunderstands Locke's position. See TULLY, supra note 82, at 131 .

195. Laslett, Introduction, in LOCKE, supra note 24 , at 50-51, 67.

196. LOCKE, supra note $24,204-05$ (bk. I, $\$ \$ 84-93$ ) (opposing primogeniture, $i d$. at 209 , $\$ 91$, and defining the "public good" as "the good of every particular Member of that Society, so far as by common Rules, it can be provided for," id. at $210, \S 92$ ). It should be noted that Locke also sometimes speaks as if individuals are not the sole concern. Thus, he notes that the fundamental law that is to govern "even the Legislative it self, is the preservation of the Society, and (as far as will consist with the publick good) of every person in it." LOCKE, supra note 24, at 356 (bk. II, \$ 134) (emphasis altered). Whether Locke here meant he would be willing to trade the natural rights of one for the welfare of the many depends, inter alia, on the meaning he gave to "publick good." If by "publick good" he had in mind preservation of individuals" natural rights, this sentence would simply mean that the Legislature is not bound to preserve the lives or freedom of persons who break the law of nature.

197. See supra Part II(A).

198. See LOCKE supra note 24, at 284 (bk. I, § 23); see supra Part II(B)(2)(b) (the power of transfer). Note I am offering here an argument that generalizes Locke's inalienability argument beyond the basic goods (freedom) he discussed. 
protects are fungible with other benefits. If they are fungible, then property can form even if the proviso is violated, so long as the property rights create an aggregate economic benefit for the individual excluded from the owned good. ${ }^{199}$ This may be an acceptable argument for some parts of the common, like land. But not all costs and benefits can be measured in a common coin. Much in the common of intangible products is not fungible with ordinary economic goods. ${ }^{200}$ There is little, for example, that could compensate for loss of freedom of expression.

The protection the proviso gives free speech is thus both individualized and nonfungible. Summarizing that protection as a whole we find: (1) The proviso protects peoples' liberty to use what has already been created and is in the public domain. Nothing can be taken from the public domain unless "enough and as good" is left. (2) If a new creation renders the public domain less valuable, the proviso gives people a privilege to use the new creation to the extent necessary to make themselves as well off as they previously were. Among other things, this means that major cultural developments must be open for all to use. (3) The proviso gives people the same kind of liberty to create that they would have had if the creators had not sought to appropriate. As one application of this principle, persons have the liberty to use what they would have discovered in the absence of prior creators. As a broader application of this principle, persons have the liberty to deal with reality as fluidly and freely as if prior creators had not existed.

\section{E. Natural-Right Rewards Other than Property: The Proviso in an Ideal World}

In an ideal world we could minimize conflicts between the public's entitlement in the common and the laborer's claim to desert. Although Locke for historical reasons ${ }^{201}$ concentrated on whether full property rights were justified, nothing in his Treatises indicates the laborer forfeits all claims to deserve reward in cases of conflict between the laborer's claim to property and the public's entitlement in the common. True, the laborer loses her claim to property in such cases. But perhaps she still deserves reward under natural law,

199. See MACPherson, supra note 148, Miller, supra note 193 for arguments of this sort.

200. I do not reach the issue of whether an intellectual property system might create an "in-kind" compensation for the communicative rights it inhibits. Even if this were possible-that increased numbers of new ideas could compensate for prohibitions in the use of existing ideas-most intellectual property systems do not aim only at such crucial goods. The typical bestselling potboiler is unlikely to contain in it anything capable of compensating for loss of rights in expression.

201. Locke's project was concerned more with politics than with property. If Locke could "prove" that the public had some property prior to the birth of the civil state, and that the public created the state to protect this property, then those owners are entitled to the state's providing the intended protection. If the state instead abuses the public's rights, Locke's analysis suggests, that is a ground for justified revolution. 
and perhaps a reward that is less than full property can be given to her that leaves the public "enough and as good."

In a world containing an all-seeing administrative eye and transactioncostless computers, such limited reward schemes could be devised. A full property right is, inter alia, (1) presumptively good "against the world" and (2) enforceable by an injunction. Either of those characteristics could be removed in order to avoid violating the proviso. For example, there might be a "liability rule" option, giving a right that is not enforceable by injunction, or what I call a "stowaway" option, giving a right that is good only against those persons whose motives are parasitic.

Though in the real world these alternatives are unlikely to be practicable, they are worth discussing for two reasons. First, they help to illustrate further the nature of the claims involved, namely the public's liberty right in the common and the laborer's claim to deserve reward. Second, they may provide guidance for governmental agencies willing to try to gather the information necessary to implement these options. Since the "liability rule" and "stowaway" approaches give the laborer (who deserves a reward) something without impairing the public's right in the common, these approaches are morally superior to handling conflicts by denying the laborer all reward.

\section{Liability rule protections}

Awarding property rights does not usually preclude use of an owned resource, because ordinarily markets form and users pay for the benefit they seek. If allowing property rights in the goods at issue generates an increase in efficiency and thus boosts the gross societal output, it could be argued that the increase might be spread among members of society in such a way that people who need to use the owned resources can pay for them out of the "excess" output so generated. This possibility does not, however, ensure that granting a full property right will never violate the proviso. It is far from clear that all intellectual property rights add to society's total wealth. ${ }^{202}$ and it is even less clear that a particular user will individually reap enough of a benefit to pay for any rights to copy, particularly considering that the level of transaction costs in the intellectual product area can be quite high. ${ }^{203}$ But there may be some

202. A plausible argument can be made that intellectual property rights will indeed increase efficiency. The focus of such arguments tends to be the contention that, in the absence of property rights, there will be underproduction due to "free rider" problems. See, e.g., William M. Landes \& Richard A. Posner, An Economic Analysis of Copyright Law, 18 J. LEGAL STUD. 325 (1989); see also Gordon, Fair Use, supra note 11, at 1610-14. A plausible argument can be made on the other side as well, focusing on the "deadweight loss" imposed by monopolies. See Gordon, Merits of Copyright, supra note 10, at 1436-37 and sources cited therein. However difficult it is to resolve the controversy about the putative efficiency gains of intellectual property systems, it is harder still to make an argument that the gains generated by any increase in efficiency will be spread among those who might otherwise be negatively affected by the grant of rights.

203. See Gordon, Fair Use, supra note 11, at 1600. 
alternative to the market-perhaps a governmentally-created market substitute such as a "reasonable royalty" damage award, or a compulsory license ${ }^{204}$ - that could offer the laborer some reward while preserving for the public its liberty to use the common.

Conceivably subject matters not otherwise ownable might become partially ownable through this device. For example, although the proviso allows particular musical songs to be owned, it would prohibit the ownership of musical forms (such as the symphony, the fugue, or the concerto), on the ground that there would be no alternative musical form "enough and as good" in which composers could communicate in the relevant period. Thus, even if the invention of the symphonic form were attributable to a particular individual, he or she could have no ownership in it. But what if the invention of the symphonic form made all musicians one hundred dollars richer than they otherwise would have been? In this case, giving the inventor ownership of the symphonic form would leave a later composer with no ground for complaint under the proviso, so long as she could purchase the right to utilize the symphonic form she needed at a total $\operatorname{cost}^{205}$ of no more than one hundred dollars. The law could mandate that the price go no higher. ${ }^{206}$ When the amount the plaintiff creator charges for the use is no greater than the amount of money her product has put in the pocket of the defendant who is utilizing the work, then access is costless for the user. That is because the creator is essentially paying the access fee herself, by her "Pains" to which the other has "no right." ${ }^{207}$ In such cases, a creator might be entitled to assert a semi-

204. A "compulsory license" requires property owners to give a license to use the property to anyone who meets governmentally-set criteria, usually at governmentally-set rates of compensation. A compulsory license is a form of liability rule protection. See, e.g., the discussion of an innovative possible use of compulsory licensing in Jane C. Ginsburg, Creative and Commercial Value: Copyright Protection of Works of Information, 90 COLUM. L. REV. 1865, 1924-36 (1990).

Calabresi and Melamed's classic article distinguished among three kinds of protection for a plaintiff's entitlements, one of which was "liability rule" protection (i.e., noninjunctive, monetary remedies). Guido Calabresi \& A. Douglas Melamed, Property Rules, Liability Rules and Inalienability: One View of the Cathedral, 85 HaRv. L. REv. 1089 (1972). An example is the privilege of necessity in tort law: a defendant's activity protected by the privilege was not to be restrained, but he had to pay for any damage he did. See Vincent v. Lake Erie Trans. Co., 124 N.W. 221 (1910); see also Boomer v. Atlantic Cement Co., 257 N.E.2d 870 (1970) (cement plant allowed to keep emitting pollutants so long as it paid damages); Francis Bohlen, Incomplete Privilege to Inflict Intentional Invasions of Interests of Property and Personality, 39 HARV. L. REv. 307 (1926); Gordon, Fair Use, supra note 11, at 1622-1624 (liability rule alternatives to fair use).

Viewed retrospectively, a liability rule operates like a monetary remedy for violation of a right. Viewed prospectively, a liability rule might be viewed as granting potential defendants a compulsory license to use a creators' product.

205. If the user is not to be made worse off, the total of both purchase price and transaction costs borne by her would have to be equal to or less than the value she places on the purchased right.

206. This is a suggestion with practical difficulties, but much legislative precedent. Price controls were part of the Statute of Ann, the first intellectual property statute, and compulsory licenses (with fees set by a governmental agency) are part of today's intellectual property law-though they do not apply to most uses. See, e.g., 17 U.S.C. $\$ 111$ (1992).

207. LOCKE, supra note 24 , at 291 (bk. II, $\$ 34$ ). Recall that the labor theory accepts the proposition that one person has no right to another's pains (absent the kind of survival circumstance which would trigger a requirement of charity). The proviso does not contradict that position. It merely sets up priorities. 
property interest in the many subject matters that the proviso would otherwise require to be open to costless use.

The foregoing analysis thus suggests that perhaps a creator whose injunctive control over a work would violate the proviso would be entitled to a lesser degree of control, such as a right to a monetary benefit. The court could award a "damage only" remedy, ${ }^{208}$ or the legislature could create a compulsory license to give the creator this right, and set rates so that the user will not have to pay more for the intellectual product than the product brought him in revenues. When full property rights would violate the proviso, such a limitation of remedy might allow the creator some reward for her efforts.

Allowing the proviso to be satisfied in this way does not violate the "nonfungibility" criterion discussed earlier. While we have stipulated that there is no possible tradeoff which could compensate a later creator from being prohibited from commenting about his culture, money trades off against money quite easily. This mode of satisfying the proviso, however, is obviously not applicable when the intellectual product has given the potential user only nonmonetary benefits.

There are several implications of the foregoing discussion. First, this nonproperty mode of satisfying natural law is probably only available against commercial users, for they are the only ones likely to be able to draw a monetary return from their use. If the benefit a user stands to draw from the initial work is nonmonetizable, then no matter how sizeable the benefit, he might be unable to purchase a use right, or he might be able to purchase it only at the cost of impairing other nonfungible interests. Assertion of a property right against a non-commercial user could therefore do impermissible harm. Second, this approach is equivalent to giving creators rights against users for any net monetary benefits they reap from the work. That is, this approach does little more than produce a restitutionary right to payment for value added.

Third, under the suggested approach, courts or administrative agencies would have to determine and put a price on the user's level of transaction costs and benefits. It is difficult to determine the proportion of a defendant's income attributable to use of a plaintiff's intellectual product. In addition to problems of proof, the notion of "attributable to" may involve a normative judgment. Admittedly courts engage in that task now (in deciding, for example, how

Although a user has no right to benefit from a creator's pains, a creator has no right to impose certain kinds of pains on a user. When property enforcement would simultaneously recapture benefits and cause harms, the right against harms trumps the right of recapture, and enforcement of the laborer's property right is forbidden. Cf. Gordon, On Owning Information, supra note 10, at 180-221.

208. Courts are still resistant to the damage-only approach in the copyright context, but there is some sign that this may change in the future. See, James L. Oakes, Copyrights and Copyremedies: Unfair Use and Injunctions, 18 HOFSTRA L. REv. 983, 992-97 (1990) (suggesting that even in cases where violation of right is proved and gives rise to monetary relief, free speech principles might warrant denying injunctive relief). 
much of a movie's revenues are attributable to use of an infringing screenplay ${ }^{209}$ ), but the task is difficult and imprecise.

The legal system may be unwilling to adopt this approach because it may be expensive or even impracticable. Markets are less expensive to administer, more sensitive to varying preferences, and more conducive to incentives than are governmental substitutes. ${ }^{210} \mathrm{~A}$ system of intellectual property bereft of injunctive relief raises the prospect of a fully regulated pseudomarket, with all the familiar and intractable issues of centralized decisionmaking.

\section{Stowaways: Instead of a Trespass or Strict Liability Right, Owners Might be Given a Right Actionable Only upon Proof of Specific Intent by Defendants}

A second potential method exists for reconciling the public's claim in the common with the creative laborer's claim to deserve a reward. Even though a creator might not be able to bar a user with legitimate purposes linked to employment of the common, the creator should be able to bar a commercial user who has been drawn to the work solely in order to save himself fungible resources such as money, effort, and time. It arguably will not threaten the proviso to allow a creative laborer to assert a right of exclusion against such a commercial user, whom we will call a "stowaway" to distinguish him from more innocent free riders.

If a stowaway's purpose is solely to save effort or expense by taking advantage of another's investment of effort, and he has no interest in utilizing the intellectual product for its own sake, several things follow. Unlike the scholar or artist, this person's position has not been changed by the dissemination of the intellectual product in a way that requires use of the product to maintain his freedom to comment on his world. Nor is he someone for whom use of the product is essential to the use of his rational and creative faculties. Instead, this person is indifferent to the content of the product itself, and he wishes to copy it for reasons unrelated to its substance. Engaged in a deliberate effort to reap benefits, he can choose to refrain from involvement with the product if it will not be profitable. ${ }^{211}$

209. See, e.g., Sheldon v. Metro-Goldwyn Pictures Corp., 309 U.S. 390, 408 (1940) (upholding lower court's acceptance of expert testimony).

210. See Calabresi \& Melamed, supra note 204 (comparing property and liability rules in terms of accuracy and administrative cost). For further applications of this classic argument to the intellectual property setting, see Wendy J. Gordon, Asymmetric Market Failure and Prisoner's Dilemma in Intellectual Property, 17 U. DAYTON L. REv. 853, 853-59, 868-69 (1992); Gordon, On Owning Information, supra note 10, at 230-38 (arguing that intellectual property rights are more justifiable from economic point of view when they are likely to bring markets into being); cf., Gordon, Fair Use, supra note 11, at 1601 (arguing that courts are, and should be, more likely to refuse enforcement to intellectual property owner when defendant would have been unable to purchase contested use through market). text.

211. Compare the unexpected way images can "capture" artists, supra note 189 and accompanying 
In the case of a stowaway, motivated as described, we may be able largely to dispense with the restrictions on property rights otherwise necessitated by the proviso. Locke suggested at one point that his proviso was intended only to protect the stranger who had an honest desire to work the previouslyappropriated resource for himself, and not to protect the stowaway who "desired the benefit of another's Pains, which he had no right to, and not the Ground which God had given him in common with others to labour on. . .."212 Only the former had a right to complain or a potential right to use what the appropriator had produced. "God gave the world ... to the use of the Industrious and Rational ... not to the Fancy or Covetousness of the Quarrelsom and Contentious."213 It may, therefore, be unnecessary to investigate whether giving property would satisfy the proviso in those cases where a stranger's solely parasitic, stowaway motivations can be shown. ${ }^{214}$

A pull toward a "stowaway" expansion of a creator's exclusive rights would help to explain the results in certain anomalous copyright cases. In copyright, motive is legally irrelevant to the basic question of infringement; even unconscious copying triggers liability. ${ }^{215}$ Yet under the fair use rubric, the presence of a stowaway motive nevertheless seems to persuade courts to make actionable types of use that might otherwise be outside an author's control. For example, although facts are usually not subject to copyright ownership, ${ }^{216}$ in one case a reporting service was enjoined from summarizing factual material because it was engaged in "chiseling for personal profit."217 In the field of parody, courts have been more likely to find infringement where the defendant wishes only "to capitalize financially on the plaintiff's original work"218 or "to reap the advantages of a well-known tune and short-cut the rigors of composing original music."219 Such results are consistent with the

212. LoCKE, supra note 24 , at 291 (bk. II, $\$ 34$ ).

213. Id. at 291 (bk. II, § 34).

214. Locke intimates that satisfying the proviso is a way of testing for the presence of stowaway motives, see id. (one who complains when "as good" is left shows he merely wants "the benefit of another's Pains"); conceivably, therefore, satisfying the proviso may be unnecessary if these motives are directly shown.

215. See Gordon, Jurisprudence of Benefits, supra note 10, at 1028-32.

216. See Feist Publications, Inc. v. Rural Telephone Service Co., 111 S. Ct. 1282 (1991); cf. 17 U.S.C. $\$ 102($ b) (1988).

217. Wainwright Securities, Inc. v. Wall Street Transcript Corp., 558 F.2d 91, 96-97 (2d Cir. 1977), cert. denied, 434 U.S. 1014 (1978). This result may be impossible after Feist, which held that the white pages of phone books are uncopyrightable. $111 \mathrm{~S}$. Ct. at 1285 (1992). Feist, in effect, increased the amount of "creativity" that must be found in a treatment of facts before that treatment is entitled to any copyright protection.

218. Pillsbury Co. v. Milky Way Productions, Inc., 215 U.S.P.Q. (BNA) 124, 131 (N.D. Ga. 1981) (citation omitted) (distinguishing between such works and a work that is "in the nature of an editorial or social commentary"), cited in Fisher v. Dees, 794 F.2d 432, 437 (9th Cir. 1986).

219. Fisher v. Dees, 794 F.2d at 439 n.5. The Fisher court attributed this purpose to the defendants in MCA, Inc. v. Wilson, 677 F.2d 180 (2d Cir. 1981). In MCA, defendants copied the song "Boogie Woogie Bugle Boy of Company B" almost verbatim, and titled it "Cunnilingus Champion of Company C." In the eyes of the Fisher court, this song was enjoined because its motive was solely exploitative and it was thus "not a parody." Fisher, 794 F.2d at 439 n.5. 
Lockean approach, where such stowaway parodies would probably not be within the proviso's protection.

There are problems, however, with predicating any expansion of creators' rights on stowaway motives. First, the various doctrines of intellectual property law divide among themselves the many kinds of intangible products that might be ownable under a Lockean system. It would be improper to allow a "stowaway" finding to erode the boundaries among doctrines, as some of the cases just mentioned seem to have done. Second, an infringer will ordinarily have a mix of motives. Since the proviso gives a "trump" to motives of free expression, there may be relatively few persons who have a sufficiently singletrack motive to be classified as stowaways. Third, there are administrability problems whenever motives are part of a legal standard. States of mind are difficult to determine with accuracy. Fourth, even if it could be determined that a defendant is a stowaway, his motives are not the only ones that matter. The people who buy the defendant's work may have more complex motives, the pursuit of which may be sheltered by the proviso. For example, although a stowaway may have been unaffected by the dissemination of the intellectual product in question, and may be uninterested in addressing the substantive issues raised by the product's contents, those who buy from him may have been negatively affected by the initial dissemination and wish to buy the stowaway's copies in order to respond to the original work. If so, arguably the stowaway should be allowed to utilize the prior work as their agent.

\section{F. Congruence with Contemporary Legal Structures}

\section{General Parallels}

Many aspects of Locke's theory are congruent with the common law. Although this is not surprising, in that Locke drew on English common law as one of his sources, it does make use of the theory more plausible.

American common law has long awarded ownership to those who take possession of unclaimed physical resources, ${ }^{220}$ suggesting that judges have indeed found attractive the idea that people who appropriate unused and unclaimed resources have some claim of right to them. The "officious intermeddler" who labors in another's vineyard usually receives legal claim to neither property nor pay for his efforts, ${ }^{221}$ whereas she who labors in the

220. Possession plays a role in many states' law regarding the creation of private property in publicly owned land, minerals, and other natural resources. For a sketch of the possession principle, its applications and exceptions, see Richard A. Epstein, Possession as the Root of Title, 13 GA. L. REv. 1221 (1979); see also Alfred Yen, Restoring the Natural Law: Copyright as Labor and Possession, 51 OHio ST. L. REV. 517 (1990).

221. See, e.g., RESTATEMENT OF RESTITUTION $\$ 129.3 \mathrm{cmt}$. d, illus. 5 (where a trespasser knowingly takes shrubs not belonging to him and doubles their value through his gardening efforts, the plaintiff shrub owner is entitled to their value as improved, thus granting plaintiff the benefit of defendant's efforts). Even 
wild may often keep what she reaps. ${ }^{222}$ As for Locke's starting point-one's property in one's own body and one's own labor-I have elsewhere argued that tort law and restitution law are consistent not only with recognizing the uncontroversial right against being compelled to labor for others, but also with recognizing a laborer's right (in some circumstances) to have the government extract payment on her behalf from those who use her work. ${ }^{223}$

There is no exact equivalent to the proviso in the American law of possession. Someone who shoots a duck can keep it, even if she has deprived another hunter of dinner. But many legislative enactments work to keep the common from being depleted too much. Consider, for example, federal clean air and clean water legislation. ${ }^{224}$ Even duck hunters must be licensed, and may face a limit on the number of birds they can shoot down. More importantly, our tax and welfare systems can be viewed as an attempt to implement the proviso's protection for fungible common resources, eliminating private property where necessary to make sure the baseline well-being of the worst off is not harmed by the property-owning system in general.

The proviso also has important echoes in our common law and equity jurisprudence. One is the policy often implemented in restitution law to deny a benefactor compensation where to do so would cause harm to the beneficiary. ${ }^{225}$ In addition, a change of position induced by reliance gives rise to rights under a host of legal doctrines within contract law, tort law, and agency law, and the proviso gives some similar protection. ${ }^{226} \mathrm{~A}$ creator who leads others to use her work should not be entitled to withdraw arbitrarily permission for use, particularly if in doing so the creator leaves the audience worse off. If the public's view of itself or its world is changed by a creator, this change in position may, as reliance does, erode the foundation of Lockean property, namely, the "unquestioned" right of the laborer to his own efforts.

Similar parallels appear when one considers the rule in contemporary tort law that strangers have no duty to aid each other. That rule embraces a principle much like Locke's starting point: persons have no obligation to use

if the officious laborer is under the mistaken apprehension that the vineyard is his own, he may not recover. See ROBERT GoFf \& GARETH JONES, THE LAW OF RESTTIUTION 95-96 (1966).

222. In copyright, similarly, the music arranger is free to sell his version of a melody only if the original is in the public domain. If the melody is subject to another composer's copyright, an arranger who proceeds to write an arrangement without that composer's permission would violate that other creator's exclusive right to make derivative works. 17 U.S.C. $\$ 106$ (1992).

223. See generally Gordon, Of Harms and Benefits, supra note 10; see also Gordon, On Owning Information, supra note 10, at 166-221.

224. See, e.g., 42 U.S.C. $\$ 7401$ et seq. (1983) (air quality legislation); 33 U.S.C. $\S 1251$ et seq. (1986) (water quality).

225. See Gordon, On Owning Information, supra note 10, at 180-220; $c f$. Robert A. Long, Jr., Note, A Theory of Hypothetical Contract, 94 Yale L.J. 415, 427-32 (1984) (restitution should be ordered when there has been market failure, but only if after restitution payment individual defendant is in Pareto-superior position).

226. See, e.g., Paul T. Wangerin, Damages for Reliance Across the Spectrum of Law: Of Blind Men and Legal Elephants, 72 IowA L. REV. 47 (1986). 
their efforts to assist others. But there are exceptions to the "no duty to aid" rule, areas within which persons do have claims on others' efforts. Where there is a duty to aid, the person with the duty lacks the unencumbered entitlement to one's own labor that is Locke's starting point. Without that entitlement there can be no claim to a private property right. If Lockean theory operates in a manner which is consistent with the common law, it should grant property where the laborer would have no "duty to aid" under tort law, and it should deny property largely where the laborer would have a duty to aid under tort law. This is indeed the case.

The Second Restatement of Torts suggests that persons have duties to aid where, inter alia, they have done something that makes other people worse off than they otherwise would have been. ${ }^{22}$ If one person starts to rescue another and then abandons him, ${ }^{228}$ or if the first person has tortiously or innocently caused the other's injury, ${ }^{229}$ or if the first person has led the other to rely on him to his detriment, ${ }^{230}$ the first person is likely to be made liable to the second if he fails to give a reasonable degree of aid. In these cases, the first person has harmed the second; a person who causes harm does not have the ordinary entitlement to the fruits of his own labor.

The exceptions to the no-duty rule thus also suggest good analogical ground for the proviso. If harmed individuals have a right ${ }^{231}$ to the personal labor of those persons who harm them, as they do under tort law, then a fortiori they should have a privilege to use the harmful products of labor to protect themselves. ${ }^{232}$ The proviso provides them such a privilege.

Although the proviso is consistent with some aspects of positive law, one should not make too much of these parallels-particularly because differences exist as well. For example, there are cases where a claim for restitution can be successfully asserted despite harm to the defendant or reliance on his part. ${ }^{233}$ Further, most land is distributed today in a way that does not leave "enough, and as good"; even if one accepts the arguable fungibility of land for other economic benefits, it is far from clear that the worst off have received full

227. See RESTATEMENT (SECOND) OF TORTS $\$ \$ 321-23$ (1965).

228. Id. $\S 323 \mathrm{cmt}$. e; see, e.g., O'Neill v. Montefiore Hosp., 11 A.D.2d 132 (N.Y. 1960).

229. RESTATEMENT (SECOND) OF TORTS § 322 (1965); see, e.g., Maldonado v. Southern Pac. Transp. Co., 629 P.2d 1001 (Ariz. Ct. App. 1981). There are cases to the contrary, however, which suggest that only a wrongful causing of harm triggers a duty to aid. In fact, this was the traditional common law nule. See, e.g., Union Pacific Ry. v. Cappier, 72 P. 281 (Kan. 1903) (innocent injurer has no duty to aid victim).

230. See, e.g., Farwell v. Keaton, 240 N.W.2d 217 (Mich. 1976).

231. A "duty to aid" necessarily implies someone has a correlative "right to be aided." See the discussion of Hohfeld, supra note 46.

232. Thus, the common law imposes some duties to share one's possessions with strangers, see Ploof v. Putnam, 71 A. 188 (Vt. 1908) (necessity imposes duty on dock-owner to permit boater to dock during storm), and does so more readily than it imposes duties to aid.

233. See DAN B. DOBBS, HANDBOOK ON THE LAW OF REMEDIES $§ 11.9$ (1973) (noting limitations on courts' recognition of expenditure as change of position); see also 3 GEORGE E. PALMER, THE LAW OF RESTITUTION § 16.8(e) (1978) (discussing mistake and change of position via expenditures by defendant). 
compensation in our current system. The proviso as a normative principle must stand or fall on its own merits.

\section{Congruence with Contemporary Intellectual Property Law}

An examination of the full contours of a Lockean intellectual property system is outside our scope. ${ }^{234}$ It is useful nonetheless to focus on a key issue in contemporary legal doctrine: whether general ideas can be owned. In contemporary copyright and patent law, Congress and the courts have determined that there can be no ownership in abstract ideas. ${ }^{235}$ The nonownership of general and abstract ideas is perhaps the foremost protection current law provides for First Amendment interests. A Lockean analysis reaches results consistent with this pattern. ${ }^{236}$

The proviso prohibits a creator from owning abstract ideas because such ownership harms later creators. The more general an idea is, the more capable it would be of rediscovery by others. To give ownership in such fundamentals would deprive future creators of a meaningful opportunity otherwise open to them. ${ }^{237}$ For instance, if ownership in the idea of art were given to the first person to put pigment on surface, the remaining common would be remarkably small, and it is hard to imagine anything "as good" that could be left for others to discover. Further, even if a particular abstract idea would not be quickly rediscovered, such ideas are so fundamental to the rational faculty that allowing ownership in them would violate the equality of creative liberty which the proviso also embodies.

In addition, to give ownership in general ideas would have a restrictive impact on the amount of the physical world open to later comers. For example, it took someone's imagination to recognize that plants could be husbanded. If the first person to put a grain of corn in the ground were given ownership of the idea of agriculture, all the farmland might soon fall under his heirs' dominion. Just as Locke believed that justice did not justify property where an appropriator of physical things threatened to engross all land, justice would not justify property where a creator or inventor threatened the same result.

It might be supposed that one way to satisfy the proviso while still giving ownership in ideas would be to restrict owners' exclusive rights to control

234. For such an exploration, see generally Gordon, Shape of Intellectual Property Rights, supra note 108.

235. See, e.g., 17 U.S.C. $\$ 102(b)$ (1988) (copyright); Nichols v. Universal Pictures Corp., 45 F.2d 119, 121 (2d Cir. 1930), cert. denied, 282 U.S. 902 (1931) (copyright); Wright Aeronautical Corp. v. General Motors Corp., 166 F.2d 636 (7th Cir. 1948) (patent).

236. On the common law side, state courts will sometimes give protection to the creators of ideas, but only if those ideas are "novel" and "concrete" and there is some kind of "legal relationship between the parties . . ." MElville B. NimMER \& DAVID NiMMER, NimMER ON COPYRIGHT $\$ 16.01$ (1992).

237. See Nozick, supra note 72 , at $181-82$ (likelihood of rediscovery providing a limit on the duration of property rights). 
copying, and give owners no rights against persons who independently happen to recreate or rediscover the idea. ${ }^{238}$ For example, agriculture was undoubtedly invented countless times by scattered tribes. Allowing independent rediscovery would thus keep the first farmer from having a monopoly over everyone's horticultural efforts.

Lockean property rights are limited to protecting an initial laborer from someone injuriously taking advantage of "another's Pains", which an independent rediscoverer does not do. Lockean law would, therefore, indeed permit independent rediscoverers to use their creations and discoveries, thereby lessening the danger that idea-ownership would violate the proviso. But the dangers would not be eliminated. Once put into the cultural stream by an initial creative person, intellectual products may be impossible for others not to use. Consider someone trying independently to invent a paper clip after having seen one. Some inventions "infect" one immediately with knowledge of their workings. Since one often does not know in advance what one is about to learn irretrievably by participating in daily life in our media-saturated culture, learning from others will be unavoidable in circumstances where independent creation would also have been possible, and giving the first inventor a right to prohibit all copying of his creation could close off some of the best opportunities otherwise open to others.

In addition to the proviso, ownership of abstract ideas is also prohibited by Locke's theory of labor. As was argued earlier, if labor is to give rise to property it must involve some purposive and substantial stake on the part of the creative person. ${ }^{239}$ Let us apply that notion to an early artist, perhaps the first person who scratched pictures of mammoths on a cave wall. Has he created the idea of art? If so, should he own it? On the one hand, this first artist's behavior is intentional and purposive, and he has added something of value to the world. Further, although he is using only a small portion of the artistic domain, Locke does not insist that the appropriator employ all the appropriated property all the time, provided that the unused property does not "spoil" and perish. ${ }^{240}$ On the other hand, it is highly doubtful that the artist conceptualized "the creation of art" as his purpose. Even if he did conceive of such a goal, he does not have sufficient interest or stake in the "all" of art for him to be taken as having appropriated it. A single artist is no more capable of occupying the whole area of art than a single farmer is capable of occupying the whole earth. Art itself would therefore not be a "fitting

238. Unlike patent and trademark law, which can prohibit the use of independently created, identical products, copyright law prohibits only those acts which involve some copying of the copyright proprietor's work. 17 U.S.C. $\$ 106$ (1992).

239. See discussion supra notes $79-85$ and accompanying text.

240. LOCKE, supra note 24 , at $299-300$ (bk. II, § 46). 
reward"241 in such a case, while ownership of a particular picture might be. For these reasons, the nature of labor alone (even without reference to the proviso) would prohibit the ownership of the broad idea of art.

Both Locke's approach to labor and his proviso are consistent with, and potentially explanatory of, one of the principal doctrines within current intellectual property law that preserves free speech interests and the public domain. This may increase our confidence in using Lockean theory to resolve more disputed cases.

\section{APPLICATIONS}

This Part will apply the foregoing discussion to several recent intellectual property controversies implicating free speech issues. In virtually all of these cases, the Lockean approach would have given the defendants at least a partial victory. The first fact pattern, the "Gay Olympics" case, involved a trademark dispute. The second area of controversy concerns a group of copyright cases where biographers quoted from the writings of their subjects, and the subjects then sued to enjoin the books' publication. The third controversy involves the West Publication Company's injunction against LEXIS's effort to provide its subscribers with jump cites to West-published judicial opinions. The case arose under federal copyright, but today would probably be adjudicated under the state intellectual property doctrines of unfair competition or misappropriation. The fourth and fifth examples involve parodies. Two were litigated under copyright law, the other under copyright and a form of trademark law known as "anti-dilution" protection.

\section{A. The "Gay Olympics" Case}

In 1981, a Bay-area medical professional began an organization to sponsor a major sports competition "designed to combat homophobia and to work for the health and tolerance of gay and lesbian persons."242 The competition was to be named the "Gay Olympic Games." The group apparently hoped the "Olympic" name would stress the mainstream nature of its members' accomplishments and thus help combat antigay prejudice. ${ }^{243}$ San Francisco Art \& Athletics (SFAA) expected to encounter no opposition to its plans to call their competition the "Gay Olympics."244 The term "Olympic" had been

241. See BECKER, PROPERTY RIGHTS, supra note 67, at 52-53 (describing criteria for "fitting" a reward to labor).

242. Petition for Rehearing at 2, quoted in International Olympic Committee v. San Francisco Arts \& Athletics, 789 F.2d 1319, 1320 (9th Cir. 1986) (Kozinski, J., dissenting from a denial of rehearing en banc).

243. See 789 F.2d at 1321 .

244. International Olympic Committee v. San Francisco Arts \& Athletics, 219 U.S.P.Q. (BNA) 982 , 983 (N.D. Cal. 1982) (granting preliminary injunction), aff'd, 781 F.2d 733 (9th Cir. 1986), aff'd sub nom. 
used by hundreds of organizations and businesses, ${ }^{245}$ including such disparate groups as the "Special Olympics," the "International Police Olympics," and even the "Canine Olympics," without apparent objection from the U.S. Olympic Committee (USOC). ${ }^{246}$ But the U.S. Olympic Committee brought suit against the sponsors of the Gay Olympics.

The USOC owns a federally-registered trademark interest in the word "Olympic."247 But for several reasons, the Committee would have found it difficult to win under trademark law. First, to prevail in a trademark suit the plaintiff ordinarily has to show that the challenged use is likely to confuse the public. ${ }^{248}$ This would be hard to prove: the public would be unlikely to think the "Gay Olympics" were part of the standard Olympic festival. The "Special Olympics" does not seem to produce this sort of confusion.

Second, to obtain trademark protection for a descriptive term, the putative trademark owner must prove that the public associates the term with the product's producer. This association is referred to as "secondary meaning."249 Since the word "Olympic" appears to be a descriptive term for a type of athletic event, traditional trademark law would require the USOC to prove secondary meaning and, given varying public uses of the word, such proof might be difficult to find. Further, even if enough secondary meaning was shown to maintain the Committee's trademark interest, trademark law contains a "fair use" defense that allows organizations to use trademarked descriptive terms in their descriptive senses. ${ }^{250}$

Third, the word "Olympic" might be considered generic. Under trademark law, words that describe product types cannot be used as trademarks. Even marks that have been developed at great cost will, if the public comes to use

San Francisco Arts \& Athletics, Inc. v. United States Olympic Comm., 483 U.S. 522 (1987).

245. In the Los Angeles telephone directory alone, there were over 140 businesses or organizations using the word "Olympic" in their names at the time of the litigation. International Olympic Comm. v. San Francisco Arts \& Athletics, 789 F. 2d 1319, 1323 n.4 (9th Cir. 1986) (Kozinski, J., dissenting from denial of rehearing en banc).

246. Id. at 1323. The USOC apparently continues to approve of these and many other uses of the term "Olympic." The extent and nature of the USOC's activity in this regard, however, is unclear. The Supreme Court observed that the USOC had initiated many trademark proceedings against others prior to suing SFAA. 483 U.S. at 542 n.22. The Ninth Circuit majority opinion, however, suggested that the timing might have been otherwise. It noted that "USOC denies discrimination and adduces other litigation by it, albeit begun after SFAA made a claim of discrimination in the instant case." International Olympic Comm. v. San Francisco Arts \& Athletics, 781 F. 2d at 736 (affirming injunction against SFAA) (emphasis added).

247. San Francisco Arts \& Athletics, 483 U.S. at 530.

248. Id. at $522,531$.

249. "Trademark protection for descriptive marks is extended only in recognition of consumer acceptance and recognition of such marks as denoting only one seller or source. That is, trademark protection is extended only where the user has proven secondary meaning in a descriptive mark." $J$. ThOMAS MCCARTHY, 1 TRADEMARKS AND UNFAIR COMPETTTION, $\$ 11: 09$, at 361 (1992) (citation omitted). There is no need for the public to know the name of the producer; the association can be to an anonymous source.

250. Id. \$ 11:17. See WCVB-TV v. Boston Athletic Ass'n, 926 F.2d 42, 46 (1st Cir. 1991) (television station entitled to use the words "Boston Marathon" even though not licensed by the Boston Athletic Association, as a fair use; but see id. at 44 , noting that station was not "running its own marathon on Patriots Day, which a viewer might confuse with the BAA's famous Boston Marathon"). 
them generically, fall into the public domain. Everyday nouns such as "aspirin," "thermos," "brassiere" and "escalator" all began as manufacturers" imaginative trademarks for particular products, and were protected as such until the public began to use the terms to indicate not the products of a particular producer, but rather products of a particular type. ${ }^{251}$ The courts then declared them "generic," and opened them for use by all. ${ }^{252}$ When the courts have to choose between depriving the trademark owners of some of the "fruits of their labor," on the one hand, or depriving the public and competing manufacturers of the ability to communicate simply and accurately on the other, ${ }^{253}$ the courts opt to sacrifice the creators' reward in favor of securing the public's liberty of communication. Thus, if the word "Olympic" is a generic communicative term, it would not be protectable as a trademark. . $^{254}$

Not surprisingly, the U.S. Olympic Committee prevailed on a different theory. Instead of trademark law, the USOC turned to the Amateur Sports Act of $1978,{ }^{255}$ a special federal statute which appears to give the USOC broad exclusive rights in the word "Olympic." The Court concluded that the Amateur Sports Act gave the USOC rights in the word "Olympic" which obtained regardless of the existence of consumer confusion and which were immune from the usual trademark defenses. ${ }^{256}$

In response, defendant SFAA argued for a contrary interpretation of the relevant statute $e^{257}$ and also challenged the statute on two constitutional grounds: the Fifth Amendment's equal protection component-because of the possibility that the Committee's decision to enjoin "Gay Olympics" was based on discrimination against homosexuals ${ }^{258}$ - and the First Amendment. ${ }^{259}$ In the Supreme Court the SFAA argued that trademark law's consumer-confusion test for infringement, and trademark law's genericness doctrine, were required by the First Amendment. ${ }^{260}$

251. Id. $\$ 12: 03$, at $12-37$ to $12-40$.

252. See generally id. $\S 12$, at $12-3$ to $12-7,12-11$ to $12-40$, and $12-51$ to $12-60$. There are some exceptions which apply in situations in which part of the public uses the term generically and part uses the word to indicate a particular producer. For example, the word "aspirin" can be used by any producer, despite the fact that the term was coined by Bayer, since the general public treats the word "aspirin" as synonymous with salicylic acid. At the time of the aspirin litigation, however, "aspirin" connoted Bayer as the source to druggists; therefore Bayer was entitled to require competing aspirin makers to use the chemical name (salicylic acid) and not the word "aspirin" when selling to druggists. See id. \$ 12:16.

253. This communication has a competitive aspect, and it is this aspect to which courts pay the most attention. To allow one manufacturer to monopolize a generic name would give him an undeserved advantage in the marketplace. For example, persons asking for "aspirin" might not care about the brand, and might not mean to communicate any restrictions in the request. If Bayer owned the term, however, only Bayer aspirin would be forthcoming in response to the request.

254. It would require expensive consumer surveys to determine this. MCCARTHY, supra note 249, $\S 12: 2$, at 410 .

255. 36 U.S.C. $\$ 380$ (1989).

256. San Francisco Arts \& Athletics, 483 U.S. at 531-35.

257. Id. at 528 .

258. Id. at 542 .

259. Id. at 531-32.

260. Id. 
The Supreme Court read the Amateur Sports Act as the USOC had hoped it would: it held that the USOC possessed a right in the word "Olympic" not subject to the consumer-confusion requirement and independent of federal trademark defenses. ${ }^{261}$ The Court then, over the strong dissent of Justice Brennan, ${ }^{262}$ rejected all of the defendant's constitutional contentions. Regarding the Equal Protection claim, the Court found insufficient state action to trigger inquiry under the Fifth Amendment. ${ }^{263}$ As for the First Amendment challenge to allowing the Olympic Committee to enjoin nonconfusing uses of the word "Olympic," the Court ruled that Congress had not violated the Amendment in making this broad grant to the USOC. Crucial here was the Court's assertion that the power granted to the Committee "restricts only the manner in which the SFAA may convey its message" and does not restrict that message itself. ${ }^{264}$

The Court also rejected the claim that the Constitution mandates applying the genericness doctrine to protect the public use of the word "Olympic". The Court admitted that "the suppression of particular words 'run[s] a substantial risk of suppressing ideas in the process," ${ }^{265}$ but asserted that this principle must be "balanced" against a quasi-natural-rights claim to deserve ownership. The Court treated the First Amendment as the weaker interest: ${ }^{266}$ "[W]hen

261. Id. at 530 .

262. Id. at 548. Justice Brennan's dissent argued that the case involved state action, both because he considered the USOC a government actor, id. at 549-56, and because of symbiosis between government and the USOC. Id. at 556-60. He would have upheld the defendant's first amendment claim as well. Id. at 561-73.

Justice Marshall joined in Justice Brennan's dissent. Justices O'Connor and Blackmun dissented in part. They agreed with the majority on the First Amendment issues, but joined Justice Brennan's dissent on the Fifth Amendment claim, arguing that the case should have been remanded "for determination of petitioners' claim of discriminatory enforcement." Id. at 548.

263. Id. at 542-47.

264. Id. at 536 (emphasis added). The Court also argued that any restriction on expressive speech is "incidental to the primary congressional purpose," applies to less-protected commercial speech, and "is not broader than necessary to protect the legitimate congressional interest." Id. at 540 .

265. Id. at 532 (quoting Cohen v. Califomia, 403 U.S. 15, 26 (1971)) (upholding liberty to wear a jacket emblazoned "Fuck the draft").

266. Oddly, after delivering itself of these views the Court indicated that there was "no need in this case to decide whether Congress ever could grant a private entity exclusive use of a generic word." 483 U.S. at 532. The Court then went on to opine that Congress could reasonably have concluded that the word "Olympic" was not generic. However the Court's supposed factual analysis does imply that genericness doctrine is not constitutionally required.

The Court gave as its primary reason for ratifying the supposed nongenericness of "Olympic" the possibility that "the commercial and promotional value of the word "Olympic" was the product of the USOC's "own talents and energy ...'" 483 U.S. at 533. But nothing in the history of the genericness doctrine allows such considerations to keep a word that the public understands generically from falling into the public domain. See generally MCCARTHY, supra note 249 , at ch. 12 . By utilizing a formulation in which genericness is defeated by a showing of investor-created commercial value, the Court arguably held (by implication) that the core of the genericness doctrine is not constitutionally required.

Furthermore, as Justice Brennan noted, "even after a trademark has acquired secondary meaning, it may be used in a good-faith descriptive manner under the Lanham [federal trademark] Act." 483 U.S. 548, 565 n.26 (Brennan, J., dissenting) (citation omitted). By refusing to consider this trademark defense, the Court essentially ruled that descriptive and accurate use of language could be prohibited under a property rationale. 
a word acquires value 'as the result of organization and the expenditure of labor, skill, and money' by an entity, that entity constitutionally may obtain a limited property right in the word.".267

A more careful application of natural-rights property theory would yield far different results in this case. To see this we must isolate the nature of the "laborer's" claim as well as the claim of the public. We will then consider how the Lockean theory would address conflicts that might arise between these claims.

As was discussed above, ${ }^{268}$ the Lockean laborer begins her claim to deserve property by mixing some of her labor with the common. The USOC (and its predecessor and affiliate organizations ${ }^{269}$ ) utilized several components from the common, such as the word "Olympic," the heritage of the Olympic games, the division of the world into nation states, a set of already defined sport activities, and the custom of holding amateur athletic events. It employed discretion and judgment in mixing these components into a distinctive pattern. Just as copyright law recognizes that one can exercise significant creativity in combining pre-existing elements, ${ }^{270}$ the labor of creating a new mixture out of existing concepts is worthy of respect. In addition, nineteenth-century Olympic organizers (USOC's predecessors in interest) added elements of their own, such as the passing of the torch, that increased the pageantry and thus the value of the event. ${ }^{271}$

To be worthy of protection in the Lockean system, such labor must be purposive and yield a result beneficial to the laborer or to others. ${ }^{272}$ With respect to purpose, the Committee seeks, in part, to hold the Games in order to further international amity. ${ }^{273}$ It also seeks to obtain funding in order to

267. Id. at 532 (quoting International News Service v. Associated Press, 248 U.S. 215, 239 (1918) [hereinafter INS v. AP]). On this and similar misuses of the INS v. AP case, see Gordon, On Owning Information, supra note 10 , at 266-273.

The Court's discussion provides a good example of the fact that Courts take the First Amendment less seriously when "property" interests are involved. The same tendency can be seen in the Ninth Circuit opinion. 781 F. 2d 733, 737 (9th Cir. 1986). As Judge Kozinski noted in his dissent from denial of hearing en banc, "To say that the word Olympic is property begs the question. What appellants challenge is the power of Congress to privatize the word ...." 789 F.2d 1319, 1321 (9th Cir. 1986) (Kozinski, J., dissenting from denial of rehearing en banc).

268. See supra Part II(B)(I).

269. See San Francisco Arts \& Athletics, 483 U.S. 534 at n.11 (discussing USOC predecessor organizations).

270. See 17 U.S.C. $\$ 103$ (1988) (compilations are copyrightable); see also 17 U.S.C. $\$ 101$ (1988) (definition of "compilation" as "a work formed by the collection and assembling of preexisting materials ... that are selected, coordinated or arranged in such a way that the resulting work as a whole constitutes and original vork of authorship.") A compiler's copyright extends only to her arrangement and selection; if the individual components were in the public domain when she began, or owned by others, they so remain. The compiler gains no "exclusive right in the preexisting material," 17 U.S.C. $\$ 103$ (b) (1988), but only rights against those who copy her way of selecting ordering and coordinating the material.

271. San Francisco Arts \& Athletics, 483 U.S. at 540 n.18.

272. See supra Part II(B)(1).

273. San Francisco Arts \& Athletics, 483 U.S. at 533 n.10. 
ensure that the Games continue. ${ }^{274}$ As a means of pursuing the latter goal, the USOC apparently licenses the word "Olympic" and associated symbols, such as the five interlocking Olympic rings. ${ }^{275}$ The beneficial result the USOC produces is somewhat more difficult to locate, for the "commercial magnetism"276 or "promotional value" of the Olympic mark on which the Court focused is unlikely to count as a beneficial product under Lockean labor principles. ${ }^{277}$ But the Games themselves are a beneficial result, and within the range of the purposes sought. The USOC therefore has at least two kinds of "stakes" in maintaining its Games, and a stake in maintaining the commercial value of the word "Olympic" as a means of achieving the Games' survival. Under the Lockean and deontological principles outlined earlier, ${ }^{279}$ unjustified interference that would impair either of these stakes is prohibited by natural law.

That would not end the inquiry, of course. The USOC is entitled to some security, but the public is as well. The next task is to determine the public's claim under natural law. As was stipulated earlier, the public is entitled to an unimpaired public domain, and to an ability to describe its surroundings and context as freely as its predecessors could have done. ${ }^{230}$ Part of this entitlement is a freedom to make accurate use of language. What the SFAA wished to do seems to fall within this range: it wanted a name to convey that its games were serious amateur athletic events in the tradition of the classical Greek and modern Olympic Games. SFAA's purposes seem to include much more than the desire to take "the benefit of another's Pains"281 which we already know is an insufficient justification for causing the laborer harm. ${ }^{282}$ Even if that was part of its purpose, it was also pursuing a justifiable purpose, which was to use current language to describe its aspirations. Given the

274. See id. at 537-39.

275. Id. at 526 n.4.

276. The Court asserted, "it is clear that the SFAA sought to exploit the 'commercial magnetism' . . of the word given value by the USOC." 483 U.S. at 539.

277. Promotional value, good will, popularity, and similar elements of value are joint products of both the public and the creator to a greater extent than are intellectual products themselves. True, even standard intellectual products - collocations of words, music, scenes-will be beneficial only if someone appreciates them; labor is never the only source of value, even for Locke. But with standard intellectual products the active role of the producer and the comparatively passive role of the public makes it easier to assign the resulting value primarily to the laborer. By contrast, with products such as popularity and "commercial magnetism," the chain of causality and responsibility is much harder to trace. Thus the Court is on unsteady ground in using such promotional value to uphold the statute. Usually a trademark is not purposely created for its own sake; the "benefit" purposely created is the good will of the owning entity (such as its reputation for manufacturing high-quality products), which the trademark merely happens to represent.

278. See supra Part II(B)(1).

279. Id.

280. See supra Part II(C)(1) \& (2).

281. LOCKE, supra note 24, at 291 (bk. II, \$ 34).

282. See supra Part II(B)(1) (arguing that deontological principles forbid a person-at least if she lacks special claims of need-from using another person's resources to serve her own ends). 
uniqueness of the term "Olympic," the SFAA had access to no other term "as good" with which to employ its "Industry." 283 Since that term stemmed originally from a public domain source (the original games at Olympia), it is part of the common to which earlier peoples, and thus the SFAA as well, ${ }^{284}$ should have access. As was made clear by the discussion of the "stowaway option,, 285 the public is entitled to copy in pursuit of mixed motives.

Will there be a conflict between the SFAA's prima facie natural-rights claim to an unimpaired common and the USOC's prima facie natural-rights claim to be free of interference? If the USOC is given the right to prohibit SFAA's use of the word "Olympic," it would clearly interfere with SFAA's rights to use the common. As Circuit Judge Kozinski noted, "By giving the [U.S. Olympic Committee] exclusive possession of the word ['Olympic'], Congress has diminished the rights of everyone else, withdrawing from the public domain a term used by many and useful to more."286 It is less clear whether giving the SFAA the liberty to use the word would interfere with the USOC's Lockean product. The record is bare of evidence that the SFAA's use of the word "Olympic" would have caused harm to the USOC's plans. ${ }^{287}$ The various opinions in the case contain little more than the bare assertion "that the SFAA sought to exploit the "'commercial magnetism'... of the word given value by the USOC" 288 and that "this could undercut the USOC's efforts to use, and sell the right to use, the word in the future . . ."289 If there is no interference, then there is no conflict and the SFAA's use of the word should be permitted.

The result is no different if, for the purposes of argument, we take it as given that the use of "Gay Olympic Games" would interfere with the USOC's stakes in its Games and its mark. If this were the case, the initial laborer's and the public's prima facie claims would conflict. For reasons discussed in Part II(D) above, when the two claims conflict, property does not form under the Lockean proviso.

It will be useful to map the proviso onto the Gay Olympics case and contemporary law. Our focus here will be an issue considered by the Gay Olympics Court: whether all trademark law is required to include the

283. LOCKE, supra note 24 , at 291 (bk. II, § 34).

284. By principles of intergenerational equity, what was available to predecessors must be available now if (1) the item is nonfungible or, if fungible, (2) no compensation is available. See supra Part II(C)(1) \& 2 and Part II(D).

285. See supra Part II(E)(2).

286. International Olympic Comm. v. San Francisco Arts \& Athletics, 789 F.2d 1319, 1320 \& 1323 (9th Cir. 1986) (Kozinski, J., dissenting from denial of rehearing en banc).

287. San Francisco Arts \& Athletics v. United States Olympic Comm., 483 U.S. 522, 572-73 (Brennan, J., dissenting) ("T] here is no proof in the record . . . that the SFAA has harmed the USOC's image by its speech."). See also International Olympic Comm. v. San Francisco Arts \& Athletics, $789 \mathrm{~F}$. 2d 1320 (9th Cir. 1986) at 1325 (not "the slightest showing that the enjoined use would harm anyone") (Kozinski, J., dissenting from a denial of rehearing en banc).

288. 483 U.S. at 539 (citation omitted).

289. Id. (emphasis added). 
genericness doctrine and the related rule that descriptive uses even of valid trademarks are "fair uses" and should be permitted. Both of these legal doctrines protect the public's freedom to make accurate use of language. Under the proviso the genericness doctrine and the descriptive-use defense are necessary prerequisites for grants of trademark rights. ${ }^{290}$

When the Gay Olympics Court rejected the proposed application of the genericness doctrine ${ }^{291}$ and gave the USOC an injunction, this did not merely make the common less valuable. The Amateur Sports Act as enforced by the Supreme Court actually depletes the size of the common and leaves nothing "as good" behind. The Court's majority opinion approves of taking a word out of the common, i.e., out of the public domain, and assigning it to one party so exclusively that it cannot even be used for accurate and descriptive communication. Ordinary trademark rights do not have this effect; even when a trademark right is granted in pre-existing words, such a right usually can be asserted against potentially confusing and deceptive usages only. ${ }^{292}$ Under the Amateur Sports Act, however, even descriptive communication can be forbidden.

The Supreme Court tried to defuse objections by pointing out how much the Olympic Committee had contributed to the current meaning of the term "Olympic." 293 For example, the Court noted that the custom of carrying the torch from city to city "was an innovation of the modern Olympic Committee." 294 But even if the Committee was responsible for the re-entry of the word "Olympic" into contemporary language, the word and its accompanying events changed the environment it entered. Like the introduction of Arabic numerals discussed earlier, the new word displaces old usages and creates a new reality for which it becomes the best descriptor. It cannot be "owned," therefore, without violating both concerns-equality and

290. Similarly, allowing suit against "nonconfusing" uses raises the possibility of restraining accurate communication. These various doctrines overlap: if someone other than the trademark owner uses a trademarked word in its descriptive or generic sense, the public is not confused. Ironically, then, the genericness doctrine is particularly important in a regime, like the one the Court enforces under the Amateur Sports Act, where suit can be brought against nonconfusing usages.

291. The Court suggested that it need not reach the issue of whether the genericness doctrine was constitutionally required-that its views of the genericness doctrine were dicta-since (the Court argued) the word "Olympic" was not generic. 483 U.S. at 532 . As was also pointed out above, however, see supra note 266, there are significant problems with the Court's application of the genericness doctrine, and the fair implication of the opinion seems to be that the Court rejected the notion that the genericness doctrine is constitutionally required.

292. See Stephen L. Carter, The Trouble with Trademark, 99 YALE L.J. 759 (1990). Less wellestablished state theories of trademark protection also give trademark owners rights against nonconfusing uses if such uses would "dilute" the value or impact of the mark. Similar reasoning has sometimes crept into federal decisions construing the federal trademark act (the Lanham Act) as well. Such an approach can be dangerous to free speech if not accompanied by strong defenses such as a privilege for descriptive usages.

293. San Francisco Arts \& Athletics, 483 U.S. at 533-34.

294. Id. at 540. 
harm-found in the proviso. ${ }^{295}$ This is something the genericness doctrine recognizes, and under natural law as well the USOC would have been required to respect the public's communicative rights.

Sometimes particular words are essential. In Locke's language, there is nothing "as good." When this is true, blocking nondeceptive use of the words violates the proviso because it interferes with the public's ability to communicate. ${ }^{296}$ The Court was being disingenuous in saying that despite the injunction the SFAA's message can still be delivered, and that only its "manner" is being restricted. To quote Judge Kozinski:

To say that the SFAA could have named its event "The Best and Most Accomplished Amateur Gay Athletes Competition" no more answers the first amendment concerns here than to suggest that Paul Robert Cohen could have worn a jacket saying "I Strongly Resent the Draft."297

Words have potential for "making and changing the world."298 It is just this potential that the SFAA sought to draw upon in using the term "Olympic" to describe its event. Under the Lockean approach therefore the defendant's First Amendment claims would have found receptive ground and the injunction the USOC sought would have been denied.

The only remaining issue is whether the Olympic Committee might be entitled to a monetary recovery. If the SFAA made more money from its festival because of the USOC's promotional efforts, then a natural-rights approach could appropriately require the SFAA to pay the USOC a fee up to this amount. If proof of monetary benefit was not forthcoming, the SFAA should be entitled to costless use.

295. Equality is violated because people were better able to describe their world accurately before the ownership than after it. Standing alone, this is sufficient to trigger the proviso and defeat the USOC's asserted property right of exclusion. The intergenerational or "vertical" lack of equity is compounded if the USOC was discriminating against the SFAA because of its gay-rights political mission; a "horizontal" inequity in the use of language would thus also exist.

The harm prong is violated because of the harm to the public's descriptive ability, and the loss of an item from the public domain. This, too, would be sufficient standing alone to trigger the proviso and defeat the USOC's asserted property right of exclusion.

296. "By prohibiting use of the word 'Olympic,' the USOC substantially infringed upon the SFAA's right to communicate ideas." 483 U.S. at 569-70 (Brennan, J., dissenting).

297. San Francisco Arts \& Athletics, 789 F.2d at 1321.

298. 483 U.S. at 570 n.33 (Brennan, J., dissenting) (quoting JAMES BOYD WHITE, WHEN WORDS LOSE THEIR MEANING 11 (1984)). 


\section{B. Suits Against the Biographers of L. Ron Hubbard, J.D. Salinger, and Richard Wright}

Suits have been brought against biographers who quoted from the letters, diaries, and other writings of famous authors J.D. Salinger, ${ }^{299}$ L. Ron Hubbard, ${ }^{300}$ and Richard Wright. ${ }^{301} \mathrm{~A}$ biographer who needs to present his subject's words as evidence has little choice but to copy expression, yet at least one treatise-writer opines that "[n]o court has ever held that the public has a right to know expression." ${ }^{302}$ The question is whether the natural-rights approach would come to a different result.

Under copyright law, copying a substantial amount of expression is prima facie copyright infringement. ${ }^{303}$ But such copying can be forgiven under the fair use doctrine, ${ }^{304}$ a privilege whose application depends on, among other things, the nature of the defendant's use and the impact the copying would have on the plaintiff's market. ${ }^{305}$ In several of the biography cases, one doctrinal factor weighed particularly strongly in the plaintiffs' favor: some of the material quoted was from unpublished works such as letters or diaries, and fair use has historically been assumed to be less available for unpublished works. ${ }^{306}$ Although until recently precedent on this latter question was scant, and the statute does not explicitly mention the unpublished nature of copied works as a factor for consideration, the Supreme Court did place significant weight on a work's unpublished status in a 1985 case. There the Supreme Court held fair use treatment was unavailable to The Nation magazine when it printed a story quoting from President Ford's about-to-be-published memoirs. ${ }^{307}$ Particularly after the Nation case was decided, courts gave the owners of copyrights in unpublished works particularly vigorous copyright

299. Salinger v. Random House, Inc., 650 F. Supp. 413 (S.D.N.Y. 1986) (denying preliminary injunction), rev'd, 811 F.2d 90 (2d Cir.), cert. denied, 484 U.S. 890 (1987).

300. New Era Publications Int'l, ApS v. Carol Publishing Group, 729 F. Supp. 992 (S.D.N.Y. 1990) (enjoining publication of biography), aff'd in part and rev'd in part, 904 F.2d 152 (2d Cir.) (injunction reversed; fair use found), stay denied, 497 U.S. 1054 (1990), cert. denied, 111 S. Ct. 297 (1990); New Era Publications Int'l, ApS v. Henry Holt \& Co., 695 F. Supp. 1493, 1527-28 (S.D.N.Y. 1988) (injunction refused on First Amendment grounds), aff'd on other grounds, 873 F.2d 576 (2d Cir.) (denial of injunction affirmed, but solely on ground of laches), cert. denied, 110 S. Ct. 1168 (1990).

301. See Wright v. Warner Books, Inc., 748 F. Supp. 105 (S.D.N.Y. 1990), aff'd, 953 F.2d 731 (2d Cir. 1991) (biographer of Richard Wright permitted to include some quotations from published and unpublished work).

302. PATRY, supra note 15 , at 466 (citations omitted).

303. Id. at 154-59.

304. The doctrine of fair use was first accorded statutory recognition in the 1976 Copyright Act, 17 U.S.C. § 107. See generally Gordon, Fair Use, supra note 11.

305. The statutory factors are nonexclusive. "[S]ince the doctrine is an equitable rule of reason, no generally applicable definition is possible, and each case raising the question must be decided on its own facts." H.R. REP. No. 1476, 94th Cong., 2d Sess. 65 (1976), reprinted in 1976 U.S.C.C.A.N. 5659, 5679 [hereinafter cited as HOUSE REPORT].

306. See, e.g., S. REP. No. 473, 94th Cong., 1st Sess. 62, 64 (1975) ("The applicability of the fair use doctrine to unpublished works is narrowly limited ....").

307. Harper \& Row Publishers v. Nation Enterprises, 471 U.S. 539 (1985). 
protection. ${ }^{308}$ Another factor, however, appeared to weigh strongly in the defendants' favor: the biographies were works of scholarship and criticism, both of which are mentioned explicitly in the preface to the fair use statute. ${ }^{309}$ The House Report accompanying the enactment of the current fair use statute even gave as an example of fair use "quotation of short passages in a scholarly or technical work, for illustration or clarification of the author's observations." 310 This example appears to embrace the biographers' usage.

Under the Lockean approach, writers who produce works of authorship by mixing their labor and talent with language and ideas from the common are engaging in labor worthy of protection. Against purely commercial copyists, they would have no trouble obtaining both monetary relief and injunctions. But here the defendants claimed to be quoting in order to provide a more accurate description of their world-they were using their subjects' words as facts. ${ }^{311}$ Facts are ordinarily part of the common. Therefore a conflict seems to exist between the laborer's claims and the public's, the latter represented by the biographers. To examine how Lockean theory would resolve the conflict, the proviso will be applied to the two factors mentioned above: the scholarly nature of the defendants' writings, and the unpublished nature of the plaintiffs' writings.

As a general principle, the favored status that fair use doctrine gives to works of scholarship and criticism is consistent with the proviso. If copying from an existing work is necessary for a defendant to show its intellectual effects, then without the privilege of copying the defendant is worse off in regard to her use of the intangible common than if she had not been exposed to the work initially. In the case of influential figures such as Salinger, Hubbard, and Wright, such a test seems easy to meet, particularly if the biographers have been heavily influenced by the persons they are quoting.

The proviso's protection even applies to a biographer who has made a living teaching contemporary American fiction to college students. Although he might well be better off financially in a world where works by Salinger and Wright exist even if he is forbidden to quote from them, he is not better off with respect to his ability to describe his world accurately and communicate to his readers the nature of art as he understands it. ${ }^{312}$ In regard to those

308. See, e.g., Salinger v. Random House, Inc., 811 F.2d 90 (2d Cir.), reh'g denied, 818 F.2d 252, cert. denied, 484 U.S. 890 (1987).

309. 17 U.S.C. $\$ 107$ (1992) ("for purposes such as criticism, . . scholarship, or research").

310. HOUSE REPORT, supra note 305 , at 5679-80. (Among the examples listed are "quotation of excerpts in a review or criticism for purposes of illustration or comment; quotation of short passages in a scholarly or technical work, for illustration or clarification of the author's observations.").

311. See Leval, Memorial Lecture, supra note 16, at 171-72 ("at times it is the subject's very words that are the facts"). See also his opinion in New Era Publications Int'l v. Henry Holt \& Co., 695 F. Supp. 1493, 1503 (S.D.N.Y. 1988), aff'd on other grounds, 873 F.2d 576 (2d Cir. 1989); Leval, Fair Use Standard, supra note 16, at 1113 (discussing "need for quotation as a tool of accurate historical method"); Gordon, Reality as Artifact, supra note 142, at 96-100.

312. If a biographer quotes more than necessary for such a purpose, such use falls outside the 
abilities, which are not fungible, he is less well off than a person who had never known and been influenced by these authors' works. Such a person might be ignorant of what Wright and Salinger have to teach, but she would be able to deal with the influences she did encounter with full freedom. For contemporary biographers to be made less well off in this way by an assertion of property rights would violate the proviso.

Such cases are even stronger when viewed from the perspective of persons who feel they have been negatively influenced by works of authorship. For example, one of Hubbard's biographers was a person who had joined the Church of Scientology at nineteen. ${ }^{313}$ From the angry words he used to describe Hubbard, one can infer that he perceived the experience and perhaps Hubbard's work negatively. ${ }^{314}$ The "harm" prong of the proviso protects those who wish to a utilize a work in an effort to free themselves from its influence. ${ }^{315}$

As mentioned, some of these cases involved quotation from unpublished works. It was long assumed as to published and unpublished works that the "fair use" privilege was more readily granted for the former, but less readily for the latter. ${ }^{316}$ As a general matter, this rule seems consistent with the results the Lockean theory would yield, for unpublished works are unlikely to reach people to influence them in a way that requires them to use quotations to effect rebuttal. ${ }^{317}$

The restricted ambit of fair use, however, has found expression recently in several cases where the authors of the unpublished works at issue were figures of public importance, one political (President Gerald Ford ${ }^{318}$ ) and several cultural (Salinger, Wright, and Hubbard). Once these individuals acted in ways that significantly affected the world, use of their words to understand them can fall within the shelter of the proviso. ${ }^{319}$ This admittedly goes

proviso's shelter.

313. New Era Publications Int'l, ApS v. Carol Publishing Group, 729 F. Supp. 992 (S.D.N.Y. 1990) (enjoining publication of biography), aff'd in part and rev'd in part, 904 F.2d 152 (2d Cir.) (injunction reversed; fair use found), stay denied, 497 U.S. 1054 (1990), cert. denied, 111 S. Ct. 297 (1990).

314. New Era, 904 F.2d at 154.

315. See supra Part II(D)(5). When a defendant's work uses several quotes, some of which are protected by the proviso and some of which are not, the Lockean analysis would probably not justify giving an injunction against the whole. The protected uses are not merely noninfringing; they are part of a defendant's property right - his entitlement to an unimpaired common, which enforcement of the plaintiff's right would infringe. Current law tends to take the opposite position, enjoining defendants' works in which only some quotations are "unfair", see, e.g., New Era v. Holt, 873 U.S. F.2d at 584, as if only one party's property (the author's) was capable of being infringed.

316. See PATRY, supra note 15 , at $436-48$.

317. The designation "unpublished" has no per se Lockean significance. Obviousiy the defendants in the cases had access to the technically unpublished works, or they could not have quoted from them. If the works had a powerful impact on these individuals, they would have had some shelter under the proviso to quote, at least assuming their initial access was not against the will of the author. Whether the argument would be different for purloined letters I do not reach.

318. See Harper \& Row Publishers v. Nation Enters., 471 U.S. 539, 549-55 (1985).

319. Similarly, many commentators have argued that there should be a sort of "public figure" rule in copyright, comparable to the special treatment given discussion of public figures in defamation cases. The 
beyond the effect of a creator's property-owning activity and evaluates the net harm of a set of his actions. But that is a fair extension of Locke's proviso. ${ }^{320}$ Courts should be wary of overestimating the importance of a work's unpublished status when the author's behavior has made the topic of that work a matter of public importance. Congress seems to have come to a similar conclusion, for it has enacted an amendment to undo the over-deference to the unpublished status of a work. ${ }^{321}$ The biographers of Salinger, Hubbard, and Wright should be able to quote from unpublished works to the extent necessary to present an accurate picture of persons who have influenced the public.

The Salinger court seems to have been concerned that the biographer was utilizing Salinger's letters to "enliven his prose," viz. "taking advantage of another's Pains." To the extent this is true, a duly apportioned monetary award would be appropriate. The biography, at any rate, should not have been enjoined.

\section{West Publishing Company v. Mead Data Central, Inc.}

By the middle of the 1980's both Mead Data's LEXIS and West Publishing's WESTLAW were on-line, with each legal research service providing its computer subscribers the full text of judicial opinions and indicating the official citations where those opinions could be found on library shelves. ${ }^{322}$ But at that time neither was equipped to provide "star pagination" to the interior of judicial opinions. Without star paging, subscribers would only know where the first page of an opinion could be located, but not where intermediate portions of text appeared ${ }^{323}$ Since most courts require citation

Supreme Court in the Nation case rejected these suggestions. Nation Enterprises, 471 U.S. at 555-60. It may be that because of the particular facts of the latter case, enforcement did not violate the proviso. In the Nation case, the defendant published very shortly before the magazine excerpt was to appear in Time, a publication authorized by plaintiff. The Court noted:

[R]espondents [do not] assert any actual necessity for circumventing the copyright scheme with respect to the types of works and users at issue here. Where an author and publisher have invested extensive resources in creating an original work and are poised to release it to the public, no legitimate aim is served by pre-empting the right of first publication.

Id. at 557 (citation omitted).

320. Cf. Rosemont Enters. v. Random House, Inc., 366 F.2d 303, 307 (2d Cir. 1966), cert. denied, 385 U.S. 1009 (1967) (fair use found in suit against biography of Hughes which quoted from articles in which corporation friendly to Hughes held the copyright). Even though Hughes had not written the articles that were the subject of the suit, and even if the articles had not negatively affected the public, Hughes himself had changed the public's world sufficiently that access to information concerning him was considered necessary to the public interest.

321. See 17 U.S.C. $\$ 107$ (Supp. 1992). (A new sentence was added to the end of $\$ 107$, which reads: "The fact that a work is unpublished shall not itself bar a finding of fair use if such finding is made upon consideration of all the above factors.").

322. See L. Ray Patterson \& Craig Joyce, Monopolizing the Law: The Scope of Copyright Protection for Law Reports and Statutory Compilations, 36 U.C.L.A. L. REv. 719, 721 n.3 (1989).

323. West Publishing Co. v. Mead Data Central, Inc., 799 F. 2d 1219, at 1222 (8th Cir. 1986), cert. denied, 479 U.S. 1070 (1987). 
to printed reporters, researchers in search of page cites for quotes provided by their on-line services needed access to the physical volumes. ${ }^{324}$

Mead Data's LEXIS service was the first to develop the technical capacity to provide star pagination. ${ }^{325}$ But among the various official and unofficial reporters to which it would provide citations, many were reporters published by West, Mead Data's on-line competitor, such as F. Supp., F.2d, and regional reporters for state decisions. ${ }^{326}$

When Mead Data announced the availability of the new service, West responded by bringing suit, alleging that LEXIS star pagination would infringe the copyrights West held in its printed reporters. ${ }^{327}$ Mead Data claimed, among other things, that West brought the suit to buy some time in order to catch up. ${ }^{328}$

Under copyright law West indisputably possessed certain valid copyright interests in its reporters, with regard, for example, to the headnotes and case summaries prepared by West's employees. ${ }^{329}$ But LEXIS did not copy these items; it copied only the page numbers. West argued that its arrangement of cases was a copyrightable compilation, and that LEXIS infringed the arrangement by providing page numbers keyed to it. ${ }^{330}$

At the time of the suit, the copyrightability of compilations and directories of even minimal creativity was fairly well established. ${ }^{331}$ Even white page telephone directories had been deemed the subject of valid copyrights, infringed by directories prepared with the white pages' aid that were arranged differently. ${ }^{332}$ This line of precedent, however, was at odds with the 1976 Copyright Act, which required that compilations be "selected, coordinated, or arranged in such a way that the resulting work as a whole constitutes an original work of authorship" ${ }^{333}$ as a prerequisite to protection. Not long after the West case was decided, the Supreme Court overruled the phone book cases and reaffirmed that directories' arrangements could not be protected unless they were "authored" with some judgment and creativity. ${ }^{334}$ At the time of the West suit, however, the plaintiff had a fairly strong argument that its arrangement of cases-however uncreative and obvious those principles of arrangement might have been-was sufficient to sustain a copyright.

324. Id.

325. Patterson \& Joyce, supra note 322 , at 721 n.3, 722 n.6.

326. West Publishing, 799 F.2d at 1222.

327. West Publishing Co. v. Mead Data Central, Inc., 616 F. Supp. 1571 (D.C. Minn. 1985) (granting preliminary injunction), aff'd, 799 F.2d 1219 (8th Cir. 1986), cert. denied, 479 U.S. 1070 (1987).

328. West Publishing, 799 F.2d at 1230 (opinion of Oliver, J., concurring in part and dissenting in part).

329. 799 F.2d at 1224.

330. Id. at 1222

331. Id. at 1223-24.

332. See Leon v. Pacific Tel. \& Tel. Co., 91 F. 2d 484 (9th Cir. 1937).

333. 17 U.S.C. § $10 \mathrm{I}$ (1988).

334. Feist Publications v. Rural Phone Serv. Co., 111 S.Ct. 1282 (1991). 
What was surprising about the plaintiff's case was its allegation that its copyright in the arrangement would be infringed by Mead Data's plan to copy West's page numbers. Defendant Mead Data argued, inter alia, that West was impermissibly seeking to protect a copyright in the page numbers themselves. ${ }^{335}$ Mead Data also contended that the arrangement itself was not copyrightable, and that even if it was, the LEXIS computer data array did not copy the arrangement. Mead Data also claimed that in some jurisdictions West was an "official" reporter of judicial decisions, and stressed the public policy-arguably inherent in copyright's fair use doctrine-that the public's access to law was a social interest justifying any copying of page numbers.

The Eighth Circuit upheld the lower court's grant of a preliminary injunction against the improvement in LEXIS service. The Eighth Circuit opinion reads more like a plenary treatment of the merits than a mere affirmance of a preliminary ruling, and in it the circuit court rejected virtually all of the defendant's contentions. It ruled that West's alleged status as an official reporter was not determinative, ${ }^{336}$ upheld the copyrightability of West's compilation, ${ }^{337}$ and ruled that star pagination would infringe the copyright. ${ }^{338}$ Allowing jump cites "would give users of LEXIS a large part of what West has spent so much labor and industry in compiling," 339 the court wrote, thus allegedly reducing the need to purchase West reporters.

After West Publishing was decided (and, presumably, settled with a large license-fee payment by Mead Data to West), ${ }^{340}$ the Supreme Court ruled that a significant degree of creativity is required before a compilation can sustain a copyright in its overall arrangement. ${ }^{341}$ West's trivial organizational efforts-dividing decisions by the level of court, geographic area, and broad subject areas such as bankruptcy or federal rules decisions ${ }^{342}$-would be highly unlikely to qualify under the new standards. If such a controversy arose today the plaintiff would probably place its hope not in federal copyright but in the state tort of misappropriation.

Misappropriation is a vague prohibition against "reaping where one has not sown" ${ }^{\prime 343}$ and is disapproved by many states because of its vagueness. But in recent years, along with other propertarian trends, misappropriation has grown in acceptability and power. I have written about the doctrine at length

335. West Publishing, 799 F. 2d at 1223.

336. Id. at 1226.

337. Id. at 1223-26.

338. Id. at 1227 .

339. Id.

340. Patterson \& Joyce, supra note 322 , at 722 \& n.6 (speculating about content of confidential settlement).

341. Feist Publications v. Rural Phone Serv. Co., 111 S.Ct. 1282 (1991).

342. West Publishing, 799 F.2d at 1226.

343. See International News Serv. v. Associated Press, 248 U.S. 215 (1918) (INS enjoined from copying news from AP bulletin boards and papers). 
elsewhere; ${ }^{344}$ let me note here merely that West could bring a plausible misappropriation action. ${ }^{345}$ Despite the likely change in most case reporters' copyright status, therefore, the controversy over star pagination remains ${ }^{346}$ and could potentially lead to future cases between parties other than West and Mead Data.

Turning to the Lockean analysis, the first issue is the nature of the laborer's claim. Unlike the copyright statute (which is constitutionally limited to protecting "works of authorship"), ${ }^{347}$ the Lockean approach does not demand that labor be creative or imaginative. The labor need only be purposeful and achieve some beneficial result. ${ }^{348}$ Therefore, the act of picking apples and laying them in a neat pile, or industriously collecting cases and publishing them in book form, is labor subject to protection under natural law.

There are, however, two significant difficulties with West's prima facie natural rights claim to property. First, the laborer's claim to exclusion rights depends on her having an entitlement to use her labor as she wills. ${ }^{349}$ As we saw in discussing the "duty to aid" parallel from tort law, ${ }^{350}$ when the laborer has a duty to use her efforts to assist someone, she will not have a right to prohibit that other person from using the labor-and thus she will not have the ordinarily available exclusion right. In other words, to have a naturalrights claim to reward, the laborer must produce something in excess of what she is obligated to produce for those who benefit. ${ }^{351}$

To the extent that West claims to be an "official" reporter for both the federal judiciary ${ }^{352}$ and some states, ${ }^{353}$ its compilations of case opinions may not be in excess of what it already owes to the public. ${ }^{354}$ If so, it has

344. See Gordon, On Owning Information, supra note 10.

345. Id. at 273-77 (discussion of the West Publishing case in the context of misappropriation law).

346. There already appear to be several "live" controversies over the ownership of legal codes and other compilations of law. See Patterson \& Joyce, supra note 322, at 724-28 \& n.16.

347. See Feist Publications v. Rural Phone Serv. Co., 111 S. Ct. 1282 (1991).

348. See supra Part II(B)(1).

349. See id.

350. See supra Part (II)(E)(1).

351. See BECKER, PROPERTY Rights, supra note 67, at 41-42. Thus, if a person paints a portrait on commission, he cannot demand extra "natural right" payment from the patron. His proper payment is what he agreed to. Note, however, that unlike Becker I argue that the laborer can be entitled to a reward from anyone to whom the duty was not owed. If third parties begin making posters and postcard versions of the portrait, the artist can potentially assert his natural rights claims against them; since he owed those third parties nothing to begin with, any benefit they receive from him is in excess of any duty he owed them.

352. West Publishing Co. v. Mead Data Central, Inc., 799 F.2d 1219, 1234 n.13 (8th Cir. 1986) (opinion of Oliver, J., concurring in part and dissenting in part) (noting a prior published claim by West). 353. See West Publishing, 799 F.2d at 1226 (noting that state designating a West-published reporter as its "official reporter" is not equivalent to West itself being employed by state; but accepting arguendo Mead's claim that West is "official reporter"). But see West Publishing Co. v. Mead Data Central, Inc., 616 F. Supp. 1571, at 1577 (D. Minn. 1985), aff"d, 799 F.2d 1219 (8th Cir. 1986) ("West is not the official reporter for any court in this country.").

354. In addition, West may already have received all the reward that was "due"-payment (in terms of books bought) from the very legal community that also wants to use LEXIS. Further, some of that reward West obtained may have been premised upon West's status as the provider of citations that most 
no claim of ownership against the public or against Mead as a member of the public. (As an alternative formulation of this argument: if West has any claim to reward from the public, it is a reward it already receives.) The lower court found that West was not required to publish opinions, ${ }^{355}$ but even if true that should not have been determinative. Though a requirement of publication may not have been explicitly placed on West by the statutes or court rules, West undoubtedly wanted such status and would undoubtedly have lost it if the company had ceased to publish accurate copies of judges' public-domain opinions for practitioners. Therefore, West may have lacked that freedom from duty that is the labor theory's starting point.

A second problem with West's prima facie claim to ownership is that the page numbers may not have been within the range of West's purpose. It is highly doubtful any West employee focuses his attention on page placement. When West's attorneys filed copyright registrations on its case reporter volumes, West did not even mention the page numbers as one of the elements in which copyright was claimed. ${ }^{356}$ Thus under the Lockean view of labor, the page numbers might not have even been considered a purposive part of what West labored to produce.

On either of these grounds, it would be appropriate to deny West a right of action against Mead Data. However, for the sake of discussion, let us assume that West had no duties to the public and that either the page numbers were deliberately chosen, or that copying the page numbers would interfere with other efforts in which West has a cognizable stake. Assuming, then, a prima facie laborer's claim, we turn to analyzing the nature of the public's claim under the natural-rights approach. ${ }^{357}$

The Supreme Court unanimously held, early in its history, that judicial opinions could not be protected by copyright. ${ }^{358}$ As the proviso would predict, "The Court could allow no impediment to the fullest possible dissemination of its judgments." 359 With the public-domain status of judicial opinions established, access to those opinions is part of the common to which the public is entitled. As the district court recognized in West, without a usable

lawyers need. There may be a kind of estoppel against West in profiting from its being a "standard" and then using this status as a "standard" to obtain monopoly advantages against competitors.

355. West Publishing, 616 F. Supp. at 1577. Compare the circuit court opinion at 799 F.2d 1226, which disbelieved the claim of West's official status, but stated that the official status of West did not matter because West "used sufficient talent and industry ... to entitle it to copyright protection under the 1976 Act as construed by ... recent cases." Id. The latter view-that an employee's "talent and industry" might trump his duty to his employer-is inconsistent with the natural-rights approach, which depends on the laborer's having an unencumbered initial right to her own efforts.

356. $799 \mathrm{F.2d}$ at 1233 (opinion of Oliver, J., concurring in part and dissenting in part).

357. The nature of the public's claim has been well stated on public policy grounds by others whose approach significantly overlaps with Lockean analysis. See generally Patterson \& Joyce, supra note 322. 358. Wheaton v. Peters, 33 U.S. (8 Pet.) 591, 668 (1834).

359. Craig Joyce, The Rise of the Supreme Court Reporter: An Institutional Perspective on Marshall Court Ascendance, 83 MiCH. L. REv. 1291, 1390 (1985), quoted in 799 F.2d 1240 (opinion of Oliver, J., concurring in part and dissenting in part). 
system of case citation, a judicial opinion's "voice is silent, and its teachings are unheeded"360 — an opinion "as issued, cannot be accessed." form of citation must be in the public domain if the law's public-domain status is to be meaningful.

A conflict does therefore appear to exist between West's claim to exclusivity in its page numbers and the public's claim to have free access to the law in the common. The proviso resolves the conflict in favor of the public.

As lawyers begin to rely upon computerized legal research devices that have abilities paper books do not, the previous citation sources become less valuable. ${ }^{362}$ For the common to remain as valuable, these new research devices need access to the preexisting citation formats. In many jurisdictions court rules require lawyers to provide citations from particular reporters. Unlike the stowaway, therefore, LEXIS and its subscribers are not merely seeking to take advantage of West's "Pains." Mead was not trying to save the effort of producing page numbers-in fact, Mead's LEXIS service provides its own numbering for all case opinions.

Giving ownership in intellectual products that have come to serve as standards, such as West citations or generic trademarks, would not ordinarily leave "enough, and as good."363 There may be room in the world for only one of a given type of thing, or a long-lived artifice may become a mode of communication. It is the nature of a standard that nothing "as good" is available. For these reasons, the proviso would be violated if the courts gave those who create standards in nonfungible goods a right to prevent people from utilizing them. ${ }^{364}$

Under the proviso, West would not have been entitled to obtain a competitive advantage ${ }^{365}$ from the fact that its page numbers had become

360. West Publishing, 616 F. Supp. at 1578.

361. Id.

362. I argue that the public's natural law claims are affected even if the common becomes less valuable for reasons not traceable to the original laborer; this issue need not be reached here, however, for West itself was one of the providers of on-line services.

363. See the treatment of the generic in the Gay Olympic case, supra Part III(A). Court citations are "standards" in this way.

364. Current law is uncertain in its treatment of standards. Some doctrines are sensitive to the need to preserve public freedom to use such communicative devices. When there is only one word to describe a product, for example, that word is declared "generic" and cannot be owned as a trademark. Similarly, a standard golf handicapping formula has been held to be open to public commercial use. United States Golf Ass'n v. St. Andrews Systems, Data-Max, Inc., 749 F.2d 1028 (3d Cir. 1984) (holding it permissible to use golf association's formula, without obtaining its consent, in a computer program enabling golfers to determine their own handicaps). On the other hand, the creator of the Dow Jones Average was able to enjoin the Chicago Board of Trade from marketing a futures contract whose index price would have been tied to the Dow. Board of Trade v. Dow Jones \& Co., 456 N.E.2d 84, 90-91 (Ill. 1983).

365. LEXIS time is expensive enough, and LEXIS text is inexact enough, that it is highly doubtful that LEXIS could completely substitute for an ordinary law library. Nevertheless, the court concluded that LEXIS star pagination would “adversely affect West's market position." West Publishing Co., 799 F.2d at 1228. By implication then, the court may have based its decision on a finding that West had obtained some market advantage by its sole control of the standard page numbers. 
standards sometimes required by courts and often used by lawyers to communicate with each other. Had West not existed, some other "official" mode of quoting case decisions would have evolved. The Eighth Circuit argues that because "the LEXIS star pagination feature would adversely affect West's market position,"366 "knowledge of the location of opinions within West's arrangement is a large part of the reason one would purchase West's volumes." 367 But that reason correlates directly with making effective use of the common; purchases so motivated are not within the range of outcomes for which West can fairly claim a reward.

In sum, according to natural law principles, the Court of Appeals for the Eighth Circuit was wrong to hold that LEXIS's planned reference to West's page numbers would violate West's copyright, and a misappropriation court would be wrong to give a plaintiff victory in future such cases. Under the proviso, West would not have been entitled to an injunction (though it might have received a monetary award if Mead had benefited from West's efforts at mere collection, which seems unlikely). Although some standards may involve fungible interests, case decisions and citations that judges require in order to decide the law are not fungible. ${ }^{368}$ As there is nothing "as good," they cannot be owned.

\section{Walt Disney v. Air Pirates and the "Pretty Woman" Case}

There are two kinds of parody: one where the owned work is predominantly a vehicle for a parody of other aspects of culture or society, ${ }^{369}$ and another where the owned work is itself the object of the parody. The former is only ambiguously sheltered by the proviso. Thus, when a comedian writes a ditty like "When Sonny Sniffs Glue" (parodying "When Sunny Gets Blue"), ${ }^{370}$ or Mad Magazine publishes a lyric entitled "Louella Schwartz Describes Her Malady" (parodying "A Pretty Girl is Like a Melody")," it seems as if any song might do as a vehicle. The parodist's purpose is simply

366. West Publishing Co., 799 F.2d at 1228.

367. Id.

368. According to the proviso, there are two primary issues in the ownership of standards: first, which of the many existing standards implicate interests in which there is a nonfungible entitlement, and second, of those that implicate only fungible interests, to what extent would allowing ownership of that standard increase the welfare of those who lose privileges of free use sufficiently that they are better off, in the long run, in a world where such ownership is permitted.

369. In any parody, some parody of "life and society" is inescapable; it "is almost an inherent aspect of any parody." Walt Disney Prods. v. Air Pirates, 581 F.2d 751, 758 n.15 (1978). The distinction here is rather between parodies which have among their aims the purpose of changing audience perception of the original work, and parodies which merely use the predecessor work to achieve some other purpose, including a purpose as simple as that of making people laugh.

370. Fisher v. Dees, 794 F.2d 432, 434 (9th Cir. 1986).

371. Berlin v. E.C. Publications, Inc., 329 F.2d 541, 543 (2d Cir.), cert. denied, 379 U.S. 822 (1964). Note that while in Fisher, 794 F.2d at 434, the defendant used some of the plaintiff's music as well as lyrics, Mad Magazine only utilized the lyrics-in terms of meter and some word choices-for its parodies. It directed the reader to sing its versions of the lyrics "to the tune of" the famous songs. 
to take some familiar song, any song, and create humor by showing the unexpected changes that can be rung upon its meter and rhyme scheme. Here the parodist could not rest on any need to respond to a change in cultural circumstances induced by the song. Nor could the parodist easily make a claim based on equality with first creators. On the one hand, the art form of parody would have been unavailable to someone who lacked predecessors. On the other hand, there probably always have been people who mocked the dominant culture and persons in authority. As some of those symbols of dominance were replaced over time with "owned" artifacts, the size of the common open to iconoclasts become smaller. For an iconoclast who wants to make the point that received culture is mutable, perhaps only allowing the freedom to make these "vehicle" parodies will preserve "enough and as good." But the point is a difficult one. Further complicating the analysis is the possibility that many parodies will be outside of the original creator's purposes and may not impair her "stake." If so, a pure Lockean property right would not extend to forbidding the parody. ${ }^{372}$

By contrast, the second type of parody-where the parodied work itself is the object-is a form of criticism and reaction to a work that has itself made an impact on its audience. Such parody achieves less ambiguous results under the proviso. An example is the controversy between Walt Disney Productions and the Air Pirates, a group of "counter-cultural" cartoonists. The background to the case warrants a bit of explication.

In the sixties, many middle-class college students rejected what they saw as their parents' attempts to pass on to them an antiseptic, Pollyanna view of the world; the students tried to substitute for it a more realistic sense of how things were. Many viewed the "Mickey Mouse world of scrubbed faces, bright smiles and happy endings" 373 as emblematic of the illusions whose power had to be dispelled if the students were to see accurately the pain and pleasure in the world. From this reconceived perception of pain, it was imagined, would come a new imperative toward social action; from the reconceived perception of pleasure would come a new tolerance for sexuality. The cartoonists known as the Air Pirates were part of this movement to reconceive the world, and "Walt Disney-the General Motors of the cartoon world, immense,

372. See supra Part II(B)(1). However, Lockean analysis would not forbid the positive law from giving creators more extensive rights than Locke's theory itself would generate, so long as the other affected parties were not harmed thereby. Therefore, should the author protesting an unauthorized parody be asserting a positive right more extensive than her original stake would justify under natural law, the propriety of that extended right might need to be judged, inter alia, by an economic analysis of whether the right served the public good. For an economic analysis of satires and parodies, see Gordon, Fair Use, supra note 11, at 1632-35. Note that under an economic analysis, special latitude should be given to parodists who, like Mark Russell, may lack time to seek permissions because of the topical nature of their art. See id. at 1628 (spontaneous decisions to use copyrighted works are more likely to warrant fair use treatment).

373. Kevin W. Wheelwright, Note, Parody, Copyrights and the First Amendment, 10 U.S.F. L. REV. 564, 571 (1976). 
inescapable, admirable, despicable"374 had a leading role among the guardians of the old perceptions.

The Air Pirates could have expressed their unease with Disney by writing a treatise explaining that the suburban idylls of Mickey Mouse and his friends omitted much of reality. But such a treatise would have been incapable of loosening the Disney characters' hold on the public's imagination. The only way to dim the aura of legitimacy adhering to the Disney world view would be to reach Mickey's audience emotionally, and this is the course the Air Pirates took. They drew a new sort of Mickey. Mickey and Minnie had sex with each other; Mickey and Daisy Duck had sex with each other; and Goofy was shown lifting his leg like a normal dog.

Under the proviso, the Air Pirates comics would have been privileged as a mode of rebutting the influence of Disney's work. As one observer commented: "Prodigious success and its responsibilities and failures draws parody. That's how a culture defends itself. Especially from institutions so large that they lose track of where they stop and the world begins so that they try to exercise their internal model of control on outside activities." ${ }^{.375}$

This is one of the areas, however, where the "fair use" doctrine as currently applied gives a set of freedoms less extensive than would the proviso. The Court of Appeals for the Ninth Circuit held that the Air Pirates infringed Walt Disney's copyright, rejecting the defense of fair use. ${ }^{376}$ Though subsequently the Ninth Circuit made its approach to parody somewhat more generous, ${ }^{377}$ it has not repudiated the result in the Air Pirates case itself. The proviso, by contrast, would shelter from injunction virtually any parody of this kind. Even those motivated solely by a desire to "capitalize financially on the plaintiff's original work" ${ }^{378}$ would be sheltered from injunction if they served an audience struggling to deal with the original work. Of course, a hefty monetary award might be owed.

The Lockean approach to parody requires inquiry into questions of motive. That this is a difficult issue was demonstrated recently by the opinions in the "Pretty Woman" case. ${ }^{379}$ There, the rap group 2 Live Crew had released a comic and derisive version of the pop standard "Oh, Pretty Woman," written by Roy Orbison and William Dees, without the copyright holder's permission. ${ }^{380}$ The three opinions in the case assess the purpose of the

374. Stewart Brand, Dan O'Neill Defies U.S. Supreme Court: A Really Truly Silly Moment in American Law, 21 Coevolution Q. 41 (1979).

375. Id. at 41 (emphasis added).

376. Walt Disney Prods. v. Air Pirates, 581 F. 2d 751 (9th Cir. 1978), cert. denied, 439 U.S. 1132 (1979).

377. See, e.g., Fisher v. Dees, 794 F.2d 432 (9th Cir. 1986).

378. Pillsbury Co. v. Milky Way Prods., 215 U.S.P.Q. (BNA) 124, 131 (N.D. Ga. 1981).

379. Acuff-Rose Music, Inc., v. Campbell, 754 F. Supp. 1150, 1155 (M.D. Tenn. 1991) (claim of copyright infringement dismissed on summary judgment), rev'd, 972 F.2d 1429 (1992), cert. granted, 61 U.S.L.W. 2116 (Mar. 30, 1993).

380. See Acuff-Rose Music, 754 F. Supp. at 1155. 
parody somewhat differently, ${ }^{381}$ with the circuit court majority simultaneously "accept[ing] the district court's conclusion that the purpose of the use was to parody the original, ${ }^{, 382}$ arguing with that conclusion, ${ }^{383}$ and re-characterizing it. ${ }^{384}$ But recognizing the difficulty of inquiry into motives and purposes does not by itself recommend jettisoning the Lockean analysis as impractical. As the "Pretty Woman" opinions themselves demonstrate-perhaps unintentionally-it may be necessary to grapple with questions of purpose ${ }^{385}$ to do justice to the issues at stake.

As the "Pretty Woman" parody seems to stand midway between a "vehicle" parody and a parody whose object is the parodied song itself, characterizing it for purposes of a full Lockean analysis would have to await a trial where the fact-finding process could explore the defendants' purpose in writing and performing the parody, and the purposes of the audiences who listen to it. ${ }^{386}$ One observation should be noted, however. It may be, as the circuit court suggests, that the song "is a comment on the banality of whitecentered popular music" but not a "direct comment" on the particular song at issue. ${ }^{387}$ Certainly the Orbison song seems to have had nowhere near the impact on the members or audience of 2 Live $\mathrm{Crew}^{388}$ that Disney had on those who drew or read the Air Pirates comic strips. But it may be unwise to draw the definition of influence or comment too narrowly. An entire genre can have an effect without any one work or copyright holder being dominant; if the proviso's protection is only triggered by the influence of truly major figures like Disney, artists and audiences affected by a genre could be left with no work in that genre to satirize, and no way to struggle with the genre's overall influence. This could leave them with less than "enough, and as good."

381. See the district court opinion at $754 \mathrm{~F}$. Supp. at 1154-55; the circuit court majority opinion at 972 F.2d at 1435-37; and the dissent by Judge Nelson at 972 F.2d at 1439, 1442-43.

382. Acuff-Rose Music, 972 F.2d at 1435 (footnote ommited).

383. Id. at 1435-36 n.8 (exploring the Sixth Circuit's "considerable reservation" concerning the district court's parody analysis).

384. Id. at 1437 (characterizing the district court's conclusion as one finding the song to be a "parody in the popular sense," presumably in contrast to what the circuit court earlier referred to as "the statutory definition of parody"). See id. at 1435 (distinguishing "popular" and "statutory" definitions of parody). There is, of course, no definition of "parody" in the copyright statute. What the Sixth Circuit had in mind by "statutory parody" was, apparently, "that which is necessary to create an exception to the exclusive rights in a copyrighted work." Id. at 1435.

385. The copyright statute itself directs courts to consider the "purpose" of the defendant's use, 17 U.S.C. $\$ 107$ (1988), and the fair use doctrine historically has been concerned with public benefit (i.e., audience purpose).

336. The case has only been heard on summary judgment.

387. 972 F.2d at 1436 n.8.

388. See id. at 1445 (Nelson, J. dissenting) (citing an affidavit "that the audiences for the two songs are quite different"). 


\section{E. The Pillsbury Dough Boy}

The issue again is a parody: an adult magazine, Screw, made plaster-ofparis replicas of the Pillsbury Dough Boy and, placing him in conjunction with his female equivalent, "Poppie Fresh," photographed the two replicas engaging in sexual activity (in so far as plaster-of-paris can so engage). ${ }^{389}$ The Dough Boy is both a copyrighted cartoon character and a trademark, and Pillsbury brought suit against the magazine under numerous theories including copyright, trademark, and the state "anti-dilution" statute..$^{390}$

In the discussion of the Gay Olympics case above, reference was made to new trademark theories that allow suit to be brought without need to prove consumer confusion. One such theory is "anti-dilution," under which several states have given trademark owners rights against even nonconfusing uses of their marks if the uses might dilute the marks' distinctiveness. The results generated by traditional theories can differ from those of the more propertarian "new" theories quite markedly, as is illustrated by the contest over the Dough Boy.

The Dough Boy court held that the parody was a "fair use" of the character so far as copyright law was concerned, citing the usual policies in favor of free expression. ${ }^{391}$ It also held there was no traditional trademark infringement despite the plaintiff's "concerted efforts to cultivate a respectable commercial reputation," ${ }^{392}$ because there was no appreciable likelihood of confusion. ${ }^{393}$ But then it held the magazine parody constituted actionable dilution of the Pillsbury trademark, and on that basis gave an injunction to the Dough Boy's owner. ${ }^{394}$

The magazine in the Dough Boy case apparently wanted to ridicule the wholesome image and anatomical incorrectness of the plump little figure, to restore for its readership a sense that sexual perceptions had a legitimate role to play despite the sanitized nature of commercial culture. Like the parody in Air Pirates, and for the same reasons, the magazine's parodic efforts should come within the protection of the proviso: the magazine needed access to the image to criticize its culture. Therefore, the Lockean analysis suggests that the "fair use" doctrine of permitting truthful reference to others' marks and symbols for purposes of communication must be part of any intellectual property doctrine, whether that doctrine is founded on a dilution rationale or otherwise.

389. Pillsbury Co. v. Milky Way Prods., 215 U.S.P.Q. (BNA) 124 (N.D. Ga. 1981).

390. The present statutory equivalent in the Georgia Code is O.C.G.A. $\S 10-1-451$ (b) (1989).

391. 215 U.S.P.Q. (BNA) at 129-32.

392. Id. at 134 .

393. Id. at 132-34.

394. Id. at 135. Plaintiff alleged defendant had "tarnished the reputation, and thereby impaired the effectiveness, of its advertising agents by placing them in a "depraved context." Id. The court gave relief on this claim "despite the lack of actual damages." Id. 


\section{CONCLUSION}

There are three potential doctrinal implications that might be drawn from this Article's analysis. First, the approach advocated here may persuade courts or legislatures to redefine and narrow intellectual property rights. My project, if successful, could therefore eliminate the need for the First Amendment in some instances. That is, my approach suggests that sometimes creators of intellectual products have no property that is justifiable by a natural rights or "desert" approach. If in such cases the primary basis of the plaintiff's asserted right is undermined, ${ }^{395}$ a defendant would not need to marshal the First Amendment to protect her free expression interests. She instead would be able to show that the plaintiff has no justifiable property interest to assert.

Second, under my theory sometimes the creator has a natural right to assert only if her remedy is limited to a damage-only recovery. That is, even if a plaintiff holds a qualified property right, that right-holder may be entitled to no more than liability rule protection. ${ }^{396}$ If courts or legislatures were to redefine available remedies accordingly, the First Amendment question of "prior restraint" need not arise in such cases-because, on property principles, the plaintiff would not be not entitled to obtain injunctive restraint against the defendant's activity.

Third, the approach presented could have some impact on the established jurisprudence of the First Amendment free speech cases. For example, if the courts are giving short shrift to the First Amendment in part because they think creators "deserve" complete exclusion rights, ${ }^{397}$ my approach should help courts recognize that plaintiffs can be said to "deserve" only a subset of the positive law rights they now claim. Similarly, another reason for the judiciary's unwillingness to use the First Amendment in these and other property cases may be the perception that insufficient state action is involved-sometimes courts seem to believe that in intellectual property cases they are merely acting as neutral enforcers of pre-legal natural rights. ${ }^{398} \mathrm{My}$ approach makes it clear

395. It is clear that natural rights are not the sole rationale for property rights under our legal system. Concerns about creating proper economic incentives also play a prominent role, as do other policies. This Article confines itself to exploring a particular natural-right justification for property.

396. See the discussion of liability rule protections in Part $\amalg(E)(1)$, supra (natural-rights rewards other than full property).

397. Another reason is the belief that doctrines within copyright, such as fair use and the "idea/expression dichotomy," fully accommodate the free speech interests. Fair use is defined supra note 11. "Idea/expression dichotomy" refers to the fact that copyright gives authors exclusive rights in their expression, but gives them no legal rights to prevent others from using their ideas.

398. This is of course more likely to occur in state law cases where the intellectual property right asserted has a common law basis. For copyright and patent the legislative origin of the right is obvious, although even in these statutory areas natural-rights arguments have appeared, particularly in the form of judicial suggestions that laborious efforts deserve reward. See, e.g., National Business Lists v. Dun \& Bradstreet, 552 F. Supp. 89, 92 (N.D. Ill. 1982) (copyright case); see also William W. Fisher III, Reconstructing the Fair Use Doctrine, 101 HARV. L. REV. 1659, 1688-89 (1988) (Discussing the argument that "authors and inventors deserve a reward for their labor and should be given it regardless of whether they would continue their work in the absence of such compensation."). It remains to be seen whether the 
that in most intellectual property cases where plaintiffs prevail in a conflict with speech rights, such results depend on governmental action in excess of what a natural rights claim would justify. Discrete governmental choices-an undeniable form of "state action"399-are necessarily involved. ${ }^{400}$ Also relevant to deciding collisions between the First Amendment and intellectual property is the strength of the audience interest at stake. If nothing else, this Article should serve to make more vivid the nature and importance of this too often underestimated interest, the liberty of each of us to manipulate symbols others have created.

But in a sense, any contribution to the law of the First Amendment is a byproduct. At the Article's core, its goal is to develop limits for intellectual property, and concomitant protections for expressive activity, that are internal to the definition of property rights themselves.

Our law is animated by more elements than those represented by a Lockean theory of natural right. In fact, one of the motivations for this Article was to help prune back the overweening growth in natural law rhetoric that has prompted many ill-conceived intellectual property decisions over the last two decades. ${ }^{401}$ But it remains to be specified what relationship should exist

Supreme Court will be successful in its recent effort to oust free-floating labor theory from the jurisprudence of copyright. See Feist Publications v. Rural Tel. Serv. Co., 1111 S. Ct. 1282, 1987-89 (1991) (denying copyright in telephone book white pages on ground that such an uncreative compilation, no matter how laboriously generated, contained no authorship).

399. It can also be argued that enforcement of "natural rights" is state action as well, but such an argument faces several additional layers of difficulty.

400. Enforcement of property rights should be acknowledged as state action. Admittedly, governmental power implementing the will of owners against nonowners is different from governmental power implementing the will of legislatures. That difference would properly have an impact on decided cases; not all forms of "state action" need be treated alike. But the difference is not enough to justify giving courts who create and implement ownership rights a complete immunity from existing substantive constraints on governmental power such as those found in the First and Fourteenth Amendments. See, e.g., David Strauss, Discriminatory Intent and the Taming of Brown, 56 U. CHI. L. REV. 935, 966-90 (1968). The Supreme Court seemed to recognize this in two famous cases that applied the Constitution to constrain judicial enforcement of "private" rights. Shelley v. Kraemer, 334 U.S. 1 (1948) (judicial enforcement of restrictive racial covenant on privately-owned property held subject to Fourteenth Amendment); New York Times v. Sullivan, 376 U.S. 254 (1964) (judicial enforcement of an individual's defamation claim held subject to the Fourteenth Amendment and, through it, the First Amendment). Today, however, only Sullivan can be cited without caveat, while Shelley's authority is uncertain. See, e.g., Strauss, supra, at 966-90 (defending the coherence of Shelley). Shelley's apparent fall from grace potentially undermines assertions that the Bill of Rights should constrain courts that enforce property rights.

Commentators who like Sullivan and dislike Shelley commonly try to distinguish the two cases by arguing that the state role in defining actionable defamation is greater (and is thus more properly subject to constitutional requirements) than is the state role in defining property rights in land. That line of argument should have been promising for intellectual products. Since the governmental role in creating intellectual property is usually quite obvious-consider for example the existence of, and many amendments to, the copyright and patent acts-one would imagine that copyright and similar cases would fall on the Sullivan side of the line, where it is uncontroversial to impose constitutional constraints. But though courts appear less concerned with "state action" when intellectual rather than tangible property is at issue, Sullivan's infusion of the First Amendment into tort law has still not played much role in intellectual property infringement suits.

401. This influence has been particularly strong in the tort known as "misappropriation"; for a critical examination of these and other doctrinal expressions of the principle that one should never "reap without sowing," see generally Gordon, On Owning Information, supra note 10. 
between natural rights arguments and the various other norms our law appropriately recognizes, particularly economic or utilitarian consequentialism. (Economic analysis is particularly important for intellectual products, because their public-goods nature creates difficulties for creators' incentives.) This Article cannot, of course, embark on a full exploration of that terrain. But a few observations can be offered.

Current intellectual property systems give rights in excess of what a Lockean model would justify. For example, American patent law gives a patentee exclusive rights enabling her to prohibit persons who independently invent the same thing from using the product of their own labors. Such an expansive set of rights, clearly not justified by a Lockean system, ${ }^{402}$ can only be justified by reference to norms other than natural rights. Similarly, copyright law gives authors rights over the "derivative works" that others make by building on their creations. ${ }^{403}$ To be justified under a Lockean notion of labor, ${ }^{404}$ the derivative work right would have to be quite narrow, giving an initial creator control over only those new works by others that significantly interfere with her own plans for the work. ${ }^{405}$ Yet current copyright law is not so limited; authors are entitled to control derivative works that they did not anticipate and that do not interfere with their own plans. If such legal rights, not justified by natural law, impose a net harm on the public, the natural law right against unjustified harm might well condemn them. For such legal rights to be justified, therefore, a cost-benefit analysis would have to show that they represent a net benefit to society. To the extent these doctrines produce net positive economic results for the public, they can be justified, at least to the extent that they do not infringe any of the public's nonfungible interests.

Even more clearly, the public is owed compensation if courts or legislatures violate the proviso ${ }^{406}$ by creating private rights that impair the public's access to the common. As discussed above, the common is a species of property. ${ }^{407}$ And as the Takings Clause of the Constitution's Fifth Amendment indicates, when government takes property, it should pay. What is true for private property should be true for public property as well. When the government infringes the public's natural rights, it should pay compensation. Intellectual property law can be crafted to do precisely this. The legislature and the judiciary can ensure that they grant rights that infringe some

402. See supra Part II(F)(2) (Lockean system justifies giving rights only against copying and not against independent recreation of the laborer's product).

403. 17 U.S.C. $\$ 106(1988)$.

404. See supra Parts II(B)(1) \& (2).

405. See supra Part II(B)(1).

406. Our copyright law awards copyright to any original work of authorship fixed in a tangible medium of expression, and does not require that a creator leave "enough, and as good" behind for others. Originality (even coupled with fixation) is not sufficient to guarantee that the proviso will be satisfied. See supra Part II(D).

407. See supra Part $\mathrm{II}(\mathrm{C})(4)$. 
fungible interest safeguarded by the proviso only when the law also gives the public compensatory benefits, particularly in terms of providing incentives. Thus, although the natural-rights approach is usually thought to be inconsistent with a public-benefits approach to intellectual property, ${ }^{408}$ it in fact supports a demand that significant components of intellectual property law be crafted to serve the public benefit.

As far as the proviso-protected interest in free speech is concerned, however, compensation is an unsatisfactory "second best." This aspect of the common is not fungible with pure economic benefit. Where it is impaired, therefore, economic incentives produced by an intellectual property system would give less than "just" compensation. If legislatures and judges would refuse to create intellectual property rights that violate the proviso, then, whether or not the courts recognize the First Amendment as an independent constraint on their grants of property rights, a substantial protection for creative liberty would result.

408. Cf. Howard Abrams, The Historic Foundation of American Copyright Law: Exploding the Myth of Common Law Copyright, 29 WAYNE L. REV. 1119, 1134 (1983) (arguing that copyright must serve the public benefit because authors lack common law rights that would independently entitle them to protection from copying). 
